\title{
European Journal of Economics and Management Sciences
}

№ 32019 


\section{European Journal of Economics and Management Sciences Scientific journal №3 2019}

ISSN $2310-5690$

\begin{abstract}
Editor-in-chief
Jovanović Milka, Croatia, Doctor of Economics

International editorial board

Adieva Aynura Abduzhalalovna, Kyrgyzstan, Doctor of Economics Bersirova Saida Halidovna, Russia, Ph.D. of Economics Biró Róbert, Hungary, Doctor of Economics Blahun Ivan Semenovich, Ukraine, Doctor of Economics Bogolib Tatiana Maksimovna, Ukraine, Doctor of Economics Chechelashvili Maya Yurevna, Georgia, Doctor of Economics Cherniavska Olena, Ukraine, Doctor of Economics

Ciobanu Marius, Romania, Doctor of Economics Dovgal Elena Andreevna, Ukraine, Doctor of Economics Ischuk Svetlana Alexeevna, Ukraine, Doctor of Economics Guliyev Igbal Adil ogly, Russia, Doctor of Economics George Chiladze, Georgia, Doctor of Economics, Doctor of Law Karanina Elena Valerevna, Russia, Doctor of Economics Kestutis Peleckis, Lithuania, Doctor of Economics Khubaev Georgy Nikolaevich, Russia, Doctor of Economics Khoutyz Zaur, Russia, Doctor of Economics Kocherbaeva Aynura Anatolevna, Kyrgyzstan, Doctor of Economics Kunditskyy Alexander Alexandrovich, Ukraine, Doctor of Economics Kurbanov Tohirdzhon Hakimovich, Russia, Doctor of Economics Meymanov Bakyt Kattoevich, Kazakhstan, Doctor of Economics Mizanbekova Salima Kaspievna, Kazakhstan, Doctor of Economics
\end{abstract}

Morozova Natalay Ivanovna, Russia, Doctor of Economics Navruzzoda Bakhtiyor, Tajikistan, Doctor of Economics Olgerta Visi, Albania, Doctor of Economics

Osmonkulova Guldana, Kyrgyzstan, Doctor of Economics Perova Margarita Borisovna, Russia, Doctor of Economics

Pshuk Bogdan Ivanovich, Ukraine, Doctor of Economics Rodionov Alexandr Vladimirovich, Russia, Doctor of Economics Salaev Sanatbek Komiljanovich, Uzbekistan, Doctor of Economics Saif Ulamin, Pakistan, Doctor of Economics Shamsiev Kamariddin Badrievich, Tajikistan, Doctor of Economics Sharko Margarita, Ukraine, Doctor of Economics Stahanov Dmitriy Viktorovich, Russia, Ph.D. of Economics Yakovleva-Chernysheva Anna Yurevna, Russia, Doctor of Economics Zelenskaya Tatiana Vasilevna, Russia, Doctor of Economics

Proofreading

Cover design

Additional design

Editorial office

E-mail:

Homepage:
Kristin Theissen

Andreas Vogel

Stephan Friedman

Premier Publishing s.r.o. Praha 8 Karlín, Lyčkovo nám. 508/7, PSČ 18600

pub@ppublishing.org

ppublishing.org

European Journal of Economics and Management Sciences is an international, German/English/Russian language, peer-reviewed journal. It is published bimonthly with circulation of 1000 copies.

The decisive criterion for accepting a manuscript for publication is scientific quality. All research articles published in this journal have undergone a rigorous peer review. Based on initial screening by the editors, each paper is anonymized and reviewed by at least two anonymous referees. Recommending the articles for publishing, the reviewers confirm that in their opinion the submitted article contains important or new scientific results.

Premier Publishing s.r.o. is not responsible for the stylistic content of the article. The responsibility for the stylistic content lies on an author of an article. Instructions for authors

Full instructions for manuscript preparation and submission can be found through the Premier Publishing s.r.o. home page at: http://ppublishing.org.

\section{Material disclaimer}

The opinions expressed in the conference proceedings do not necessarily reflect those of the Premier Publishing s.r.o., the editor, the editorial board, or the organization to which the authors are affiliated.

Premier Publishing s.r.o. is not responsible for the stylistic content of the article. The responsibility for the stylistic content lies on an author of an article. Included to the open access repositories:

\section{Google elibrary.RU (1) ULRICHSWEB' YBASERA

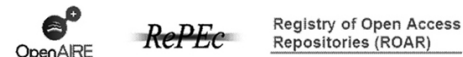 5) WorldCat} GLOalimpact Factor

(C) Premier Publishing s.r.o.

All rights reserved; no part of this publication may be reproduced, stored in a retrieval system, or transmitted in any form or by any means, electronic, mechanical, photocopying, recording, or otherwise, without prior written permission of the Publisher.

Typeset in Berling by Ziegler Buchdruckerei, Linz, Austria.

Printed by Premier Publishing s.r.o., Vienna, Austria on acid-free paper. 


\title{
Section 1. Marketing
}

\author{
Xueyi Rui, \\ Master in tourism management, \\ the School of management \\ Queens university of Belfast, \\ Minzu university of China \\ E-mail:xrui01@qub.ac.uk
}

\section{SERVICE MARKETING RESEARCH BASED ON SOSTAC STRUCTURE -BELFAST ZOO}

\begin{abstract}
Keywords: SOSTAC, tourist attractions, 8P, PESTEL.

\section{Situation}

\subsection{The Audit}

\subsubsection{Marketing environment}

Using PESTEL model to assess the macro environment of the Zoo.

\section{Political}

Co-operation between Belfast Zoo and other European zoos will be harder after Brexit because of increased bureaucracy between the UK and Europe and lack of established systems. In addition, the attitudes of global connection towards president Trump make it difficult for zoos and animal institutes to share information and animals from America.
\end{abstract}

Abstract. Belfast Zoo is one of the top fee-paying visitor attractions in Northern Ireland. However, the attraction of the zoo to tourists and potential tourists is gradually declining. The SOSTAC structure is used to analyze the zoo and external environment, some suggestions are concluded based on the analysis.

\section{Economic}

Belfast Zoo is funded by Belfast City Council which is devoted to developing business and investment across the city. According to Belfast city council financial accounting 2018, the total council reserves has increased $\mathfrak{£ 6 . 5 7 3 . 9 0 5}$ in 2018 , means the zoo might receive more allocations from City Council.

\section{Social}

The birth live of Northern Ireland has been decreasing for 10 years, which means the major customers of the zoo, children, is decreasing.

Besides, there are criticizes from social societies, claiming that it is unethical of zoos to exploit animals. A UK-based research found that $54 \%$ of elephants showed stereotypies (behavioural problems) during the daytime. However, Wickins-Dražilová $[17,27-36]$ argued that as long as zoos guarantee the welfare of their animals, it can be ethically justified to keep animals in zoo as they provide beneficial activities to the people of Northern Ireland such as Education and Science. As results, children have the access to learn how to respect and care for animals, allowing people to gain an insight into the natural world as well.

\section{Technology}

Belfast Zoo is still using traditional methods to feed animals. Many of the facilities on site are outdated and in need of repair or renovation. A computer system could be set up to help zoo keepers manage 
and maintain animals, allowing them to automate a number of management tasks within the site. The keepers time been saved can be used to attend to more important activities within the zoo and spend time on other customer focused programs.

\section{Environment}

Northern Ireland, surrounded by the Atlantic Ocean and Gulf Stream, has comfortable summers and temperate winters. The mild climate is suitable for plants growing, creating a suitable environment for a large number of animal species.

\section{Legal}

The legal environment for Belfast Zoo is not expected to change significantly. The rules of zoos are based on Zoo Licensing Act 1981 for years. With more supervising rules, such as Secretary of State's Standards of Modern Zoo Practice, Belfast Zoo should pay attention to maintaining a high level of health and safety within the attractions that involve interaction between customers and animals.

\subsubsection{Industry \& competitors}

Using Porter's five forces model to analyse competition of the zoo.

\section{Threat of new Entrants}

Organizations within the tourism industry require large sums of capital to begin operations and the barriers to entry this industry are significantly high. As the only zoo in Northern Ireland, Belfast Zoo can take the advantage of the lack of competition within the geography of Northern Ireland to generate higher revenue.

\section{Threat of Substitutes}

However, Belfast Zoo can lose customer to other more attractive interests within NI. For example, customers can easily be attracted to other tourist sites such as the Giants Causeway, Titanic Belfast or go on a tour of the Game of Thrones filming locations and potential profits can be taken away. It is shown in the survey from VisitEngland (Visitor Attraction Trends in England 2017, 2018) that zoos are less attractive to tourists compared to other attraction.

In addition, Children dictate how most families spend their family time and sometimes children are more attracted to other forms of entertainment. Thus, sports game or children's entertainment, can be a potential financial threat to Belfast Zoo.

\section{Bargaining power of customers}

According to market research from Belfast Council (2015), 86\% of visitors to Belfast Zoo are from the local area. Thus, the zoo should concentration more attention to catering towards local residents. On the other hand, it shows that Belfast Zoo has a huge potential customer base of foreign visitors that remains un-taped.

\section{Bargaining power of customers}

According to market research from Belfast Council (2015), 86\% of visitors to Belfast Zoo are from the local area. Thus the zoo should concentration more attention to catering towards local residents. On the other hand, it shows that Belfast Zoo has a huge potential customer base of foreign visitors that remains un-taped.

Regular visitors make up a large percentage of Belfast Zoo's visitors, suggesting that taking advantage of this to build an emotional connection with the visitors can increase the number of repeat customers to Belfast Zoo.

However, for the tourists from other areas, Belfast Zoo is far from their first choice. In Google Maps, "Visiting Belfast Zoo" is the twelfth thing recommended to do. It also cannot be found in the Ulster Bucket List: 18 FANTASTIC places to see before you die.

In a way, Belfast is in a weak place bargaining with visitors. Nevertheless, it can be overcome by tightening the emotional connection with visitors.

\section{Bargaining power of suppliers}

As animal trade is not encouraged in any way $[3,115-124]$, the suppliers of Belfast Zoo can only be the food retailer or machine factories.

Zoos are easily to have the access to food for animals, part from the outdoor environment in the zoo, part from the big suppliers for meat, vegetables and fruits. There are multiple choices for zoos with the huge demand, thus the suppliers do not have much bargaining power. 


\section{Industry rivalry}

There is only one zoo in the Northern Ireland, and the closest one is Dublin Zoo, which charges twice the ticket price of Belfast Zoo. For the citizens of Northern Ireland, most will not choose to take the extra 99.7 miles' drive to spend their family time at Dublin Zoo. However, for visitors from other areas outside of Ireland, who have already visited other Zoos like London
Zoo or Chester Zoo, they would not choose to visit a small scale one such as Belfast Zoo.

In conclusion, Belfast Zoo is relatively competitive within NI, but not within the UK.

\subsubsection{Belfast Zoo}

Using SWOT model to analyse the zoo itself.

Table 1 shows the internal and external factors affecting the market opportunities for Belfast Zoo.

Table 1. - SWOT analysis for Belfast Zoo

\begin{tabular}{|c|c|c|}
\hline & $\begin{array}{l}\text { Strengths: } \\
\text { a long running history rich experi- } \\
\text { ence only zoo in NI beautiful and } \\
\text { sustainable environment. }\end{array}$ & $\begin{array}{l}\text { Weaknesses: } \\
\text { Old fashioned facility. small acre- } \\
\text { age limited species } \\
\text { Backward concept of management. }\end{array}$ \\
\hline $\begin{array}{l}\text { Opportunity: } \\
\text { the development of big-data } \\
\text { wide use of social media } \\
\text { awareness of improve by pro- } \\
\text { motional activities }\end{array}$ & $\begin{array}{l}\text { SO: } \\
\text { applying experience into big-data } \\
\text { technology using historical data to } \\
\text { analyze user preference take advan- } \\
\text { tage of its uniqueness, holding zoo } \\
\text { activities }\end{array}$ & $\begin{array}{l}\text { WO: } \\
\text { attract more visitors by exchanging } \\
\text { animals with other zoos } \\
\text { low cost of improving facilities } \\
\text { easy to maintain environment }\end{array}$ \\
\hline $\begin{array}{l}\text { Threat: } \\
\text { lack of funds } \\
\text { other entertainment places in } \\
\text { Belfast }\end{array}$ & $\begin{array}{l}\text { ST: } \\
\text { No attractions nearby } \\
\text { No sufficient funds to maintain } \\
\text { historical buildings }\end{array}$ & $\begin{array}{l}\text { WT: } \\
\text { risk of bankruptcy } \\
\text { not appealing to tourists }\end{array}$ \\
\hline
\end{tabular}

\subsection{Key Issues, challenges and opportunities}

The most positive point of Belfast Zoo is the unique monopoly within the animal entertainment industry of Northern Ireland. However, with the decline of birth rate of Northern Ireland and the development of other interests, it will be hard for Belfast Zoo to attract visitors from local area and outside. In addition, because of the huge financial losses to the zoo, it is a big challenge for the zoo to obtain new equipment and construct new high-tech facilities. Last but not least, homogeneity competition from England is also a big threat to Belfast Zoo.

Considering all the pros and cons stated above, Belfast Zoo can grasp the opportunity to host fun activities to increase the visitor retention.

\section{Objectives: strategic focus and plan \\ 2.1 Strategic focus}

Using e-marketing methods and data analysing technology to increase the competitive edge of Bel- fast Zoo in attracting both local visitors and overseas visitors, resulting in higher revenue for Belfast Zoo. Stated by Hysni [ 8 , 3-5], electronic marketing is the most efficient methods of business nowadays which can bring multiple and unique marketing benefits including low-cost distribution.

The "Internet plus" strategy attempts to use the progress of modern science and technology to promote and enhance the development capacity of traditional industries $[9,78-81]$. Thus, a competitive organization has the desire to translate its business objectives and strategies into e-marketing goals and executable strategies to develop their business [16, 35-40].

In short period of time, Belfast Zoo cannot afford a huge amount of investment for facilities, while increasing the budget for hosting activities that can increase the Zoo's revenue and profits.

In the long term, raising competitive power of Belfast Zoo and making the zoo become one of the 
"have to do" things in Belfast, which would drastically increase the zoo's sustainability and popularity.

As for the expected financial performance, the zoo would hope to get a $30 \%$ increase of the revenue until 2020 , break even in 2022, make 30\% profit in 2025 .

\subsection{Plan}

\subsubsection{Using e-marketing strategy}

Hosting interesting competitions and activities online to attract people joining in. As a result, the popularity of Belfast Zoo among people of Northern Ireland will increased greatly.

\subsubsection{Using word-of-mouth advertising method}

Word of mouth is the most efficient method in convincing customers to attend the zoo because of its experiential nature. It is also estimated that about $20 \%$ to $50 \%$ of consumer decisions are based on word of mouth as the primary factor to convince people to consume a product $[2,113-116]$.

\section{Strategy}

\subsection{Segmentation}

Considering the average wages of NI, i.e. about $£ 525$ per week, residents have the ability to afford the costs of touring Belfast Zoo. However, rich families have many other options to enhance family's affection than visiting Belfast Zoo compared with middle class. Thus, we are going to target to families with children between 2 to 13 years old who is tend to revisit more than once. Besides this, there will be also some activities suitable for adults who is 18 to 30 years old, has the financial ability to afford higher price activities with a salary above the average level.

\subsection{Targeting}

\subsubsection{Local visitors}

Encourage visitors share their experiences with friends

1. Holding international activities to spread word-of-mouth advertising, for instance, a photo competition, story-telling competition and competition of "the most efficient plan for visiting the zoo" on social media. A year-round ticket or free food can be offered to winners.
2. Set up a small message board in the entrance of zoo, allowing people express their feeling after visiting. For example, children can draw a picture of their favourite animals, or leave a message about café.

Build emotional connection with visitors

1. Hosting activities such as "show your old photo in the zoo" in social media, reminding people of their cherished memories of Belfast Zoo.

2. Create a culture of "birthday tradition" where customers decide to visit the zoo on their birthday. People will form a habit of visiting the zoo on their birthday, thus increasing the zoo revenue.

3. Test what kind of animal are you belong to: putting visitors' character data into our data-analysing website, matching one specific animal in the zoo who sharing similar features.

\section{2 visitors from outside of $\mathrm{NI}$}

1. Foreign visitors can sign up to a package that allows them to receive regulate updates about and animal they chose to support (e.g. providing halfyear, monthly mailing postcard service with animals' photos). And ask them for further donations to protect the endangered species.

2. Have the change to pet animals through special activities for adults which allow people get a deep, thoroughly understanding of animals they are interested in in a two-day camp.

3. Create an online app that allows users to input their personal traits and match them with an animal that reflects their personality, that currently resides within the zoo. So the user can then purchase a ticket to go and visit Belfast Zoo. The data collected can then be used to analyse the behaviour of this marketing strategy.

\section{3 positioning}

As the Positioning Map shown below, Belfast Zoo has a relatively low price of ticket but with a median high-level service. As for the analysis above, the main factor driven people to visit attractions is the high-quality family time they shared. Considering such purpose, Belfast Zoo is more competitive than movies because parents cannot react physically 
with children. Besides, a lower price with almost the same quality, Belfast Zoo is more attractive to middle-income families.

To sum up, a tourism position of low price but relatively high quality can be very attractive to visitors.

\section{Tactics}

According to Kotler [10, 357-362], by transforming the marketing action, the marketing program can build customer relationships. The marketing strategy includes marketing mix that is a set of marketing tools that companies use to implement their marketing strategies. The purchasing decisions made by consumers will be influenced by marketing mix. Kotler and Amstrong argued that companies use the marketing mix as a set of tools for its marketing objectives. The 7P marketing mix is to incorporate in a rapidly developing marketing system, i.e., product, place, price, promotion, physical evidence, people, and process. Now the scholars have added partners, which is 8P's. Based on the marketing strategy above, the 8P's for Belfast Zoo can be summarized as follows:

\subsection{Product and Service}

The product and service are generally considered as the first element of mixed marketing. Belfast Zoo provides leisure and recreation activities to its customers, by displaying and educating their customers about the animals. Belfast Zoo uses storytelling as a technique to educate its customers about the habits and behaviors of the animals, that attract customers. Storytelling is such an important tool that is pervasive through our life. The traditional style of zoo is less entertaining for the customer, to improve this, we can provide more for-profit and non-profit activities. For example, during the penguins feeding time, visitors can buy fish from the keepers and feed the penguins themselves. The money will be used to protect the endangered penguins and improve the quality of life of the zoo's penguins. To develop the zoo, we can involve children in activities that education the children and bring them closer to nature. Moreover, by showing films about animals, you can either generate income or enrich tourists' experience while at the zoo.

As zoos are aware of the significance of ensuring the survival of threatened and endangered species, the focus of zoos have shifted to conservation since the 1960s. There are more than 130 endangered species at Belfast Zoo of which the majority of these animals are facing increasing danger in their natural habitats. Many of these species are now living in Belfast Zoo under endangered species programs. Promoting animal protection awareness and raising people's environmental awareness is also one of the zoo's non-profit activities.

\subsection{Price}

Price is highly important as one of the marketing elements. We can clearly see the price of Belfast Zoo from its website, there are many types of Belfast Zoo tickets and tickets of donation type can be purchased to donate money to local, regional and international conservation projects.

On top of that, Belfast Zoo also offers membership and annual tickets, which, unlike one-off ticket sales, membership systems allow visitors to generate more consistent source of income for the zoo in the long run. Attention should be paid to the cost of developing products, services and their maintenance costs over time. While also considering how much the customer will pay. We could add some valueadded services in the ticket price, such as increasing the price of the little train in the zoo for children or include a meal in the zoo restaurant.

\subsection{People}

The staff at Belfast Zoo are enthusiastic and knowledgeable, but the proportion of staff is disproportionate. Systematic marketing research should be conducted to make a blueprint of services and standardize as many components of it as possible to institute a formal, ongoing process for setting service specifications. At the entrance to Belfast Zoo, there is a display board showing the outstanding staff of 2017 this rewarded employee who displayed superior customer service. The man- 
ager of Belfast Zoo should support employees with appropriate technology and information systems to reduce role conflict and role ambiguity among customer-contact employees. On the other hand, Regular staff training will ensure the staff will be more reliable, responsive, assuring, empathic.

\subsection{Process}

In the case of 'high-contact' services, where customers are involved in the process. Belfast Zoo did a good job of providing information on the sign, to allow customers to navigate the zoo. Tourists can clearly see the map at the entrance and at any location in the zoo Furthermore, through the zoo website publicity, the visitors can have more channels to learn about the different activities of the zoo and the situation of animals.

However, according to Ulster Unionist councilor, only $8 \%$ of the visitors are from outside Belfast. So, actions should be taken to attract more people from other cities. The park can set up shuttle buses every weekend to pick up tourists from the downtown of the nearby city. Tour guides can teach the tourists about the zoo and its animals before they arrive and run competitive quizzes, allowing the tourist to win prizes. The zoo can promote a package deal for the customer that includes travel, ticket price and food. This will increase the added value of the ticket.

\subsection{Physical evidence}

Physical evidence is very important because consumers use tangible clues to make assessments of the quality of service provided. Hence, the more intangible-dominant a service is, the greater the need to make the service tangible. Belfast Zoo uses display card to introduce the name, food, habitat, distribution, degree of danger and other information of these species. There are also special placards for newly born animals, including the name and the individual, the date of birth of these species. There are also some warnings to visitors not to feed the animals and to keep quiet. These exhibition signs are playing the role of science popularization, publicity and warning. However, the logo of Belfast Zoo is not so attractive. A good logo can quickly attract consumers and create brand effect. As a logo of a zoo, the logo can use Anthropomorphism. Anthropomorphism allows consumers the opportunity to interpret a broad range of products in terms of their most familiar framework: their own humanity [4]. Branding semiotics is of great significance that it enable the development of iconic brands that can easily be recognized and identified by a simple logo, sign, or even color by everyone [13, 81-92].

We can also apply the Intelligent travel into Belfast Zoo. The use of electronic display can extend the life of display cards, on the other hand this can enhance the vitality of display cards also. Belfast Zoo can provide positioning device feedback system for tourists. Through this system, the dynamic of tourists can be monitored in real time, and the appropriate tour route can be recommended according to the actual situation of tourists, to provide more convenient services for tourists.

\subsection{Placement}

A multi-channel customer management as the design, deployment, coordination, and evaluation of channels to enhance customer value through effective customer acquisition, retention, and development [14, 204-211]. Belfast Zoo does not use many channels to promote itself. We can hold some animal photography competitions with prizes and display these photos in the city of Belfast and near some children's parks. According to research done by the zoo, more than two fifths (44\%) of all visitors were most likely to have been influenced to visit the zoo by children. We can start from this point, expand channels to attract different types of customer groups, such as the leisure and recreation theme to attract busy white-collar workers. Hosting camping activities, where customers can interact with herbivores, to attract more animal lovers and adventurers.

\subsection{Promotion}

Belfast Zoo does not do well in promotion. We can promote Belfast Zoo through the follow- 
ing marketing methods. First, personal Word-ofmouth (WOM) which is Person-to-person communication between a receiver and a source whom the receiver perceives as non-commercial, regarding a product, service or brand. If we can create an unforgettable experience for the consumers, they will become our free propagandists. Zoos can invite web celebrities to visit, feed animals and go camping, and encourage them to post on Instagram or twitter to promote the zoo. this is leader marketing which is known as a marketing company pays an actor or socially adept person (opinion leader) to use a product visibly and convincingly in locations where target consumers congregate. Belfast Zoo is mostly mentioned by twitter; the zoo needs to maintain a good image not only on twitter but also on other channels.

\subsection{Partnership}

Tourism organizations can best achieve their goals when the joint activities of multiple Participants are conducted within a formal structure. Bramwell and Lane (2000, pp. 4-5) describe the attainment of mutual benefits through collaboration as "synergistic gains from sharing resources, risks, and rewards, and the prioritization of 'collaborative advantage' rather than individual 'competitive advantage'. Belfast Zoo should strengthen communication and cooperation with zoos in Britain and Ireland, for example implement a package ticket system or exchange rare animals to attract more tourists. Furthermore, animal experts from other zoos can be invited to give science lectures to attract more children to get close to nature.

\section{Actions}

According to a report in 2016, we can clearly see that Belfast Zoo lost more than a million pounds in 2015.We must take measures to reverse the loss of money from Belfast Zoo. Based on Tourism Life Cycle, "The life cycle is comprised of the following stages - an exploration stage. an involvement stage, a development stage. A consolidation stage, a stagnation stage and either a decline stage or rejuvenation stage."
Levitt [11,81-94] proposed there are four possible suggestions: Promoting more frequent use among current tourists; Developing more varied use among current tourists; Creating new tourists; Finding new tourists. Intelligence zoo and service marketing actions will be immediately applied to the zoo.

1) On the basis of increasing the number of animal species, it is necessary to build a distinctive zoo to create a special zoo brand; The zoo should expand its income source and open potential incomegenerating activities. It cannot rely solely on ticket income as a source;

2) The zoo needs to change the ticket marketing strategy so that visitors can visit the zoo in a sustainable way instead of one-time sales;

3) Promote the universal acceptance of the membership system and increase the welfare of members;

4) Increase the capacity of the zoo to allow the animals on display to behave naturally;

5) The zoo should actively participate in the meetings of the International Zoo Association, learn from and learn from foreign advanced management techniques.

\section{Evaluation and control}

Belfast Zoo's annual plans have been drawn up. The specific monthly plans will be determined according to the off-peak season for tourism. Comparing the actual marketing plan with the established marketing plan to determine a strategy that can be implemented in some specific situations. In the event of an accident, it is possible to follow the previous emergency response method and then bring the newly established strategy into it. The key points of establishing KPI indicators are flow, planning and systematization. Setting up 8 key performance indicators for the zoo, including quality performance, energy management of the zoo, cost performance, project profitability, energy consumption and resource conservation, health and safety, stakeholder satisfaction, innovation and improvement. 


\section{References:}

1. Beverland M., Lindgreen A., Napoli J., et al. Being known or being one of many: the need for brand management for business-to-business (B2B) companies [J]. Journal of business \& industrial marketing, 2007.

2. Bughin J., Doogan J., Vetvik O.J. A new way to measure word-of-mouth marketing [J]. Mc Kinsey Quarterly, 2010; 2: 113-116.

3. Butler R.W. The concept of a tourist area cycle of evolution: implications for management of resources [J]. Canadian Geographer / Le Géographe canadien, 1980; 24(1): 5-12.

4. Cuarón A. D. Further role of zoos in conservation: Monitoring wildlife use and the dilemma of receiving donated and confiscated animals [J]. Zoo Biology: Published in affiliation with the American Zoo and Aquarium Association, 2005; 24(2): 115-124.

5. Delbeare M. Personification in advertising: Using a visual metaphor to trigger anthropomorphism [J]. Journal of Advertising, 2011; 40(1): 121-130.

6. Espeland W.N., Sauder M. Rankings and reactivity: How public measures recreate social worlds [J]. American journal of sociology, 2007; 113(1): 1-40.

7. Frost R., Strauss J. E-Marketing.- New York: Routledge, 2013.

8. Harris M., Sherwin C. and Harris S., The welfare, housing and husbandry of elephants in UK zoos, 2008.

9. Hysni T. E-Marketing (Electronic Marketing) as a tool of communication with the customer. Journals of Advanced Scientific Research and Innovation 2017; 11(219318 11): 3-5.

10. Jungang C. Research on the construction of smart park based on "Internet +" [J]. Gardens. 2016; (9): $78-81$.

11. Low G. S., Fullerton R. A. Brands, brand management, and the brand manager system: A critical-historical evaluation [J]. Journal of marketing research, 1994; 31(2): 173-190.

12. Mueller A., Schade M. Symbols and place identity: A semiotic approach to internal place branding-case study Bremen (Germany) [J]. Journal of Place Management and Development, 2012; 5(1): 81-92.

13. Neslin S.A., Gupta S., Kamakura W., et al. Defection detection: Measuring and understanding the predictive accuracy of customer churn models [J]. Journal of marketing research, 2006.43 (2): 204-211.

14. Selin S. Developing a typology of sustainable tourism partnerships [J]. Journal of Sustainable tourism, 1999. 7(3-4): 260-273.

15. Sward D., Macarthur G. Making user experience a business strategy [C] // E. Law et al. (eds.), Proceedings of the Workshop on Towards a UX Manifesto. 2007; 3: 35-40.

16. Levitt T. 'Exploit the PLC', Harvard Business Review,- Vol. 43.- November-December 1965.- P. 81-94.

17. Wickins-Dražilová D. Zoo animal welfare $[\mathrm{J}]$. Journal of agricultural and environmental ethics, 2006; 19(1): 27-36. 


\title{
Section 2. Management
}

\author{
Chornyi Oleh, \\ Post-Doctoral Student (Economics), \\ the Management and Law Faculty \\ Vinnytsia National Agrarian University \\ E-mail:phd.chornyi@gmail.com
}

\section{IMPROVING INNOVATIONS: BETWEEN EU AND UKRAINE}

\begin{abstract}
The article contains some aspects related to the creation and development of innovations in the European Union. On the basis of the analyzed material, advices concerning the development of Ukrainian innovation system are provided.
\end{abstract}

Keywords: European Union, innovation policy, innovations, interdisciplinarity, national innovation system, Ukraine.

In the $21^{\text {st }}$ century, the importance of innovation, the multilevelness and the speed of implementation are important growth factors for both developed and emerging economies. The situation becomes even more understandable if we look at the role of innovations in the process of global civilization historical development. Transport (cars, trains, planes) and communications (telegraph, telephony, internet) are classic examples of innovation [9]. However, during the $20^{\text {th }}$ century, innovations were created in a much larger number of economy branches: aeronautics, national security, chemical industry and cosmetology, household goods, medicine, energy, computers and many others [6]. All of this indicates that the development and implementation of innovation has a strong interdisciplinary character. That is why, theory of innovations can be applied to the vast majority of national economy branches.

In this paper, we will focus attention on some peculiarities of innovations creation and implementation in the European Union [EU] (including those in the Eastern European countries), as well as the

possibility of using these lessons in Ukrainian realities (in particular industry or on specific enterprise).

Industrial modernization is an important issue in Europe, and therefore, at all levels, attention is drawn to practical aspects such as commercialization, business models and industrial use of innovations [4]. These components are particularly important, as within the EU, situation with innovations varies considerably between countries and regions [3]. The situation seems to be as following: large investments in innovations and research have a positive effect on the possibility of innovations implementation and on making profit at the expense of this. Some studies establish a positive direct correlation between public spending on research and national economic growth (a study was conducted over a 20-year period in 20 EU countries) [11]. In each case, there are two main factors associated with innovations: a cost of innovations and their production competitiveness [8]. It means that politicians, state administrators and governors should pay attention to the above mentioned problems, as well as guide and strategically justify economic growth 
in a country. Taking into account these features of innovations implementation will help to modernize the existing branches of the national economy. It will also strengthen creation of innovative clusters in numerous industries and increase competitiveness of enterprises at the regional level.

In general, Ukraine can increase the efficiency of the national innovation system at the expense of statics and policy making (these two factors have high level of efficiency in the EU today). Measures of innovation can have a very large scale and relate to 30 countries with a time span of 10 years [14]. Nonprice factors are also important, namely politics and law [14]. Facilitating procedures for innovations development and increasing their transparency greatly enhance the competitiveness of the national innovation system. These problems can reveal two types of interdisciplinarity, related to innovations. The first concerns the concept of innovation and is related to the theory and methodology of development, application and dissemination of innovations. The second, correlates with different branches of economy and manifests itself as the specificity of innovations creation in a particular industry (agriculture, education, medicine, etc.).

As already mentioned, the EU countries differ significantly in terms of competitiveness and innovation. Given the convergence that exists between EU countries and even their neighbors, Ukrainian politicians, business and academics should pay attention to the situation in Eastern European countries, which are members of the EU. Taking into account Ukraine's aspiration to become a member of the EU, it is necessary to admire the convergence between Ukraine and its neighbors. That is why we will consider the peculiarities of innovations development in countries such as Romania, Hungary, Poland and Slovakia. The literature is numerous, but we will focus on some specific aspects.

At the current stage of the national innovation system development, issues of the innovativeness improvement of areas within the country are very important in Romania [13]. As well as patent-licensing issues [10]. These two aspects are especially relevant for Ukraine, therefore, it is necessary to pay close attention to the experience of Romania in improving the innovativeness of certain areas and facilitate patent-licensing procedures.

Studies within Polish industry have established a positive correlation between creation of new products and human capital [16]. This means that an increase in human capital has a positive effect on the creation, implementation and dissemination of innovations. A similar problem is also relevant for Ukraine. Increasing of the average educational level of Ukrainian enterprises and institutions, and also people living standards can create additional positive conditions for innovativeness improvement of the national economy.

Ukraine should use examples even of small countries, their experience may be useful and productive. Thus, it has been found that in Slovakia, small and medium-sized enterprises play a key role in the transfer of innovations from the inventor to the market [5]. Such an example is particularly valuable for Ukraine, as numerous small and medium-sized enterprises could take over the burdens associated with the transfer of innovations. This situation is especially valuable given the large number of canted projects and patents contained in Ukrainian universities ( $R \& D$ projects, basic innovations, innovative models).

Another, vivid example of Hungary, may lead to the idea of innovations creation in each particular sector of a national economy. Taking as an example the Hungarian food industry, the authors draw conclusions about the impact of innovation on competitiveness and its relative level [5]. Today, we can say with certainty that there is a direct link between an innovation and a competitiveness of a particular industry branch.

Hence, if we take into consideration a specific case of Ukraine, we can look at the current situation from innovational point of view. First of all, there is 
a weak link between GDP dynamics and innovations in Ukraine [2]. This implies not only the relatively low level of the Ukrainian innovation system, but also the possibilities that can be used. We should use non-price improvements related to legislation, multiple policies and innovation management. For example, it is necessary to artificially create demand for innovations, to prepare innovations managers (also at universities), and to synchronize existing state innovation policy with educational, technological and industrial policies [1]. In addition, state financing of science remains the main factor [15]. The latter factor is extremely important for Ukraine, since in Europe it has a superior significance itself (see above). Finally, it's worth mention a systematic approach to understanding, creation and improvement of Ukrainian innovation system. Within specific industries, specialized clusters should be organized that will be more or less homogeneous, so innovations can gain superior attention.

Ukraine has numerous advantages in terms of various economy sectors reforming, through innovations creation. Even the backward and lucrative sectors of the economy can be greatly improved by increasing their innovative level. The formation of Ukraine's innovation system is a complex process, as
Ukraine has numerous industries. That is why, governors and policy makers in the field of innovations must use an interdisciplinary approach to avoid inappropriate simplifications and false reductions.

We can conclude, that a lot of opportunities associated with innovations exist today. Developing countries should create innovations faster in order to create convergence with developed countries. Once a national innovation system is created, a national economy can take part in global economic processes associated with innovations. In order to become innovative Ukraine must use experience of EU, especially neighboring countries. Examples of Hungary, Poland, Romania and even Slovakia can help to boost innovations in the country. Complex innovation policy must be supported by state departments, on one hand, and local authorities, on the other hand. In order to achieve rapid economic grows Ukraine must show willingness to improve innovativeness of the most economy branches. Creation of innovations within separate industry can reveal hidden potential and even restore competitiveness of unproductive enterprises. Reforms of the last five years show that improvements can be achieved, but they must be supported by governors. Ukrainian enterprises still need a lot of guidance and support.

\section{References:}

1. Fedulova L. Innovativeness of the economies of the EU and Ukraine: undertakings to narrow the gap. Economic Annals-XXI, 156(1-2), 2016.- P. 22-25.

2. Goliuk V. Impact of innovations on gdp dynamics. Marketing and management of innovations, 2, 2017.P. 151-159.

3. Hunady J., Pisar P., Musa H., \& Musova Z. Innovation support and economic development at the regional level: panel data evidence from Visegrad countries. Journal of International Studies, 10(3), 2017.- P. 147 160. Doi: $10.14254 / 2071-8330.2017 / 10-3 / 11$

4. Ivanová E., \& Kordoš M. Innovation policy of smes in Slovakia in the context of European union innovation policy. Marketing and management of innovations, 3, 2017.- P. 213-225.

5. Koišová E., Grmanová E., \& HabánikJ. Regional disparities in financing innovations in small and mediumsized enterprises. Journal of International Studies, 11(3), 2018.- P. 124-136. Doi:10.14254/2071$8330.2018 / 11-3 / 11$

6. Mamrayeva D., Stybaeyeva A., \& Tashenova L. The research of global innovation capital: a review and analytical comparison. Economic Annals-XXI, 167(9-10), 2017.- P. 4-7. 
7. Psychoyios D., \& Dotsis G. The Competitiveness of the European ICT Industry. Review of Economic Analysis, 10, 2018.- P. 97-119.

8. Sabatino M., \& Talamo G. Innovation and Competitiveness of European Regions. Research in Applied Economics, 9(3), 2017.- P. 45-69.

9. Sandal J.-U.Howinnovation maintains and develops democracy. Economic Annals-XXI (2017), 165(5-6), - P. 23-26.

10. Stanciu S. Aspects of Innovation and Technology Transfer in Romania. Valahian Journal of Economic Studies - Vol.9(2), 2018.- P. 95-108. Doi 10.2478/vjes-2018-0021

11. Szarowská I. Does public R\&D expenditure matter for economic growth? GMM approach. Journal of International Studies, 10(2), 2017.- P. 90-103. Doi:10.14254/2071-8330.2017/10-2/6

12. Torok A., Toth J., \& Balogh J. M. Networking theory of innovation in practice - The Hungarian case. Agricultural Economics, 64(12), 2018.- P. 536-545. URL:https://doi.org/10.17221/60/2018AGRICECON

13. Vaculík M., Pászto V., \& Švarcová B. Spatial distribution of innovation activities in Czech Republic, 20102012. Journal of International Studies, 10(1), 2017.- P. 123-134. Doi:10.14254/2071-8330.2017/10$1 / 8$

14. Włodarczyk J. Innovations and income inequalities - a comparative study. Journal of International Studies, 10(4), 2017.- P. 166-178. Doi:10.14254/2071-8330.2017/10-4/13

15. Zakharkina L., Myroshnychenko I., Smolennikov D., \& Pokhylko S. Efficiency of Innovation Activity Funding as the Driver of the State's National Economic Security. Montenegrin Journal of Economics, 14(4), 2018.- P. 159-173.

16. Zwolak J. Innovative undertakings in the Polish industry. Proceedings of Rijeka School of Economics, 34(1), 2016.- P. 147-160. Doi: 10.18045/zbefri.2016.1.147 


\title{
Section 3. World economy
}

\author{
Abdullaev Turgut Nizami, \\ doctoral student, Baku State University, Baku, Azerbaijan \\ E-mail: turqut.a.314@gmail.com
}

\section{PROSPECTS FOR COOPERATION BETWEEN THE ADB AND AZERBAIJAN TO ENSURE REGIONAL SECURITY}

\begin{abstract}
The article emphasizes the political and economic importance of the Asian Development Bank to ensure security in the region. The objectives and tasks assigned to the ADB and the problems it solves are considered. The $\mathrm{ADB}$ with special functions in long-term financing of socially significant projects contributes to economic growth, diversification and modernization of the economy, and the solution of environmental and social problems. Therefore, the article analyzes the participation of the $\mathrm{ADB}$ in the socio-economic development of the country. The article explored the characteristics of the activities of the $\mathrm{ADB}$ and the national interests of Azerbaijan. Outlines the leading position of Azerbaijan in the Caucasus. The analysis of the $\mathrm{ADB}$ and the AR is given to identify areas of investment attractiveness of Azerbaijan. Considered adopted program documents that ensure the stability of the economy of Azerbaijan during the years of reform. The necessity of cooperation with the $\mathrm{ADB}$ and making changes in the process of cooperation from the perspective of the national interests of Azerbaijan is considered. A brief description of the activities of the $\mathrm{ADB}$ in the Republic of Azerbaijan is given, taking into account the macroeconomic situation, the level of development of market mechanisms and government priorities. The Asian Development Bank provides funding for socially significant projects that contribute to the development of not only Azerbaijan, but also the entire region. In the course of the study, attention was drawn to the experience of the $\mathrm{ADB}$; the following were used: a logical generalization, methods of analysis and groupings. The article compares the spheres of interests of the ADB and the main directions of development of the national economy, its key sectors. The author has grouped the main directions of the activities of the $\mathrm{ADB}$ and the $\mathrm{AR}$ to ensure regional security, and as a result of the analyzes made, the main prerogatives in the partnership between the $\mathrm{ADB}$ and the AR have been identified.
\end{abstract}

Keywords: regional integration, national interests, security, project financing, cooperation.

Абдулиаев Тургут Низами, докторант, Бакинский Государственный Университет,

Баку, Азербайджан

E-mail:turqut.a.314@gmail.com

\section{ПЕРСПЕКТИВЫ СОТРУДНИЧЕСТВА АЗБР И АЗЕРБАЙДЖАНА ПО ОБЕСПЕЧЕНИЮ РЕГИОНАЛЬНОЙ БЕЗОПАСНОСТИ}

Аннотация. В статье подчеркивается политико-экономическое значение Азиатского Банка Развития по обеспечению безопасности в регионе. Рассматриваются цели и задачи поставленные 
переА АзБР и решаемые им проблемы. АзБР с особыми функциями по Аолгосрочному финансированию общественно значимых проектов способствует экономическому росту, Аиверсификации и модернизации экономики, решению экологических, социальных задач. Поэтому в статье анализируется участие АзБР в социально-экономическом развитии страны.

В статье исследованы особенности деятельности АзБР и национацьные интересы АзербайАжана. Излагается милирующая позиция Азербайджана на Кавказе. Аается анализ АзБР и АР Аля выявления направлений инвестиционной привлекатемьности Азербайджана. Рассматриваются принятые Аокументы программного характера, обеспечивающие экономике АР устойчивость за годы реформ. Рассматривается необходимость сотрудничества с АзБР и внесения изменений в процесс сотрудничества с позиции национальных интересов АР. Аается краткая характеристика Аеятельности АзБР в АзербайАжанской Республике, с учетом макроэкономической ситуации, уровня развития рыночных механизмов и правительственных приоритетов. ПосреАством Азиатского Банка Развития обеспечивается финансирование общественно значимых проектов, способствующих развитию не только АзербайАжана, но и всего региона.

В процессе исследования внимание было обращено на опыт АзБР, были использованы: могическое обобщение, методы анамиза и группировок. В статье сопоставляются сферы интересов АзБР и основные направления развития национальной экономики, ее ключевых отраслей.

Автором сгруппированы основные направления деятельности АзБР и АР по обеспечению региональной безопасности, в результате сАеланных анализов выявлены основные прерогативы в партнерских отношениях межАу АзБР и АР.

Кмючевые слова: региональная интеграция, национацьные интересы, безопасность, финансирование проектов, сотрудничество.

\section{Введение}

Несмотря на то, что АзербайАжан находится в регионе с неразрешенными территориальными конфмиктами, такие как Нагорный-Карабах, Абхазия и Южная Осетия, все же имеет существенное значение Аля мировой экономической системы, что обусловлено возможностью транзита прироАных ресурсов и стратегически значимых товаров как из АТР в Европу, так и обратно. Но на Аанный момент существует ряд негативных аспектов на Южном Кавказе, которые влияют на региональную безопасность и к ним относятся:

- нестабильная обстановка на минии прикосновения Азербайджана и Армении несмотря на то, что в 1994 году быи поАписан Бишкекский договор о прекращении огня;

- конфронтация межАу Грузией и Абхазией, Южной Осетией;
- милитаризация и наращивание военного потенциала стран региона;

- ухудшение отношений сосеАних стран с Аругими странами, в частности Ирана, России со странами Западной Европы и США, примененные ограничительные санкции против Ирана и России;

- существующий и косвенно влияющие опасности межАународного терроризма, экстремизма и нестабильной политической обстановки, наркобизнеса, организованной преступности, экомогические катаклизмы и проблемы межэтнического, религиозного характера.

Меняющийся глобальный и региональный экономический манАшафт раскрыл развивающиеся экономики с частым макроэкономическим потрясением. Ограниченные Аанные и Аругие ограничения препятствуют надежному кратко- 
срочному макроэкономическому прогнозированию и затрудняют выбор наиболее эффективных инструментов политики Аля содействия макроэкономической стабильности и устойчивого роста.

Научно-практическая значимость исслеАования

В Азиатско-Тихоокеанском регионе произошло значительное увеличение числа беАствий вызванные стихийными катаклизмами, такими как наводнения, тайфуны и циклоны, засуха, землетрясения, извержения вулканов и цунами - от 400 в 1970-х годах до более чем 1100 в 2010 -го года. В 2017 году ущерб от стихийных беАствий составил около 35 милмионов Аолларов. Что касается изменения климата, углекислый газ явмяется основным источником выбросов парниковых газов. Только АзербайАжан выбросили 5 тонн на душу населения в 2010 году. Стихийные беАствия и климатические изменения угрожают региону в обеспечении Аолгосрочной устойчивости и развитии. Потому необходимы согласованные усилия Амя разработки политики и установить системы безопасности Аля реагирования на растущие угрозы от природных опасностей. Это подчеркивает необходимость современных исследований и всестороннего анализа, развивающихся макроэкономические события и проблемы, затрагивающие регион, и, в частности, примеры кучшие практики из Аругих стран. Как указано в Стратегии АзБР Ао 2030 года, актуальность АзБР будет все больше зависит от его роли в качестве института знаний, и особенно от его активной роли в исследование. Знания и научно обоснованные исследования АзБР играют ключевую роль в повышении понимания критических областей Аля Аействий, поААержки хорошей политики и реформ в развивающихся странах, они явмяются добавлением к глобальным обсуждениям развития, предлагая перспективы избавления проблем региона. ЗаАача правительства по развитию экономики, основанной на знаниях, требует квалифицированные навыки и передовые информационные и комму- никационные технологии в правительстве и бизнесе. Правительство при содействии партнеров по развитию, таких как Всемирный Банк, Аетский фонА ООН (ЮНИСЕФ), Агентство США по межАународному развитию и EximBank Кореи укрепляют систему образования, чтобы укучшить качество знаний и навыков выпускников. Правительство также вкладывает значительные среАства модернизировать коммуникационные и информационные технологии в совершенствовании государственных ускуг. АзБР, спонсируя развитие современной инфраструктуры созАает благоприятные условия Амя инноваций, инвестиций в науку, технологии и исследования и облегчает усвоение кучших практик. Проектирование и внеАрение современной инфраструктуры само по себе включает технические знания, опыт, а также управленческие и практические методы Аля тиражирования и внеАрения инноваций, которые развивающиеся страны, в том числе Азербайджан могут использовать.

\section{Основные направления Аеятельности} АзербайАжана и АзБР по обеспечению регионаАьной безопасности

Экономическая политика Азербайджана направлена на достижение устойчивого экономического развития, Аиверсифицированная экономика с Аинамичным не нефтяным сектором, глобальной интеграцией и сбалансированным развитием по всей стране. Тем не менее, нефть и газ остаются важными аля экономики. Углеводороды составмяют около 50\% ВВП и более 93\% экспорта. Но углеводородные места страны подвержены риску нестабильности и вызывают обеспокоенность по ПовоАУ АОАгосрочной Устойчивости роста и стабильности.

АзербайАжан проводит стратегию, которая предполагает краткосрочную максимизацию Аоходы нефти Аля получения необходимых Аоходов аля госуаарственных расходов. Около 58\% бюАжета расходы состоят из трансфертов ГНФАР. Хотя краткосрочные перспективы роста 
АзербайАжана благоприятны, Аолгосрочные перспективы порожАают беспокойство. Эта стратегия нынешнего потребления нефти и полученные среАства явно принесли пользу населению страны в краткосрочной перспективе, с заметным сокращением в бедности, повышении уровня жизни и заработной платы с середины 1990-х годов. Еще это зависимость явмяется промежутком межАу становмением и устойчивым развитием, поэтому АзербайАжан делает большие шаги в сторону не нефтяной экономики.

Нынешние уровни ежегодного увеличения государственных расходов правительства - как номинальные в процентах от ВВП - не явмяются устойчивыми, потому что они полагаются на значительные трансферты из ГНФАР в государственный бюАжет. Учитывая ограничения нефтяного сектора, рост продолжительности жизни и возможность снижения налоговых поступлений в ближайшей и среАнесрочной перспективе, стране потребуется смягчить свои расходы в краткосрочной и среАнесрочной перспективе, чтобы стать более финансово устойчивым. Снижение зависимости бюАжета от доходов от нефти было приоритетом Аля правительства. Переводы ГНФАР в основном используются Аля финансирования крупных проектов, а завершение таких проектов поможет сократить трансферты из ГНФАР. В краткосрочной перспективе ожидается рост ВВП на ... \% в 20.. году, что обусловлено продолжающимся расширением не нефтяного сектора и небольшим увеличением добычи нефти. По оценкам АзБР, в АзербайАжане имеется 7 мимлиардов баррелей (или 1 мимлиард тонн) запасов нефти. Это соотношение запасов к производству составцяет всего 21,9 года, что значительно ниже, чем в среднем в мире. В мире этот показатель составляет 52,9 года. Следовательно, Азербайджан сталкивается с трудной задачей в управлении своими нефтяными ресурсами и доходы Амя буАущих поколений, а расходы на инфраструктуру, необходимые ААя поААержки
Аиверсификация экономики, которая обеспечима бы Аолгосрочное устойчивое экономическое развитие будут расти. Госкомстат и ГНКАР объявили о намерении правительства проАлить проАолжительность добычи нефти и запасов за счет снижения показателей добычи. Более низкие уровни произвоАства в ближайшем будущем может сдерживать экономический рост и негативно повлиять на государственные Аоходы и расходы. Не нефтяной экономический рост по-прежнему зависит от инвестиций государственного сектора, которые зависят от доходов от нефти. Но АзербайАжан к 2020 году пианирует:

1. Переход к экономике, основанной на знаниях и приоритеты развития человеческого капитала;

2. Рост ВВП на Аушу населения более чем в Ава раза - ао \$13000 к 2020 году;

3. Аостичь в среднем рост 7\% ВВП в гоА к 2020 году не нефтяного сектора;

4. Повышение не нефтяного экспорта Ао \$1000 на душу населения к 2020 году;

5. Сократить регионального неравенство с точки зрения качества жизни, производства на Аушу насемения, а также объем инвестиций;

6. Обеспечить постепенное повышение минимальной заработной платы до 60\% уровня от средней заработной платы;

7. Обеспечить более эффективное, надежное и безопасное передвижение мюдей и товаров на внутренних и международных рынках, увеличить Аорожные грузовые перевозки до 14156 млн. тонн/ км к 2020 г, а это на 25\%.больше уровня 2010 г. Пассажирские перевозки автомобильным транспортом увеличить на 20\% в 2020 году по сравнению с 2010 годом и довести до 19960 млн. пассажир/ км, сократить дорожные трафики на 25\% на кажАые 100000 населения к 2020 (то есть до 7,7, хотя Аанный показатель в 2010 году бым 10,3);

8. Обработать и утилизировать в соответствии с межАународными стандартами твердые отХОАЫ АО 1500 тонн в сУтКИ к 2020 гоАУ (хотя 
в 2013 году уровень быи 500 тонн в сутки), сократить выбросы $\mathrm{CO}_{2}\left(\mathrm{tCO}_{2}\right.$ в гоА $)$ на 24000 тонн в ГОА К 2020 ГОАУ.

Пиан оценки рисков и управления рисками АзБР на уровне страны фокусируется на трех темах управмения: управмение государственными финансами, закупки и борьба с коррупцией.

1) Управмение госуАарственными финансами. Рост Аоходов от нефти позволил реализовать амбициозные государственные инвестиционные программы наряду с увекичение заработной платы и социальных трансфертов, что помогло быстро снизить уровень бедности. Ежегодный увеличение бюджетных расходов стало возможным благодаря существенным трансферам Государственного нефтяного фонда Азербайджанской Республики. По сей Аень спрос на финансирование инфраструктуры остается высоким. Государственные инвестиционные расходы распределяется на основе приоритетов, преАставленных отраслевыми министерствами. ОАнако необходимо улучшить установмение приоритетов и планирование проектов минейными агентствами, внедрение инновационных мер Аля адекватной эксплуатации и обслуживание инфраструктуры, Аля обеспечения устойчивости и повышения эффективности аудита.

Аля устранения рисков АзБР предоставим техническую помощь, чтобы помочь разработать формат среАнесрочного инвестиционного плана, связанный с бюАжетом и секторальными результатами, и применять этот формат соответствует ежегодным и среАнесрочным инвестиционным пианам агентств. Техническая помощь Аля госуАарственного управмения поможет государственным органам разработать приоритеты расходов и критерии системы управления. Кроме того, региональная техническая помощь проведет диагностическое исследование практики бухгалтерского учета и аудита, а также укрепить потенциам выполнения и реализации, поАготовки финансовой отчетности проекта и аудиторских заключений. АзБР будет использовать эти инструменты пла- нирования и управления финансами, чтобы помочь государственным органам систематически управцять своими капитальными и операционными расходами. Аополнительное меры снижения риска, такие как улучшение возмещения затрат, вовцечение частного сектора в инфраструктуру, а также обязательные внешние аудиты по кредитным соглашениям.

2) Закупки. Количество и стоимость государственных контрактов аля государственных закупок увеличиваются ежегодно. Выявленные риски, связанные с закупками в Азербайджане, включаЮт слеАующее:

- слабые возможности закупок приводят к заАержкам, неэффективности и неоптимальному заключению контрактов;

- неадекватные рамки национальных закупок ограничивают конкуренцию;

- непрозрачные и преференциальные условия закупок ограничивает конкуренцию;

- отсутствие проверки оригинала предложений и проведение выборочных проверок информации, преАставленной в преАложениях;

- слабые проверки конфликта интересов в процессах закупок и формамьный запрос корпоративных сертификатов собственности с указанием финансового бенефициара Амя подрядчиков и поставщиков.

ПреАложения АзБР по закупкам и процессов закупок предусматривают снижение этих рисков и буАут применяться в буАущем ПосреАством программирования. АзБР преАлагает подАерживать пороговые уровни текущих закупок, преАварительное рассмотрение методов закупок и преАможений государственных органов.

АзБР преАоставит техническую помощь Аһя подАержки правительства в:

- проведении реформы закупок, опредемение объема работ и планирование действий;

- разработке обновленного законодательства о закупках, выполнение правии и соответствующих Аокументов; 
3) Анти коррупция. АзербайАжан продемонстрировац значительный прогресс в борьбе с коррупцией с середины 2015-х годов. АзербайАжан участвует в нескольких глобальных и региональных антикоррупционных инициативах, также правительство осуществило Национальный план Аействий по борьбе с коррупцией, 2012-2015 годы. В дополнение к профилактическим мерам, которые Аолжны быть предприняты через связанные с закупками деятельностью, АзБР продолжит совершенствовать навыки исполнительных органов. АзБР разрабатывает и предлагает инструменты, которые помогают выявмять мошеннические преАложения и практики, а также сговорные ситуации. АзБР также проводить обучение сотруАников исполнительных органов и Аругих правительственных партнеров, а также Аеловое сообщество и гражАанское общество. В ходе реализации проекта АзБР выявлено потенциальное неправильное использование ресурсов или персонала, проведена замена Аля обеспечения соответствия техническим и каАровым ожиАаниям. АзБР проводит тщательный ситуационный анализ, детальные оценки и регулярный мониторинг выполнения проекта. Соответствующие положения Антикоррупционной политики АзБР вкАючены в кредитные и проектные соглашения и тендерные документы.

Увемичение государственных инвестиций, повышение заработной платы, большие отчисления на социальные расходы, скорее всего, станут движущей силой инфмяции. С возобновлением роста в экономике и не нефтяной экономики, вероятно, ожидается рост инфмяции. Темпы роста в среАнесрочной перспективе будут более скромными по сравнению с высокими темпами связано с сереАины 2000-2017-х гоАов. САвиг Арайверов роста продолжится в сторону от нефтяного сектора в сторону не нефтяной экономики. Тенденция к замеАлению роста экономики Аолжна помочь ограничить инфмяцию, но риск инфмяционного Аавления все еще будет существовать из-за увеми- чения Аоходов от нефти, внутреннего спроса на высокие государственные расходы и расширение внутреннего креАита.

Необходимо увеличить инвестиции в частный сектор, но это, вероятно, требует преодоления препятствия в деловой среАе, которые сАерживают частный сектор. СреАи основных ограничений выдемяют:

- ограниченный доступ к финансам и неразвитая финансовая система;

- монополии, которые доминируют в большинстве секторов бизнеса и препятствуют конкуренции;

- высокий уровень бюрократизации;

- недоразвитая инфраструктура;

- нехватка квалифицированной рабочей силы.

Среди азиатских странах Азербайджан занимает низкое положение по нескольким показатеАям, это:

- непогашенные кредиты коммерческих банков (в процентах от ВВП);

- низкие депозиты вкладчиков коммерческих банков (на 1000 человек).

\section{ВЫводы}

Учитывая выше сказанное необходимо сформировать возможные направления сотрудничества Азербайджана с АзБР на более Алительную перспективу.

1. Рост внешнеполитических интересов основных держав к АР, актуальность вопросов безопасности, реконструкция энергетических, транзитно-торговых и продовольственных каналов и многие Аругие аспекты повышают значимость АР в регионе и Аля АзБР. Но интересы стран периодически меняются, расширяются или сужаются торгово-экономические отношения. Ясно и то, что этому виной является мировой экономический кризис, политические трения, военные Аействия и многие Аругие факторы, которых возможно предугадать. Устойчивые, всеобъемлющие инвестиции в инфраструктуру явмяются Амя АзБР приоритетными. АзБР будет тесно сотруАничать 
с развивающимися странами Аля производства актуальных информационных продуктов и услуг. АзБР проводить активные разработки, Аает рекоменАации по увемичению качества

2. Проводимой политики, укреплению институционамьного потенциама страны и как расширить сотруаничество в области образования. АзБР расширяет также Аействия в социамьной сфере. АзБР, Аиверсифицируя операции в преАпринимательском секторе, хочет к 2024 году Аостичь уровня этих операций Аля частного сектора более чем на $30 \%$.

Если проанализировать деятельность АзБР в странах СНГ, то мы обнаружим, что объектами интереса АзБР явмяются, такие отрасли как с/хво, энергетическая промышиенность, финансовый, транспортный сектор, ИКТ и социамьные инфраструктура. Стыковка интересов явмяется только началом сотруАничества, а Алитемьность сотрудничества требует более тщательного исслеАования. Развитие энергетического, транспортного, аграрного секторов и их инфраструктуры, повышение уровня жизни населения страны, устранение беАности и многие Аругие цеми явмяются обоюАно приоритетными Амя АзербайАжана и АзБР. Результат сАеланных анализов выявило нижеслеАующее сходство межАу целевыми компонентами АзБР и национамьными интересами АР:

- Обеспечение устойчивого роста экономики АзербайАжана Амя обеих сторон явмяется актуацьным и основным стратегическим Аостижением региона;
- Соблюдение инАикаторов экологической устойчивости необходимо Амя повышения конкурентоспособности и устойчивого развития как AР, так и всего региона;

- Модернизация структуры административного управления и экономики сэкономить государственные расходы и будет способствовать устранению неэффективного использования средств, что обеспечить инновационно-рационамьной структуры и сокращение финансовой зависимости в перспективе;

- Развитие частного сектора, улучшение бизнес-процессов и повышение производительности труда Ааст возможность обеспечить национамьную, экономическую безопасность АзербайАжану, умучшить торгово-экономические связи со странами региона;

- Снижение уровня бедности, обеспечение Аостойного уровня жизни буАет способствовать миквиАации социамьных кризисов, повышению качества человеческих ресурсов;

- Инклюзивный рост, обеспечивающий полное использование трудового потенциама и максимизации занятости, устранению гендерной Аискриминации Ааст возможность перейти на высокую ступень развития как стране, так и региону;

- Региональная интеграция будет способствовать росту партнерства и всестороннему сотрудничеству стран региона, обеспечению внешнеэкономической безопасности не томько Амя АзербайАжана, но и Амя всего региона.

\section{Список митературы:}

1. Андропова И. В., Кучерявый П. В. Азиатский банк развития: инвестиции в развитие. Вестник межАународных организаций. 2011.- № 4.- С. 61-67.

2. Емельянов Ю. С. Банки развития и государство в современной архитектуре мирового развития. Экономика и политика. 2009.- № . 5.- С. 11-18.

3. Исаев Ю. Ю. Банки развития как важнейший инструмент реализации государственной инвестиционной политики // Вестник финансового университета. 2006.- № 4.- С. 61-72.

4. Ковалев М. Роль банков развития в XXI веке / - М. Ковалев, Ю. Когут, С. Румас. Вестник ассоциации беморусских банков. 2014.- № 2.- С. 2-17. 
5. Кучерявый П. В. Региональные (субрегиональные) банки развития в мировой экономике: критерии оценки их инвестиционной привлекательности. Автореферат канА. Аисс.- М.: ВШЭ, 2012.- 18 с.

6. Никонова И.А. Банки развития: оценка эффективности кредитно-инвестиционной деятельности // Труаы ИСА РАН. 2013.- Т. 63.1.- С. 77-84.

7. Обзоры инвестиционной деятельности международных банков развития. URL:https://eabr.org/ analytics/industry-research/reviews-idb-investment

8. Чувахин П.И. Правовые вопросы деятельности Азиатского банка развития как межправительственной региональной финансовой организации / / Образование. Наука. Научные каАры. 2015.№ 3.- С. 66-69.

9. ADBannualreport2015.URL:http://www.adb.org/sites/default/files/institutional-document/182852/ adb-annual-report-2015.pdf

10. ADB charter: agreement establishing the Asian Development Bank. URL:https://www.adb. org/sites/ default/files/institutional-document/32120/charter.pdf

11. Asian Development Bank (ADB), Data and Research, 2018. URL:https://www.adb.org/

12. An Overriev of Development Bank and Guarantee Agency Services for Infrastructure Finance // OECD. 2010.- 10 p.

13. Bruck N. The Role of Development Banks in the $21^{\text {st }}$ century // ADFIAP [Electronic research]. 2012.Mode of access: URL:http://www.adfi ap.org/wp-content/uploads/2009/10/therole- of-developmentbanks-in-the-twenty-fi rst-century.pdf.-Date of access: 09.01.2015.

14. From Billions to Trillions: Transforming Development Finance. Post-2015 Financing for Development Multilateral Development Finance.2015. WB - IMF.- 27 p.

15. Griffi th S. Enhancing the Role of Regional Development Banks / S. Griffi th, D. Griffi th, D. Herlova Geneva: UN. 2008.- 24 p.

16. Gutierres E. Development Bank: Role and Mechanisms to Increace their Effi ciency. E. Gutierrez, H. Rudolph, T. Homa, E. Beneit.- World Bank. 2011.- 35 p.

17. Luna-Martinez J., Vicente C.L. Global Survey of Development Banks // The World Bank, Police Research Group [Electronic research]. 2012.-36 p.- Mode of access: URL:http://www-wds.worldbank. org/servlet/WDSContentServer/WDSP/IB/2012/02/15/000158349_20120215153214/Rendered/ PDF/WPS5969.pdf.- Date of access: 21.01.2014.

18. Nelson R. Multilateral Development Banks: Overview and Issues for Congress.Congressional Research Service. 2013.- 20 p.

19. Rethinking the Role of National Development Banks / / UN, Department of Economic and Social Affairs 2005.- 43 p.

20. Role of Multilateral Development Banks in Emerding Market Economies. Carnegie Endowment. 2001.$57 \mathrm{p}$.

21. Ferroni M. Regional Public Goods and Regional Development Banks.- New York. IADB. 2004.- 19 p.

22. URL:http://182.50.129.37/uploads/docs/CAREC-Publications/2012/CAREC-2020-StrategicFramework-ru.pdf

23. URL:https://www.adb.org/sites/default/files/institutional-document/388801/carec-2030-ru.pdf 
Borisik Olga Viktorovna, PhD, associate professor of World economy department Belarusian State Economic University, Minsk, Belarus E-mail:olga_star79@mail.ru

\title{
MULTI-FACETED DEVELOPMENT OF EURASIAN ECONOMIC INTEGRATION IN THE CONTEXT OF THE ECONOMY OF TRUST
}

\begin{abstract}
The article reveals the theoretical aspects of the economy of trust as an economic category. Special attention is paid to the factors influencing the formation and development of the economy of trust in Eurasian Economic Integration. On the basis of the analysis performed, there have been identified the results of formation of the economy of trust in the Eurasian Economic Integration and also there have been proposed the measures for their improvement.
\end{abstract}

Keywords: economy of trust, integration of trust, inclusive growth, digitalization of the economy, Eurasian Economic Union.

There are various definitions of the "trust" term (Lorenz E.H. (1988), for example, defines trust as follows: "I would like to suggest that the transaction cost literature...can tell us something about the role of trust in the economy... Trust enters into the argument because the presence of these [transaction] costs is directly linked to the possibility that economic actors will behave opportunistically... If transactions are thought of as friction in the economy, then trust can be seen as an extremely effective lubricant" $[2,195]$. At the same time, the lack of a clear definition of the "economy of trust" term causes certain analytical difficulties. The economy of trust is defined as the area of economic relations that organically combines private and public interests; its core is the market for social goods (the so-called social capital), which is being formed at the border of the market for private goods and the public goods production field that provides favorable conditions for the realization of the creative potential of a person, team, and society $[1,68]$. In the author's opinion, the economy of trust is an economic activity based on the development of social capital carried out by economic actors under conditions ensuring the trust at all levels which results in a rational distribution of all available resources, inclusive growth and achievement of economic, political, social and other significant goals.

In this case, the economy of trust in the processes of economic integration (integration of trust) may be viewed as the creation of conditions for the development of integration potential, ensuring the trust of subjects of international integration at all levels, with an eye toward achieving the goals to be sought.

The economy of trust shall be distinguished from the sharing economy. The sharing economy is an interaction between two parties, one of which has resources and does not use them, and the other one is willing to rent these resources for a while to meet their needs. As a result of this exchange, transaction costs are reduced and the problem of inefficient use of resources is solved.

The main characteristics of the economy of trust are as follows:

- the union of private and public interests;

- ensuring the confidence of economic actors at all levels (interpersonal, institutional).

Creating conditions that ensure the trust of economic entities at all levels is manifested in:

- facilitation of the coordination of interests of participants in economic interactions; 
- reduction of investment risks (the uncertainty of actions and the threat of opportunism is reduced);

- reduction of transaction costs (costs of monitoring, control, protection of property rights, etc.);

- high quality of social capital as a condition for the functioning of the economy of trust;

- sustainable inclusive economic development in order to improve the welfare of society.

Trust is the basis for the sustainable development of the Eurasian Economic Integration participants. What is more, it is the basis for the sustainable development of both the member countries separately, and the integration association as a whole. Building trust is necessary at all levels of economic integration: between people (interpersonal trust), between society, business and government, integration institutions (institutional trust), between economies. Integration of trust shall be based on the principles of openness of economies, transparency of state regulation, fair social policy, which correspond to the main goals of the Eurasian Economic Integration, i.e. the growth in population wellbeing and improving the competitiveness of the country. The digitalization of all forms of business, government administration and social interaction shall be the most important tools for building such economy.

The conditions for the economy of trust in Eurasian Economic Integration are as follows:

- the functioning of domestic markets without barriers, derogations and restrictions. Economic and legal derogations in the EAEU are the main deterrent elements that impede deeper integration and give rise to complex custom outcomes, violate the mechanism for the implementation of fair competition between the subjects of the Eurasian Economic Union, including equal access to the common market. In addition, recently the number of derogations has increased significantly due to the fact that the invasion processes of supranational principles into the system of interstate interaction of national markets under conditions of an aggressive external environment and the emergence of new extreme factors are becoming much more complex today than it was a few years ago $[3,37-38]$. Countries spend enormous resources (time, finances) on investigations, overcoming the barriers, derogations, restrictions that undermine not only trust within the integration, but also the image of the EAEU on the global stage.

- strengthening of the international cooperation. Trust is the basis of international cooperation and lasting peace. The economy of trust is impossible without the strengthening of international cooperation on the terms of mutually beneficial openness of economies, and countering unilateral protectionism. Building closer cooperation with the CIS countries, the SCO, expanding the network of free trade agreements with third countries and integration associations, strengthening the cooperation with international organizations (WTO, UNECE, UNCTAD and other organizations) will allow the union to enhance its economic position in the Eurasian space and become the center of the interregional project the "Comprehensive Continental Partnership".

- forming-up a coherent industrial policy. The guidelines of industrial cooperation within the EAEU include industrial cooperation, collective import substitution, aligning in value-added interstate chains. Moreover, the return on industrial capital increases in a favorable social environment which in addition to production development includes trust and confidence in the mutual benefits of social partnership. The results of the import substitution in the EAEU have shown that the share of imports in the Eurasian industrial market in 2017 decreased compared to 2013 by 2.8 percentage points from $25.6 \%$ to $22.8 \%$. The largest decline in the share of imports was achieved in the wood processing industry (by $3 \mathrm{pp}$ ), chemical production (3.4 pp) and metallurgy (5.9 pp), as well as in the production of vehicles and equipment (5 pp) [4]. These results indicate that the employment of moderate protectionism on the territory of the Eurasian space at current stage of its 
economic development is more than justified. Collective import substitution in the Eurasian Economic Union, firstly, contributes to the endogenous modernization of its member countries, and, secondly, to some extent contributes to overcoming "unilateralism" in terms of raw materials in the economy of the Russian Federation and the Republic of Kazakhstan, and also contributes to preserving the accumulated production potential in manufacturing industry of the Republic of Belarus and the development of the industrial sector and agriculture in the Republic of Armenia and the Kyrgyz Republic. This is due to the growth of domestic demand for goods and services of national manufacturing and other industries. At the same time, it is important to choose exportoriented innovative import substitution, which will facilitate entry into stable and solvent markets and be a necessary step for further qualitative growth of the national producers.

The alignment of national producers into the technological chains of partners in the EAEU and foreign manufacturers in developed countries has a great potential in manufacturing sector. Within the context of mutual trade, it concerns the supply of both intermediate goods for further assembly and final products. The alignment of national enterprises (including import-substituting) in the production chains of international companies is beneficial for several reasons: attracting investment and advanced technologies, no costs for brand promotion, promotion in the technological chain from the supply of relatively simple products and components to wider participation in the final product, job creation, tax revenue to the budget. The union has already implemented the first integration projects (the HORSCH (Germany) plant for the production of sowing and soil-cultivating equipment has been established in the town of Chaplygin (Lipetsk region). An interstate program list of activities for the development of the Earth's remote sensing system (ERS) has been prepared based on national operators of Belarus, Kazakhstan and Russia, which will include the ground- based satellite control facilities engaged in Earth sensing.

- ensuring the inclusive growth. The issue of ensuring the inclusive growth of the EAEU member states is quite relevant in connection with the declared purpose of the Union - creation of conditions for the sustainable development of the economies of the member states in order to advance the living standards of population. In the interpretation of the ECE, inclusive growth is defined as the convergence of the quality of life of all groups of a country's population, achieved not only by the state's redistribution of economic results, but also to a large extent by creation of favorable non-discriminatory conditions in the economy that allow each group of the population to independently provide itself with the quality of life comparable with the one of other groups while advancing the country's quality of life in whole [4]. Trust is the basis of these non-discriminatory favorable conditions, which include: advancement of the quality of life, creation of favorable conditions for living, renewal of education and the increase in funding of science, greater investments in human capital, educational and health care reforms, pave the way for creative self-expression.

The assessment of growth inclusiveness in the EAEU countries has shown that in three countries the Republic of Belarus, the Republic of Kazakhstan and the Russian Federation - there is a sufficiently high degree of inclusive growth. At the same time, according to some indicators, the EAEU member states do not correspond to the level of the overwhelming majority of OECD countries (including: difficulties in ensuring access of the entire population to high-quality logistics infrastructure, low values of important indicators of the Healthcare and Longevity Group) [5].

- the formation and development of the digital transformation of the economy (digitalization of the economy), covering all spheres of economic and social activity are the most important conditions for inclusive sustainable economic development of the 
integration association. Digitalization is a tool of the economy of trust. Within the context of digitalization, electronic public services are being intensively developed in the Eurasian integration, which inevitably raises questions of trust in identifying and authenticating participants of electronic interaction, trust in electronic signatures, time, and authorities. In this regard, it has been decided to create a cross-border space of trust of the EAEU member states (A cross-border space of trust is a combination of legal, organizational and technical conditions agreed by member states to ensure confidence in the interstate exchange of data and electronic documents between authorized bodies) [7]. The development of the cross-border trust space opens up new horizons for improving business climate in the countries of the Union, makes it possible to more fully utilize the economy of scale and create a unified environment of trust.
Thus, it can be argued that the further development of Eurasian integration and effective use of the integration potential is possible only in terms of trust at all levels (interpersonal and institutional; trust between people (labor migration, refugees, etc.), public and business trust in the state (trust in integration institutions).

The important conditions for the economy of trust in Eurasian Economic Integration are as follows: the functioning of domestic markets without barriers, derogations and restrictions; strengthening of the international cooperation with third countries, integration associations, international organizations; development of a coherent industrial policy in such areas as industrial cooperation, collective import substitution, aligning in value-added interstate chains; ensuring the inclusive growth of the EAEU member countries and the digitalization of economies.

\section{References:}

1. Артемова Т.И. Экономика доверия как прообраз институциональной архитектоники / Т.И. Артемова / / Экономическая теория. 2010.-Т. 7.- № 3. 2010.- С. 60-68.

2. Lorenz E. H. 'Neither friends nor strangers: informal networks of subcontracting in French industry' in D. Gambetta (ed), Trust: Making and Breaking Cooperative Relations, Oxford: Basil Blackwell: 1988.P. 194-210.

3. Ковалев В. Е. Экономико-правовые изъятия и их влияние на развитие национальных рынков Евразийского экономического союза / В.Е. Ковалев / Э Экономический рост Республики Беларусь: глобализация, инновационность, устойчивость: материалы XII межАунар. науч.-практ. конф., - Минск, 16 мая 2019 г. / Беморус. гос. экон. ун-т; реАкол.: В. Н. Шимов [и Ар.].- Минск, 2019.- С. 37-38.

4. Евразийская экономическая комиссия: официальный сайт [Эмектронный ресурс]. 2019.- Режим Аоступа: URL:http://www.eurasiancommission.org.- Аата Аоступа: 25.04.2019.

5. Инклюзивный рост государств - членов Евразийского экономического союза / АоклаА Евразийской экономической комиссии (ЕЭК) и ЮНКТАА: [Электронный ресурс]. 2019.- Режим доступа: URL:http://www.eurasiancommission.org/ru/nae/news/Pages/26-06-2019-4.aspx.- Аата Аоступа: 25.04.2019. 


\title{
Section 4. Innovation management
}

\author{
Kuznetsova Valentina Petrovna, \\ $P h D$, professor, the Faculty of Economics and Management \\ Vardamatskaya Ludmila Petrovna, \\ Tropinova Elena Aleksandrovna, \\ Radchenko Yulia Yurjevna, \\ Herzen State Pedagogical University \\ E-mail:vpr1000@yandex.ru
}

\section{POSSIBLE SOLUTIONS OF IMPLEMENTING BLOCKCHAIN TECHNOLOGIES IN RUSSIA}

\begin{abstract}
The article defines specific directions of blockchain use in education, pharmaceuticals, and healthcare. The strategies to reduce labor and energy costs for information processing, accelerate the creation of new treatment technologies and the creation of drugs, their implementation in practical health care are proposed. The result of the introduction of blockchain technologies will be the automation of production processes and the provision of services, which will lead to the era of digital contracts and paperless transactions, to increase the speed of processing the material, ensuring transparency and impossibility of loss, damage or forgery of the document, significant resource savings.

Keywords: blockchain, digital economy, pharmaceuticals, healthcare, education, monitoring of drug turnover, unified register of electronic prescriptions.

Digital technologies are becoming a priority for the development of the national economy of our country, which owns the future. The transition to blockchain, as the technology of the digital economy, is already becoming a necessity [13].

A blockchain is a chain of blocks, a distributed database that anyone can access. In other words, it is a "distributed registry technology"; there is no centralized regulator that could control the blockchain at its own discretion [10]. Don Tappsott and Alex Tappsott in their work "Blockchain Revolution: How the Technology Behind Bitcoin Is Changing Money" complete this definition with the blockchain economic principles: network integrity, load distribu-

tion, value as incentive, security, privacy, security of rights, involvement [1].

The unique feature of the blockchain is that the data entered once has its own history, which allows you to check the origin of information and its authenticity. These data can not be changed by anyone, they are duplicated many times and stored in a distributed network created and maintained by all participants. Information in the database can not be overwritten. The authenticity of the document is easily traced, since each participant sees by whom he was recorded in the blockchain system. Information is always available, transparent. Databases make it extremely resistant to hacker attacks, it has
\end{abstract}


a low maintenance cost. In addition, thanks to such technology, it is possible to avoid numerous errors in transaction processing and reduce the number of fraudulent transactions [7].

Blockchain is gradually being introduced not only in all areas of business, but also in the social sphere: education, pharmaceuticals, healthcare [11].

Blockchain in education. The problem of educational institutions is that they are strongly attached to physical media. This, in its turn, leads to the situation when the collection of information with the use of physical media creates an additional burden on employees; forms of reporting on performance in different educational institutions may not coincide, which reduces the efficiency of staff; the lack of a complete database of graduates with specific skills makes it difficult for employers to find the right specialists; the lack of an open database on the employment of graduates and their transfer to another job does not allow educational organizations to assess the effectiveness of their work in their programs and make quick adjustments; lack of openness and transparency of the financial flows of the educational institution, distribution of finances among various structural units, participation in the tender and other problems. In order to solve all these problems and increase the efficiency of the work of educational organizations, it is necessary to introduce modern technologies and in particular blockchain technologies in the field of education. Their advantages are: rejection of physical media in favor of digital, which will reduce the number of references and other forms of reporting; cutting down the number of intermediate parties; creating products individually for each consumer. Services and educational products in the digital world can be quickly brought to the world market and can be used by anyone. Such educational product can quickly respond to customer needs; furthermore, the cost of online services is usually lower [9].

The blockchain technology in educational institutions is already widely used in foreign countries and opens up huge opportunities for its effective use.
For example, in Japan, Singapore, USA, Hong Kong, Estonia, Great Britain [15], Australia [3], blockchain technologies are already being actively introduced, and the Singaporean educational system makes extensive use of online learning and is considered one of the best [2]. In Russia, the St. Petersburg National Research University of Information Technologies, Mechanics and Optics has already begun to actively explore this technology and is planning to implement the blockchain [12].

Blockchain in pharmaceutical industry. It is impossible to ensure full control over the quality, safety and efficacy of drugs with existing technologies for their production and sale. This is evidenced by the high percentage of circulation of counterfeit medicines in both the domestic and global markets. Often these drugs are accompanied by false information about the composition or manufacturer of the drug. Thus, WHO presented a report on the market for counterfeit drugs, which could kill hundreds of thousands of people. WHO experts estimated the global volume of this illegal market at $\$ 30$ billion [8].

In this regard, there is an urgent need to track information at all stages of the development and supply of products created using the latest technologies in the field of electronics, which will make it impossible to sell counterfeit medicines [8].

For now there are successfully developed projects in the field of use of the blockchain in the fight against counterfeit in the pharmaceutical industry abroad [5].

One of the directions for the introduction of the blockchain in Russia is associated with the labeling of drugs with a special chip for protection against fakes, i.e. blockchain technology will be used at all stages of the movement of the drug from the manufacturer to the patient. So, as an experiment, Bank for Development and Foreign Economic Affairs organized the implementation of a drug monitoring program based on the blockchain technology in a hospital in the Novgorod region in April of 2018 [6]. 
Thus, the introduction of blockchain technology in pharmaceuticals industry will allow:

- to transfer the entire document flow of pharmaceutical organizations to the Blockchain [4];

- to ensure the impossibility of falsifying information and prevent the implementation of poor quality or counterfeit medicines to patients;

- to create a unified register of electronic prescriptions to combat counterfeit drugs and resale of expensive drugs purchased at the expense of budget funds;

- to transfer prescription drug records from physical media to electronic ones;

- to create a register of medical information about patients across the country by disease group;

- to ensure transparency of financial flows of healthcare institutions and reduce the number of subjects of financial relations;

- to assign the bulk of the cost of quality control of medicines to the manufacturer, as he is interested in promoting his products and preventing counterfeit products from entering the market. In this case, budget costs associated with quality control will be reduced.

Blockchain in healthcare. In our country, most medical documents are issued on paper; there is no single register of information about patients, which would include all information about their visits to medical organizations, and not only public but also private ones. The patient's medical history is also made out mostly by hand, and this information can easily be made public, which negatively affects the need to preserve medical confidentiality. In the case of a medical error, including fatal, data on the patient's health status, as well as treatment technology can be easily changed or adjusted. In this regard, it is expected in the near future to create an information system that will work on the blockchain principle [14].
Thus, the introduction of blockchain technologies in healthcare will allow:

- to simplify the assessment of the quality of medical care, which will positively affect the efficiency of the work of medical personnel;

- to transfer all health care documents to the blockchain, which will increase the processing speed of the material, ensure transparency and the impossibility of losing, damaging or falsifying documents, since the block created once cannot be changed, it cannot be removed from the network;

- to ensure transparency of financial flows of healthcare institutions and reduce the number of subjects of financial relations;

- to keep the copy of the entire database for each patient using a single protocol;

- for the potential employer to gain access to the professional data of the health worker and to confirm the competence he has;

- to reduce the burden on the physician in keeping the history of the disease for each patient;

- to move to the era of digital contracts and paperless transactions, which will significantly reduce the cost of maintenance;

- to create a register of medical information about patients across the country sorted according to incidence groups that will result in:

1. Facilitation and acceleration of health research;

2. Identification of more effective and high-quality treatment methods and its further implementation in practical health care;

3. Acceleration of the development of new drugs and decrease of the cost of this process.

Ultimately, the introduction of blockchain technology and the expansion of its application in the social sphere is one of the priority areas for the development of the digital economy that will help to achieve the increase in the medical, social and economic efficiency of the economy. 


\section{References:}

1. Tapscott D., Tapscott A. Blockchain Revolution: How the Technology Behind Bitcoin Is Changing Mopey, Business, and the World. - New York: Portfolio. 2016.- 368 p.

2. Webber N. University of Melbourne to issue recipient-owned blockchain records.Department: Media 9 October, 2017. Retrieved from: URL:http://newsroom.melbourne.edu/news/university-melbourne-issue-recipient-owned-blockchain-records?_ga=2.100100759.802664920.15076514671328473086.1507651452

3. University of Melbourne to issue recipient-owned blockchain records. Retrieved from: URL: https://about.unimelb.edu.au/newsroom/news/2017/october/university-of-melbourne-to-issue-recipient-owned-blockchain-records

4. Plotnikov V., Kuznetsova V. The Prospects for the Use of Digital Technology "Blockchain" in the Pharmaceutical Market. International Scientific Conference Environmental Science for Construction Industry-ESCI 2018.- Vol. 193. 2018.

5. Alexander A. Blockchain will help in the fight against counterfeiting. Retrieved from: URL:https://dailyhype.ru/2018/02/19/blokcheyn-pomogaet-v-borbe-s-kontrafaktom-v-farmacevtike.html

6. Levkovich A. VEB launched a system of monitoring circulation of drugs on the basis of the blockchain. Retrieved from: URL:https://vademec.ru/news/2018/04/16/veb-zapustil-monitoring-oborota-lekarstv-na-osnove-sistemy-blokcheyna-v-novgorodskoy-oblasti

7. Blockchain without intermediaries. Sekret firmi [e-magazine] 2017. Retrieved from: URL:https://secretmag.ru/trends/scenarios/blokchein-mir-bez-posrednikov.htm

8. Khovstik E. The world market for counterfeit drugs was estimated at $\$ 30$ billion By the who report on the market for counterfeit drugs. Retrieved from: URL:https://www.kommersant.ru/doc/3481234. 28 Nov, 2017.

9. Zolotikh O. The Digitalization of the economy // Business \& information technology.- Issue № 08(71). 2017.

10. Kuznetsova V.P., Bondarenko I. A. Blockchain in education // Russia: tendencies and perspectives of development. Institute of Scientific Information for Social Sciences of the Russian Academy of Sciences, 2018. - P. 858-860.

11. Kuznetsova V.P., Bondarenko A.I., Journal of Economic Regulation. 2018.- Vol. 9.- No. 1.- P. $102-109$.

12. Mikhailova E. Culture in the "figure": why the professional of the future should be a little "IT specialist". Retrieved from: URL:http://news.ifmo.ru/ru/education/trend/news/7234

13. Order of the government of the Russian Federation of July 28, 2017. No. 1632-R. "On approval of the program "Digital economy of the Russian Federation". The program "Digital economy of the Russian Federation”. Retrieved from: URL:http://static.government.ru/media/files/9gFM4FHj4PsB79I5v7y LVuPgu4bvR7M0.pdf

14. Federal law N242 of 29 July, 2017. "On amendments to certain legislative acts of the Russian Federation on the use of information technologies in the field of health protection”. Rossiyskaya Gazeta - Federal issue No. 7338. August, 2017.

15. Sherstobitov S. Digitalization of the economy / / Business \& information technology.- Issue No. 08 (71). 2017. 


\title{
Section 5. Labour economics
}

\author{
Karimova Minura Haji, \\ Azerbaijan Technological University \\ E-mail:f.kerimov@uteca.edu.az
}

\section{SOME ECONOMIC ASPECTS OF THE IMPROVEMENT OF THE USE OF MATERIAL-TECHNICAL PRODUCTION RESOURCES IN AGRICULTURE}

\begin{abstract}
The market of material and technical resources is a necessary market infrastructure that ensures substantial quality changes in the sustainable development of production through technical means. The market of material and technical resources is an institution that stimulates the development of production as other types of market. Reforming in all areas of the economy has become an objective necessity for the development of entrepreneurial activity in the supply of material and technical resources, as well as new sales spheres.
\end{abstract}

Keywords: Market infrastructure, logistics market development, entrepreneurship development, re-production, supply with logistics, capital investment, new modern technology, unusual climate conditions of scientific and technical progress, etc.

The market of material and technical resources is an economic entity that operates on the basis of commodity-money relations and free competition in order to obtain production and circulation funds between enterprises and organizations operating in all sectors of the economy irrespective of their ownership. Since the market of logistics resources is an important part of the free market operate on demand and offer. In the said market, economic relations are based on the agreements and contractual relations between the parties. The market of material and technical resources is crucial for the implementation of extensive reparation in all sectors of the economy and the sustainability of development.

In the market, the buyer must have a certain amount of capital to acquire the technical resources he needs, and the vendor must offer the resources necessary for economic entities. The economic relations in the market of material and technical resources are formed on the basis of demand

and supply, can be considered as an analogue. The market of material and technical resources is more important than the agrarian sector development. Providing resources to the agrarian sector creates favorable conditions for the growth of production of agricultural products. Under the conditions of socialist production relations, technical support of agricultural enterprises was carried out by the state in a centralized manner. As well as myths, centrifugal trends in the economy since the early 1990s have led to destructive trends in supplying the agrarian with material and technical resources. All of this has led to the limitation of the production capacity of newly created agricultural commodity producers. The market of material and technical resources can not function without forming a flexible economic mechanism.

As it is well known, the economic mechanism, which plays a key role in the development of agrarian sphere in market conditions, is closely linked to the 
specific characteristics of agricultural production, unlike other branches of the national economy.

These qualities are primarily due to the dependence of agricultural production on soil climatic conditions. On the other hand, the development of the agrarian sector is also linked to biological factors. In general, the agrarian sector is characterized by a rather complex and risky system of economy, unlike other sectors of the economy, given the properties deriving from property and production relations in general. Material resources in agriculture consist of fixed assets and material resources, together with soil and water resources, constitute an important element of productive forces such as agriculture production.

The solution of complex issues on the basis of the principles of natural, technological, financial, credit, price, tax, customs, insurance, stimulation of production, mutual economic relations on the principles of market relations, etc. other important issues. From this point of view, it is one of the main conditions for the complex and purposeful use of the economic factors mentioned above to develop the agrarian sector in accordance with market principles and to ensure the efficient functioning of this field. Thus, it is impossible to achieve any results if the specific characteristics of the agrarian field are not taken into account in the complex use of agro-technical, organizational-technological, economic material and technical resources.

On the other hand, financial difficulties arising from the material and technical capacities of the enterprises, the high level of competitiveness of the enterprises, the qualitative approximation of production resources and the protection of commodity producers from the unfavorable effects of the external market condition the state's constant support for the agrarian sector. Thus, the application of certain privileges by agricultural commodity producers in the state, tax, financial-credit, banking, investment and pricing policy, application of dotation, provision of agrarian material with material and technical means, both in foreign and domestic trade, the need for sus- tainable government regulation should be pursued, since there is a great need for assistance.

The cultivation of agricultural crops and their high productivity depend on the fertility of the land, the level of irrigation, the provision of agricultural commodity producers with elite seeds, and compliance with agro-technical regulations.

On the other hand, cultivation of any plant and the achievement of targeted productivity requires special mild weather and fertile soil conditions. So, cotton plant is a very important condition for longterm heating, irrigation water, fertile soils, tea plantation, mild and damp weather throughout the year, and a specially trained land. Such properties also apply to other plant species. It should be noted that the land areas existing in the country are substantially different from their natural fertility, which requires different levels of production at the same level. To do this, increase the soil fertility and provide the same level of productivity and soil requiring different levels of circulation. Naturally, all these are directly dependent on the efficient use of production and circulation (buildings and structures, machinery and equipment, productive livestock, seeds, seeds, feeds, etc.). The development of some areas in agriculture is also of local character. However, the placement of most plants and the entire range of animal species on the territory is a broad range. The effective development of the region by the regions has a positive impact. Therefore, one of the key issues for the development of separate agricultural products production is the importance of the efficient functioning of the market economy, with proportionate placement of agricultural raw materials and processing industries.

One of the most important factors in solving this problem is the creation of optimum inter-field structures of the agrarian sector.

On the other hand, the lack of clear proportions between agricultural raw material processing and food industry enterprises has a negative impact on the efficient use of production. This also weakens the sales activities and results in raw material losses. 
Unlike other areas, a livelier labor force is needed to develop agricultural production. Otherwise, the agricultural production season is characterized by the fact that the use of force decreases below $50 \%$ of existing labor reserves.

Agricultural production is seasonal and expires in the middle of the year, negatively affecting the use of production resources at an equal level throughout the year. Therefore, in addition to the main areas of agriculture, the development of subsidiary areas is a key condition.

Agriculture is simultaneously a household. In addition to agricultural production, various economic functions, such as households, household services, family consumption, the social needs of the elderly and unmarried family members, the conduct of households, the upbringing of the younger generation, vaccination, solution of professional issues, organization of labor resources for the sphere of national economy, etc. realize.

Agriculture is always at risk. Above all, unexpected weather conditions, possible natural disasters, frequent changes in production and organization of production and replacement of prices create conditions for environmental pollution through the use of mineral fertilizers, toxic substances and herbicides. There is no stable and secured market for agriculture, and it often changes.

Agricultural commodity producers have the exclusive right to access material and technical means of repair, construction, transportation and other types of services, the determination of prices for products, and the identification of buyers.

Due to the specific nature of agricultural production, the achievements of scientific and technical progress require the use of new techniques and technological means especially. This, in turn, requires the development of scientific and technical progress primarily for the development of productive forces and the emergence of new production relationships in the village. Scientific and technical progress in the agrarian sector, ultimately, requires intensive use of productive forces on the one hand, and on the other hand, the formation of productive relations. Scientific and technical progress in the agrarian sector is ultimately accompanied by intensive use of productive forces and, on the other hand, the improvement of production relations, which is considered as a crucial factor in increasing productivity.

Land plots that constitute the basis of agricultural production require high-mountainous, foothills and lay-outs to be used in a variety of areas.

It is one of the main conditions for the efficient functioning of the agrarian sector, with the introduction of new technologies in the production of entrepreneurship with the universal tractor, agricultural machinery and combines that can be used in all reliefs.

Land-climatic conditions in the conditions of new farming are based on the geographical structure of the republic, and the production of new productive and universal agricultural machinery is one of the most important challenges. This requires the improvement of the economic mechanism and serves the development of technical means that should be promoted in the sphere of influence of the economic mechanism in this area.

In the new farming environment, one of the important factors influencing the development of the agrarian sector is the material and technical resources market. The key factor here is the production and demand based production, the relationship between agricultural commodity producers and other consumers of the resource market, as well as the factor of price mechanism. The fact that this factor differs from other factors is related to the needs of agricultural producers in material and technical resources.

For this purpose development of mutual relations between producer and consumer is one of the most important issues. Establishing a proper proportion of the demand for material and technical resources has a profound impact on the efficient functioning of the agrarian sector. If the demand for material and technical resources increases sharply, or producers 
have limited access to it, then this trend is likely to lead to a reduction in the productivity of the production, causing the domestic market to frustrate and expanding the foreign market's business environment. In recent years, the agrarian crisis in the republic has slightly reduced production and has had a negative impact on the high prices, negatively affecting the material interest in this area, and the decline in production growth.

One of the key factors for the efficient functioning of the agrarian sector in the market economy is the technological factor. Technological factors are primarily related to the production of crops, livestock products, packaging and processing of agricultural raw materials, storage of commodities, technology for delivering them to consumers and so on. it applies. Technological factors affecting the agrarian sector may vary depending on regional characteristics, soil and climatic conditions, level of development of scientific and technical progress, demand factors.

As the market economy is based on the development of private institutions, it acts as a driving force, as a personal stimulus. Each peasant farm strives to produce products that are profitable, suggesting that maximizing profit or minimizing profit.

Owners of material resources attempt to earn higher profits as they lease or sell machinery and equipment. The peasant farms are often damaged and can not afford to pay for the production of inputs from the sale.

Thus, agricultural production is dependent on natural and climatic conditions, so producers can not handle the quantity and quality of the products to be marketed. This makes it difficult to forecast forecasts on supply and demand, and the amount and quality of products produced in non-normal soil climatic conditions are low. Naturally, this reduces the competitiveness of those products.

State-of-the-art measures have recently been undertaken by the state in order to meet the demand for agricultural commodity producers, regardless of their form of ownership, for material and technical resources. The Decree of the President of the Republic of Azerbaijan "On Additional Measures to Expand Leasing in the Agrarian Division" of October 22, 2004 is also of this nature. The order of the President of the country should be regarded as important in terms of adapting the economic mechanism of the material and technical resources market to the requirements of new production relations.

Expansion of agro-leasing activities will create conditions for the use of rental commodities from the logistics of agricultural commodity producers. In our view, implementation of this decree will play an important role in ensuring the agrarian sector's continuous technical resources.

\section{References:}

1. Degree of the President of the Republic of Azerbaijan dated October 22, 2004. On Additional Measures for Expansion of Leasing in the Agrarian Division.

2. Mammadov C. Organization of logistics and service work in the agrarian sector (textbook). 


\title{
Section 6. Economics, organization
}

\author{
Ivanova Snezhana, \\ Student 1 term, Faculty of Institute of philological \\ education and intercultural communication \\ Bashkir state pedagogical University M. Akmulla, Russia, Ufa \\ E-mail: snezhannaivanova18@mail.ru
}

\section{PROSPECTS OF RUSSIAN-SOUTH KOREAN ECONOMIC COOPERATION AND ANALYSIS OF WORLD MARKETS}

\begin{abstract}
The article deals with the current situation of Russian-South Korean cooperation on the world stage. The data on promising regions and needs of the Republic of Korea and comparative characteristics with the economies of other countries are presented. The current state of relations between our countries is analyzed, problems and prospects of cooperation are revealed.

Keywords: korean Peninsula, Democrac People's Republic of Korea, Republic of Korea, RussianKorean relatons.

The processes of globalization and regionalization of the world economy has led to the fact that no country has the world cannot help but feel their dominant influence both on their national economies, as well as its participation in the global production and exchange of goods. Russian-South Korean economic cooperation increasingly becoming addicted to these prevailing global trends, and its forms and formats correspond to the current state of the global environment. It should consider such specific factors as the North Korean vector in all its multifaceted significance, referring to security in Northeast Asia region and prospects of multilateral projects of mutually beneficial economic cooperation.

According to the International Monetary Fund (IMF) regarding the global economic outlook for 2013-2014. It is expected to moderate growth to $4.1 \%$ in $2014[1,23]$. This is a rather optimistic forecast, as early as 2012 the majority of international experts predict that in 2013 the modern model of the world economy will collapse exhausted all its

resources. The main cause of this collapse, according to a famous blogger Charles Hugh Smith $[2,56]$. May become a post-crisis monetary policy of central banks, which could not cure the economy, but only masked the symptoms of the disease. Nobel Prize winning economist Nouriel Roubini $[4,12]$ also warned of the risk of global economic recession.

Smith explained why economic models of the three centers of the world economy can no longer exist as before. For the countries of the Eurozone is perversity itself the European political and social model, where the state promises to the citizens social protection and high pensions, but to fulfill these promises cannot. In the foreseeable future, one can hardly wait for the collapse of the dollar as world reserve currency. It would be a disaster for the world economy, and especially for its major pillars: China, EU and Japan. In the future, the dollar could even be strengthened by increasing oil and shale gas, because in this case the United States will turn from an importer in the exporting country. Another reason to
\end{abstract}


strengthen the dollar - in a reversal of capital flows: 10 years, funds were sent from the US to China, and now China is suffering from capital outflows, which returns to the United States. Fundamental factors cause the dollar to rise. On the whole competition the dollar as a safe haven there. In September 2012 the US Federal Reserve (Fed) announced the start of the third program of "quantitative easing". With the increase in the money supply, the US government hoped to reduce interest rates on loans and, consequently, increase the demand for them. In other words, printing money would lead to active growth.

As for China, it has shown the world its own version of the economic miracle: for 50 years the country has become an industry giant. But the potential of its development is almost exhausted. Because of the recession in the USA and Europe, China's export machine fails, investments are falling, and internal imbalances and the bubble grows. The country's economy depends entirely on the investment, and the banks are actively investing in the development, did it with borrowed funds. Their default risks are growing exponentially. In general, the Chinese economy pushes dual mandate: growth at all costs, and maintaining social stability. In addition, China is on the verge of a natural disaster because of too ambitious infrastructure projects and high levels of pollution in the most industrialized areas in the east. In this way, model of world economic growth in recent years, based on the growth of US government debt and the rapid development of China, is losing its effectiveness. Meanwhile, the situation in these countries in the world economy at the end of 2013 shows that they are gradually released from the recession and competition between the United States and China continues.

The main events and trends in 2013 were:

- China the leading positions among the countries in the world in terms of foreign trade turnover. For the first time the United States had to give way to the championship on this indicator. In 2013, China's exports and im- ports of goods and services exceeded $\$ 4.16$ trillion $[9,16]$;

- The creation of a transatlantic free trade area between the United States and the European Union suspended. The reason - the United Europe considered undemocratic US foreign investment protection system;

- Intensified negotiations on a trilateral freetrade agreement between China-Japan-Republic of Kazakhstan, as well as multilaterally with ASEAN and Australia and India;

- Crisis continues in the US in the sphere of consumption; despite the attractive lending rates, Americans prefer not to buy and set aside funds;

- China began structural reforms of its economy. The conjuncture in world markets has not changed in favor of China, so the country's leadership sends its own reserves in the industrial sector tends to increase consumer activity of citizens;

- The most problematic situation in the Old World. The banking system of Europe is mired in debt, and eliminate them in a short time is not possible. For this reason, lending almost not developed, new jobs are created, which leads to an increase in unemployment, reaching in some countries $25 \%$, and deflation. At the same time the whole of last year the GDP of the euro area showed an increase of $0.5 \%$ (in 2012 there was a drop - minus $0.3 \%$ ) against the forecast of $0.4 \%$ [6]. The drivers became Germany's economy, France and Italy. In general, in the coming year to continue the trend of world economic growth sector, its stability is maintained. As the representative of JP Morgan Financial Corporation David Hensley, the world economy has increased in January by $3 \%$, and it continues to grow.

Experts believe that this year the rate of increase in China's GDP will not exceed 7,4\% [7]. One of the main reasons - slowing down investments. Analysts 
Organization for Economic Cooperation and Development (OECD) predict global changes in the world economy in the medium term: the next half century the combined GDP of China and India will exceed the aggregate GDP of the Group of Seven countries and even the countries of the OECD.

Thus, the developed economies of the world have demonstrated in a problematic situation, stability and ability to overcome the crisis. Locomotive out of the recession on a global scale once again become the United States. In Europe, the main role in this regard belongs to the economically stable Germany. As for Russia, then, according to the Ministry of Economy, for the period of 2012, the dynamics of GDP decreased approximately 4 times; the reason for this slowdown was the reduction of export volumes of energy resources and the reduction of consumer crediting.

The impact of global economic trends on the Russian economy is reflected in the following processes. After a brief period of hope for the revival of growth in 2011-2012. development of the economy has slowed dramatically. By the autumn of 2013 the scale of the problems in the Russian economy has reached such alarming proportions that it is possible to talk about the serious risks of a new recession. No less alarming is the situation in the external sector of the Russian economy. According to the Central Bank of Russia, for the first three quarters of 2013, exports of goods fell by $1.3 \%$ compared to the same period of 2012, but the share of crude oil, petroleum products and natural gas in the structure of exports reached a record level -67.3 $[5,16]$. Thus, the tendency to strengthen the raw materials orientation of Russian exports, which is characteristic for the entire period from the beginning of the global crisis, has received a new impetus in 2013. Parallel to this, the net outflow of capital from the private sector in the same year reached US $\$ 48.1$ billion., Reflecting a further reduction in the resources potentially available for investment in the Russian economy.
A combination of internal and external factors suggests that the model of economic growth based on the use of revenues from energy exports to boost consumer and investment demand, once again fails. In this case, the sharp slowdown in the Russian government threw a double challenge: to ensure implementation of initiatives taken in a period of hope for a speedy overcoming the consequences of the crisis, and at the same time to prevent the sliding of the economy into a new recession. In 2012, the President of the Russian Federation's strategic objective of improving the investment climate has been set, according to which Russia will rise from $120^{\text {th }}$ place in the ranking of Doing Business World Bank in 2011 to 50 ${ }^{\text {th }}$ in 2015 and $20^{\text {th }}$ place - in 2018. According to this ranking, at the June 2013 Russia ranked $92-^{\text {th }}$ place, i.e.

Despite the economic downturn, in 2013, there has been impressive growth in foreign direct investment. In January-September, the country received more than one and a half times more foreign investment than for the entire 2012 - compared with $\$ 42.8$ billion to $\$ 66.0$ billion, however, the structure of these investments has remained traditional: More than half falls on the trade and real estate operations, more than $60 \%$ came from Cyprus and the Netherlands. Another disappointment was the absence of a positive outcome of accession to the WTO both in terms of improving the business climate in Russia, and in terms of its trade and investment relations with foreign partners.

According to the survey, conducted by the Russian Union of Industrialists and Entrepreneurs, only $1 \%$ of companies feel the change for the better, $13 \%$ for the worse, and about $86 \%$ did not felt the effect of accession. The development of the Russian economy in 2012-2014. due to the completion of post-crisis recovery and the transition to the implementation of the strategic nature of the objectives enshrined in the concept of long-term socio-economic development of Russia for the period up to 2020. The main risks for the Russian economy in the period associated with the global economic instability, causing a 
slowdown in global economic growth, increase the risks of the negative dynamics of oil prices and increased capital outflow, which in turn will lead to lower investment demand, contraction of lending, worsening NIJ fiscal positions. Increasing the efficiency of the economy in the period 2012-2014 biennium. is largely determined by a positive contribution to the implementation of government programs and measures aimed at supporting the development of key economic sectors, especially high-tech industries, as well as the fulfillment of the state defense order, which in 2012-2014. directed about 2.7\% GDP. To finance the complex of programs and measures for the development of the transport system receives about $1.2 \%$ of GDP.

Modern trends and challenges of the global economy have a corresponding impact on the cur- rent state of Russian-South Korean cooperation. This is determined by the influence of a number of factors:

1) the dynamics of growth and foreign demand;

2) enhancement or suppression dollar;

3) the dynamics and direction of movement of international capital;

4) changes in the global pattern of economic growth;

5) a change or adjustment of national economic development models;

6) the phase of the development cycle of the world capitalist;

7) domination of the interests of economic cooperation with major trading partners (for the Republic of Kazakhstan - China, for Russia - the EU, the CIS, China).

\section{References:}

1. Gazprom-LG International: promising! // URL: www.neftegaz.ru/lenta/show/37906 (reference date 25.10.2010)

2. Charles Hugh Smith (Charles Hugh Smith) - a popular American blogger and economist. Author of eight books published in the United States.

3. CORINTH. 2005.- No. 30.

4. Nouriel Roubini, chairman of Roubini Global Economics, Professor Stern School of Business at New York University (C) Project Syndicate, 2013.

5. Prospects of development of the Russian economy in 2014. URL:http://www. webeconomy.ru/index.ph

6. Republic of Korea - the economy and relations with Russia torgovoekonomicheskie // Foreign Commercial Information Bulletin.- No. 139.- 3 December, 2005.- C. 3. (Reference date: 06/10/2019).

7. Russia cooperation prospects and Korea in the field of energy discussed by the participants of the sixth meeting of the Russian-Korean Committee. 15.07.2005 // URL:http://www.fcinfo.ru/themes/basic/ ma-terials-document.asp folder $=144 \&$ matID $=73895$ (da-ta treatment 25.10.2010).

8. Russian-Korean trade grew by $38 \%$ to $\$ 5.8$ billion // URL:http://Www.csr.ru/publication/original 551 / stm (reference date 25.10.2010).

9. The World Economy: Trends and Prospects. URL:LIGA BusinessInform. Information Agency URL: http://www.liga.net (Reference date: 06/10/2019). 
Syaparman,

Sri Suwitri,

Etty Sosilowati,

Hartuti Purnaweni,

Public administration doctoral program

Faculty of social and political sciences

Diponegoro university, semarang, Indonesia

E-mail:prodidap@gmail.com

\title{
SUPPORTING AND RESTRICTING FACTORS OF CORPORATE SOCIAL RESPONSIBILITY (CSR) PROGRAM OF POLICY IMPLEMENTATION AT THE COAL MINING COMPANY IN LAHAT DISTRICT
}

\begin{abstract}
CSR Program is an investment for the company. Sustainable growth no longer considered as a center of cost (cost centre) but as a means to benefit (profit centre). CSR Program is a commitment of the company to support the creation of sustainable development. The impact of CSR for all companies in the world depends on the nature of the company. Based on The research on The Millennium Poll on CSR (1999) conducted by Environics International (Toronto), Conference Board (New York) and Prince of Wales Business Leader Forum (London). It was explained that 25.000 respondents in 23 countries showed that In shaping opinions about the company, $60 \%$ of respondents said that business ethics, employee practice, environmental impact, corporate social responsibility (CSR) will be the most instrumental, while for $40 \%$ of respondents say That the company image \& brand image will most influence their impression. In implementation analysis, there are two approaches, namely, the first, the compliance approach. Second, what perspective is going on? This approach sees the implementation of a policy of all things, assuming policy implementation involves and link by all sorts of variables and factors. The implementation of the policy is an evaluation analysis, with the consequences of more reviews that returning from a prospective that has a purpose. Namely: (a) providing information to (the) policymakers on how to Their programs are underway or executed and (b) demonstrate factors that can become advocates and barriers in the process of implementing CSR program policies, to then provide alternative new policies or find ways Other implementations.

Keywords: CSR, Sustainable Grpwth, Company Image, Brand Image and Policy Implementation.

\section{Introduction}

The Corporate Social Responsibility abbreviated as CSR Program has begun to emerge in Indonesia since its disappearing in (Republik Indonesia, 2007) about the Limited Liability Company and (Indonesia, [1]) on capital investment. The contents of the law relating to the CSR, namely in Law of Article 74 (Republik Indonesia, 2007), stated: 1) the company that conducts its business activities in the field

and/or related to natural resources must carry out the responsibility Social and environmental responsibilities; 2) Social and environmental responsibility as referred to in paragraph (1) shall constitute the obligation of the company, which is considered and accounted as the cost of the company in which the implementation implemented by paying attention to the compliance and fairness; 3) The company that does not carry out the obligations referred to
\end{abstract}


in paragraph (1) sanctioned according to the provisions of legislation; 4) Further provisions on social and environmental responsibilities governed by government regulations.

Corporate Social Responsibility (CSR) Program is an investment for the company. Sustainable growth no longer considered as a center of cost (cost centre) but as a means to benefit (profit centre). CSR Program is a commitment of the company to support the creation of sustainable development. On the other hand, the community questioned whether the company that is oriented towards the efforts to maximize the profit has a moral commitment to distribute part of its profit to build local communities. Because along with The passage of time society no longer merely demands companies to provide the goods and services they need, but also demands the company to be responsible for their social and environmental problems.

The impact of CSR for all companies in the world depends on the nature of the company. Based on The research on The Millennium Poll on CSR (1999) conducted by Environics International (Toronto), Conference Board (New York) and Prince of Wales Business Leader Forum (London), it was explained that 25.000 respondents in 23 countries showed that In shaping opinions about the company. $60 \%$ respondents said that business ethics, employee practice, environmental impact, corporate social responsibility (CSR) will be the most instrumental, while for $40 \%$ of respondents say That the company image \& brand image will most influence their impression. Only $1 / 3$ underlies its opinion on fundamental business factors such as financial factors, company size, corporate strategy, or management. Further, the attitude of consumers to companies that judged not to do CSR is to want to "punish" (40\%) and 50\% will not purchase products from the company in question and talk to others about the shortage of such companies.

According to previous research such as research by: (Yaparto K., \& Eriandani [19]), the research results showed some programs still have not seen the principle of transparency, accountability, responsibility, independency and fairness in CSR programs that have been conducted. Implementation of CSR program has not supported by management because the company does not have planning and budgeting for CSR activities. Later research by Jiuhardi, [3] concluded some things, namely CSR has been generally done well by the coal mining company, but a small part is doing well, most are still lacking and even impressed The implementation of random, it is caused by the condition of the company underprivileged and the rules on the implementation of CSR is unclear.

Similarly, research by (Thionardo \& Goestaman [14]), concluded that the planned CSR program almost entirely can be implemented, however in the implementation there are still weaknesses, so the results of Its implementation is not maximized. (Sari, Mulyana, \& Alfitri [11]), showed that the implementation of environmental CSR program PT Semen Baturaja (Persero) TBK can be concluded that the implementation of environmental CSR program PT Semen Baturaja (Persero) TBK influential Social economic conditions in the ring area I of Ogan Komering Ulu regency.

The growth of the coal industry has grown considerably in the past 10 years. Until 1997, Indonesian production amounted to 13.2 million metric tons and increased by 3 times or 243 percent in 2007 to 53.3 million metric tons. In 2007, Indonesia listed as the seventh largest coal producer in the world, and placed $2^{\text {nd }}$ as a coal exporter with total exports of 202 million metric tons. State revenues from the coal sector continue to experience a significant increase from year to year. It is starting from 2.57 trillion in 2004 to 8.7 trillion in 2007. In 2009, the contribution of coal recorded more than 10 trillion (Office Department of Mines and Energy in Lahat District, 2013).

Furthermore, the results of the survey conducted by (Suprapto [12]) against 375 companies in Jakarta said: that $166(44.27 \%)$ The company does not conduct CSR and as much as 209(55.75\%) the company that conduct CSR. The CSR that implemented by 
the company depends heavily on the company's own management desires.
CSR programs in several coal-mining companies in Lahat district are as follows:

Table 1.- CSR Program of coal mining company in lahat regency of south sumatera province

\begin{tabular}{|c|c|c|}
\hline No & Company Names & CSR Programs \\
\hline 1. & PT.Aman Toebilah Putra & Not programmatic \\
\hline 2. & PT.Andalas Bara Sejahtera & Not programmatic \\
\hline 3. & PT.Batubara Lahat & Not programmatic \\
\hline 4. & PT.Bumi Merapi Energy & Not programmatic \\
\hline 5. & PT.Duta Alam Sumatera & Environmental Conservation Campaign \\
\hline 6. & PT.Golden Great Borneo & Not programmatic \\
\hline 7. & PT.Muara Alam Sejahtera & $\begin{array}{l}\text { 1. Natural Disaster Relief } \\
\text { 2. Green Program }\end{array}$ \\
\hline 8. & PT.Mustika Indah Permai & $\begin{array}{l}\text { 1. Natural Disaster Relief } \\
\text { 2. Green environment } \\
\text { 3. Environmental Conservation Campaign }\end{array}$ \\
\hline 9. & PT.Dizamatra Powerindo & $\begin{array}{l}\text { 1. Environmental campaigns } \\
\text { 2. Participation in World Environment Day } \\
\text { 3. Disaster Management Fund }\end{array}$ \\
\hline
\end{tabular}

Source: Office Department of Mining and Energy of Lahat District (2015)

Decision-making by the management of the company to implement CSR programs sustainably is essentially a rational decision. Because CSR implementation programs will create a golden circle effect that can enjoyed by the company and its stakeholders. Through CSR programs, welfare and socio-economic life of local people and the wider community will be better. This condition in turn will ensure the smooth running of all processes or production activities of the company until the marketing of production results.

If take an attention to the above table of programs, it can be concluded that some coal mining companies ( 4 companies) existing in Lahat District that already have CSR program, and some $(5 \mathrm{com}$ panies) do not have a CSR program. In addition, the public largely not understanding the CSR program, because there is no socialization of CSR programs both from the government and from the company itself. Thus, it interpreted that people have not been able to benefit from the CSR program maximally.

\section{Literature review}

Bases on the results of some studies above concluded that the CSR implementation program are giving very beneficial for the welfare of society even though its implementation randomly. Therefore, so that the management of coal can run well in accordance with the prevailing laws and regulations, the Government must act firmly against the entrepreneurs, should not exploited by persons who are not responsible Answer. Thus, the Government as a trustee in granting permits to the mining Power Holders $(K P)$ that conducts coal mining in Lahat District must pay attention to social and environmental responsibilities known as CSR Especially in the environment. Because the impact of the company's coal mining in this area is enough to worry mainly because of transportation using truck vehicles, so that almost along the way that the coal trucks are damaged condition. Together with the flying dust and the sound of the engine that are whises the ears. This is the necessary implementation 
of CSR program policies by minimal companies to minimize the impact of environmental damage and reduce pressure and friction with the surrounding community.

\section{Policy Implementation}

The implementation of the policy is an evaluation analysis, with the consequences of more reviews that returning from a prospective that has a purpose. Such as: (a) providing information to (the) policymakers on how to Their programs are underway or executed and (b) demonstrate factors that can become advocates and barriers in the process of implementing CSR program policies, to then provide alternative new policies or find ways Other implementations.

In implementation analysis, there are two approaches, namely, first, the compliance approach. This approach assumes that the policy implementation will succeed if the perpetration adheres to the instructions provided by the upper bureaucracy that establishes the policy. Second, what perspective is going on? This approach sees the implementation of a policy of all things, assuming policy implementation involves and link by all sorts of variables and factors. Thus, what is involved and takes place in the implementation is far more important captured and examined than to be in the implementation of the appropriate necessity. (Nugroho [8]) suggested that: "policy implementation in principle is a way that a policy can achieve its objectives. They are no more and no less. In order to implement public policy, there are two options to implement, directly implementing in the form of programs or through the formulation of derivate policies or derivatives of these public policies".

Implementation is one of the dimensions in the public policy process that strongly determined whether a policy is in contact with the interests and accepted by the public. According to (Van Meter \& Van Horn [16]) in (Landiyanto [6]) defined "the policy implementation as an act which is performed either by individuals or officials or government or private groups directed at the Achieving the objectives outlined in the policy decision".
In an implementation, it is necessary for a clear device to run the implementation function effectively so that the expected objectives are able to materialize according to what has expected. According to the (Wahab [17]) in his book explained that: "The function of policy implementation was to create a relationship that greatly allows the objectives or objectives of the State policy to be implemented and manifested as outcomes (End result) of the final activities desired by the Government. Therefore, implementation functions include the formulation of what is in the science of the State policy is called policies delivery system (System delivery/forwarding State policy) Usually consists of specific means or objectives designed/ Designed specifically and directed toward the achievement of the objectives and intended objectives".

\section{Policy Implementation Elements}

There are many theories about implementing policies describing a number of factors that can affect the success of implementing a public policy. (Thornton III \& Thornton [15]) in the book, Implenting Public Policy reveals policy communication has several kinds of dimensions, among others: dimension of transformation or delivery of public policy information, clarity, and consistency. The better coordination of communication among the parties involved in an implementation process, the mistakes will be very small to occur and vice versa. Implementation is an activity that has three essential and absolute elements in running it. The elements of the implementation of the policy include (Wahab [17]): 1) The existence of programs implemented; 2 ) the presence of target groups, which is the target community and hopefully will benefit from the program; 3 ) the implementation of, Either an organization or individual responsible for the management, implementation or supervision of such application process. Based on the above understanding, the implementation of the element is the program, target and implementation in realizing the desired objectives. Therefore, that in the implementation is a little possible error, if there is a mistake then realized quickly. 
(Van Meter \& Van Horn [16]) had some elements that may affect an organization in implementing the policy. They are consists of: 1) The competition and the size of the staff of the body; 2) the level of hierarchical supervision of sub-unit decisions and processes in implementing agencies; 3) Political resources of an organization (e.g. support among members of legislative and executives); 4) Vitality of an organization; 5) The "open" communication level, which is defined as the free horizontal and vertical communication network and the level of freedom that is relatively high in communication with individuals outside the organization; 6) Formal and informal linked of a body with a "decision-maker" or "decision-making" body. The opinions expressed by (Van Meter \& Van Horn [16]) were very important, because the performance of implementation is strongly influenced by the nature or characteristics of the executive. If the implementation has good properties or characteristics, then it will be able to run the policy well as what the policymaker wants in assessing the success performance of the policy implementation. (Lawler III \& Worley [7]) attempted to answer these two questions by reviewing four factors or variables from the policy of bureaucratic structure, resources, communication, and disposition.

According to (Keraf dan imam [6]), in connection with the CSR, as far as it is considered a value and mission to be realized, the social audit intends to assess and measure the performance of the company in relation to various social issues that the company wants to overcome. Based on the explanation above, it seen that CSR is a set of policies and programs integrated into the company's business activities that implemented through the following process:

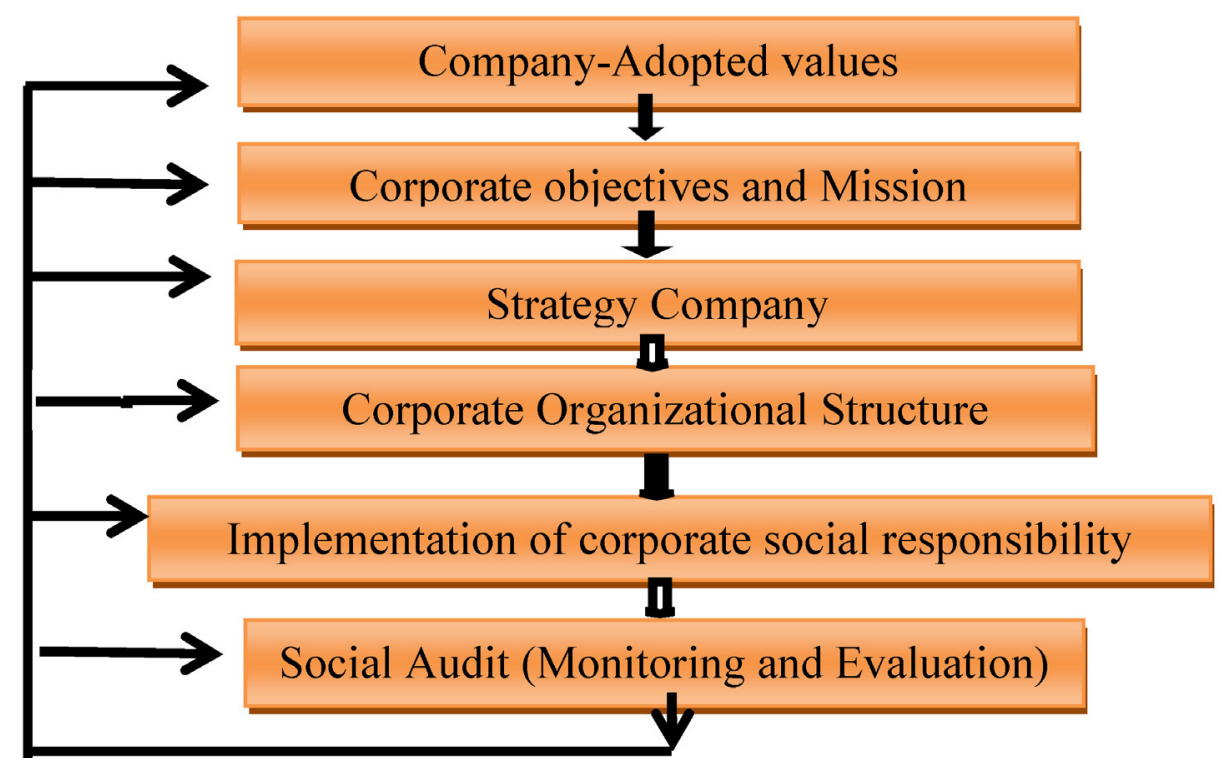

Figure . CSR Implementation Process

Source: CSR Implementation Process (Keraf \& Dua [5])

According to (Keraf \& Dua [5]) explained that the principles of business ethics are as follows:

1. An Autonomy Principle; that is the attitude and ability of people to make decisions and act on their consciousness of what they think is good to do.

2. Principles of Honesty; There are three scope of business activities that can be clearly demonstrated that the business will not be able to last long and suc- ceed if it is not based on honesty. First, be honest in fulfilling the terms of agreements and contracts. Secondly, honesty in the supply of goods or services is with quality and comparable price. Third, honest in the internal is working relationship within a company.

3. Principles of Justice; Demanded that everyone be treated equally in accordance with the fair rules and appropriate objective rational, and accountable. 
4. Mutual Benefit Principle; demanded that the business be executed in such a way that it benefits all parties.

5. Principles of Moral Integrity; primarily internalized as internal demands within businesses or corporations, in order to run the business while maintaining the name of either its principal or its people or the company.

\section{Research method}

Based on the research problems described earlier, the approach used in this research is a qualitative descriptive approach for reviewing supporting factors and inhibiting in implementing CSR program policies. Coal mining company in Lahat District conducted the location of this research. Research site determination based on the conditions of the problem faced, especially about the implementation of CSR program policies. The study used time for 2 years.

This research related to the implementation of CSR program policy by coal mining company in Lahat District. Implementation of CSR program policy researched based on (Van Meter \& Van Horn [16]).

The data used in this study are as follows: primary Data through informants who know deeply the problems studied in this study, including public policy experts, executive apparatus/implementing personnel, communities that every day applies for building permits, as well as other informant that will be found in the field and have knowledge with the issues studied. The primary data referred to in this study is a literature that contains data relating to the issues studied in this study, including data on the implementation of CSR program policies, various obstacles faced in implementing The CSR program policies and other relevant secondary data.

The data collection procedure used in this research includes several steps: Observation, interview, and documentation. Data analysis techniques through data obtained in the field analyzed in a descriptive. Descriptive analysis intended to illustrate the various conditions of supporting invoices and barriers in the implementation of CSR programs. In analyzing the data as (Ridder, Miles, Michael $\mathrm{Hu}$ berman, \& Saldaña [10]) which stated that in the analysis of qualitative data there are three threads of activity occurring together.

\section{Result and discussion}

The focus of this research is how the implementation of CSR program policy and supporting invoices and the inhibitors faced in the implementation of CSR program policy in Lahat District. It is as well as the posting of this Conversation is expected to occur Improving the implementation of CSR programs from year to year, therefore to achieve success in implementing regional policies need to improve all the shortcomings and constraints faced in implementing the policy. It is such as by improving facilities and infrastructure, how CSR management, implementing capabilities, human resources, bureaucratic structures and good communication in achieving the realization of CSR programs annually.

\section{Policy implementation of CSR program}

Lahat District government has shown seriousness and commitment in handling CSR activities, proved by the issuance of regent Regulation No. 30 year 2015 on CSR and PKBL, and decree of Regent No. 194. In 2015 on the establishment of CSR Forum execute in Lahat District. Implementation of CSR program policy in Lahat District government, get full support from the coal mining company, this is evident from the results of interviews to three leaders of the company stating that their company has done CSR activities that guided by applicable laws and regulations.

\section{Supporting factor of CSR Policy Imple- mentation}

The implementation of CSR program policy in Lahat District received support from several parties of academics, practitioners and entrepreneurs and society, but there is also a inhibitory factor. The implementation of the policy (Van Meter \& Van Horn [16]), formulated the existence of 6 (six phenomena) that affect the outcome of the policy implementation namely: 1) Size and purpose of policy; 
2) Resources; 3) Characteristics of implementing agen; 4) Attitudes/tendencies of the executor; 5) Communication is between organization and implementing activities and; 6). Economic, social and political environment. Aside from the above 6 (six) factors that have a major influence on CSR programs are entrepreneurs ' awareness factors, deregulation factors, organizational factors, entrepreneurs advantage factors, skills and facilities and infrastructure factors.

\section{Measurement and aim of policy}

(Tampubolong [13]) said the performance of policy implementation can be measured the success rate of the size and objectives of the realistic policy with Sosio-kultur at the policy executor level. When the size and target policy is too ideal (utopis), it will be difficult to realized.

In implementing CSR program policies, the size and objectives that want achieved is quite clearly contained in the rule of Regent Number 30 year 2015, which is a clear boundary of the CSR program. The implementation of CSR programs are in accordance with Legislation, realization of legal certainty and protection, protecting the company from wild levies, programmatic regional government plans, as well as guidance for the organizers of CSR programs by companies operating in Lahat District. The implementation of CSR program is a company that is legal status and not differentiated between private and state-owned companies and/or the property of the District government that produces goods and services with the target area of CSR programs prioritized for the areas directly impacted by the company's operations.

\section{Implementer agent characteristic}

The behavioral tendencies or characteristics of policy executor play an important role in realizing the policy implementation in accordance with objectives. Important characters that owned by policy executor e.g. honesty and high commitment. Honesty directs the implementation to remain in the outlined program, while the high commitment of policy executor will make them always enthusiastic in carrying out the duties, authorities, functions, and responsibilities in accordance with predefined regulations. Hearken to the interviews to three leaders of coal mining companies who acknowledge the commitment, caring and honesty of the political leadership in this case the local government of Lahat Regency and Regional Representative Council (DPRD) that became its own motivation for the company to contribute to supporting the implementation of CSR program policy in Lahat District.

\section{Economy, social, and politycal environments}

Environmental conditions where policy implemented greatly affect the success of policy implementation. Although the impact of this factor does no too big but it may have a profound effect on achieving the policy governing body. The social, economic, and political environment that is not conducive can be a failure effect of the policy implementation performance. Therefore, efforts to implement the policy should also pay attention to external conducive environmental conditions. Listen to the interview results concluded that the implementation of the CSR program policy in Lahat District has indicated strong support from the social, economic, and political environment.

\section{Communication among Agents}

Good relations between organizations and intergovernmental also facilitate policy implementation. Advice, suggestion, or technical assistance provided assists in interpreting regulations and government guidelines that are useful in implementing policies and sanctions both positive and negative given if there is a something that felt is not appropriate in the original purpose. Policy communication means the process of conveying policy information from policy maker (policy maker) to implementing policy (implementer) (Widodo [18]) In the hope of communication, all can walk according to the plan so that the desired objectives achieved.

\section{Resources}

The limitations of time, money, and other resources must always be aware of their existence and 
influence (Jefkins \& Jefkins [2]). Resources have an important role in policy implementation. The resources here relate to all sources that used to support the success of policy implementation. These resources include human resources, budgets, facilities, information and sufficient authority available for the implementation of the CSR program policy of the coal mining company in Lahat District.

\section{Vission and mission of the company}

The implementation process seen from the company's objectives is to seek maximum profit with the vision of establishing good relations with the Community and government, making the company a national scale and beneficial to the people many. The company's mission indicates that the company has a concern for its responsibilities, social, economic and environmental. The company's step in realizing its mission through human resources development, helps with the community, and improve Stakeholders 'role. The coal mining company in Lahat District has been concerned about the needs and interests of the community, especially the communities around the mine site. The company's relationship with the community is well-established symbiotic mutualism.

\section{Company Strategy}

Strategy includes the development of vision and mission, identification of the opportunities and external threats of an organization, awareness of internal strengths and weaknesses, long-term goal setting, strategy alternative Search, and selection of certain strategies to reach the goal. In observing the strategy then taken by the coal mining companies seen from the results of interviews in the previous chapter. Based on the results of the interview can be concluded where the coal mining company in Lahat district has a proactive strategy. The company considers that social responsibility is part of the responsibility to satisfy stakeholders. If the stakeholders are satisfied, the positive image of the company awakened. Implementation of corporate social responsibility or corporate social responsibility program can make a positive impact on the company.

\section{Company organization structure}

The organizational structure of the coal mining company arrange by a President Director. Furthermore, President Director assisted by four directors, namely Finance Director, Commercial Director, Technical Director, and Human Resources director. Meanwhile, a General Manager leads each branch or operating unit. Management of CSR program is under Public relations management under the control of Human Resources Director. As a form of alignments towards social and environmental problems and the inevity of the negative impact of the company's existence, the social responsibility implement in a well-planned environment. Therefore, in order to maintain the implementation of social responsibility carried out seriously and well planned, it is necessary to be formed a department that is especially responsible for the implementation of social responsibility.

\section{Conclusion and suggestion}

From the results of the research and discussion have explained earlier they are consist of a conclusion that the local government of Lahat district. in the implementation of CSR program policy can be analyzed by the conclusion of implementation of CSR program policy already in Implemented in the local government of Lahat district. It continued and the implementation shows a tendency to better attitude, although found barriers in coordination between the implementing agents and the delegation of Management Authority CSR program from the government to the CSR Forum.

Based on the results of the above studies, it suggested that in implementing CSR program policy integrated in one container, namely the CSR Forum to make improvements to the various parties as follows:

\section{1) Regional government of Lahat District}

a. Communicating the CSR program policy to all executors to make a new breakthrough in overcoming the weakness of policy communication from the Government, thus enabling implementation of 
the policy will be better. Socialisai policy of Regent Regulation No. 30 in 2015 about CSR and the decree of Regent Number 194 a year 2015 about Forum CSR should further improved.

b. Resources adjusted to the need for the implementation of CSR program policy that is adequate human resources and competency in the field of CSR. The physical facilities, especially information technology, integrated with all stakeholders, so it is easily accessible to the importance of policy implementation.

c. The commitment of local leadership to support the implementation of policies, supporting positive attitudes both from internal and external parties in implementing CSR program policies.

d. Implementation of CSR program policies to continue followed and evaluated periodically, so that the implementation of CSR program policy will be better in the future.

e. Implementing agency CSR Forum is an employee who given the task of implementing the CSR Forum, does not have a double position in the government.

\section{2) CSR Forum in Lahat District}

a. In conducting communication policy, execute by the local government as a motivator, counselor, facilitator and mediator between the government and the company.

b. In reviewing CSR policy in Lahat District in the planning efforts aims to develop a participatory, accountable and transparent CSR, program.

c. CSR Forum in order to have its own office and/or secretariat, they also can run a forum task in CSR planning.

\section{3) Coal Mining Company}

a. Conducting policy communications to the local government implement by providing adequate facilities and assigning competent employees to perform good policy communications.

b. Evaluate the implementation of CSR policy program to be better, clear, understandable, and measurable in arranging, organizing and designing activities in the CSR program.

c. Socialize policies to all employees for the support and uniformity of thinking patterns and actions in CSR activities.

\section{References:}

1. Indonesia P. R. UU Nomor 25 Tahun 2009 Tentang”Pelayanan Publik”. UU Nomor 25 Tahun 2009. Tentang Pelayanan Publik.

2. Jefkins F., \& Jefkins F. Marketing Research. In Modern Marketing Communications. 2012. URL: https://doi.org/10.1007/978-94-011-6868-7_22

3. Jiuhardi. Tanggung Jawab Sosial Dan Lingkungan Perusahaan Pertambangan Batu Bara Dalam Upaya Meningkatkan Kesejahteraan Masyarakat Kutai Kartanegara. Forum Ekonomi. 2012.

4. Keraf A. S., \& Dua M. Ilmu Pengetahuan Sebuah Tinjauan Filosofi. kanisius. 2001.

5. Keraf dan imam. Persepsi Akuntan, Mahasiswa Akutansi, dan Karyawan Bagian Akutansi dipandang dari Segi Gender Terhadap Etika Bisnis dan Etika Profesi (Studi di Wilayah Surakarta). Simposium Nasional Akuntansi, 2006.

6. Landiyanto E.A. Spesialisasi dan Konsentrasi Spasial Pada Sektor Industri Manufaktur di Jawa Timur. In Paralel session VIB: Industry and Trade. 2005.

7. Lawler III E.E., \& Worley C.G. Designing Organizations That Are Built to Change. MIT Sloan Management Review. 2006.

8. Nugroho R. Public Policy: Dinamika Kebijakan, Analisis Kebijakan, dan Manajemen Politik Kebijakan Publik. Jakarta: Elex Media Komputindo. 2017. URL:https://doi.org/10.1017/S0033291702006190 
9. Republik Indonesia. Undang-Undang Republik Indonesia Nomor 40 Tahun 2007 Tentang Perseroan Terbatas. Www. Hukumonline. Com. 2007.

10. Ridder H. G., Miles M. B., Michael Huberman A., \& Saldaña J. Qualitative data analysis. A methods sourcebook. Zeitschrift Fur Personalforschung. 2014.

11. Sari E. K., Mulyana A., \& Alfitri A. Implementasi program csr lingkungan pt. Semen baturaja (persero) Tbk Terhadap Kondisi Sosial Ekonomi Masyarakat Di Kabupaten Ogan Komering Ulu Sumatera Selatan. Jurnal Ilmu Lingkungan. 2017. URL:https://doi.org/10.14710/jil.13.1.42-52.

12. Suprapto. Pengaruh Disiplin Kerja dan Lingkungan Kerja Terhadap produktivitas Kerja Karyawan bank bri syariah Kantor cabang pembantu genteng banyuwangi. Jurnal Hukum Islam, Ekonomi Dan Bisnis. 2016. URL:https://doi.org/2460-0083

13. Tampubolong A.P. Kajian Kebijakan Energi Biomassa Kayu Bakar (Study of Fuelwood Biomass Energy Policies). Analisis Kebijakan Kehutanan. 2008.

14. Thionardo R., \& Goestaman I. Evaluasi Peran Sistem Pengendalian Manajemen Untuk Meminimalkan Konflik Pada Badan Usaha Keluarga “K” di Tulungagung. Calyptra. 2017.

15. Thornton III, \& Thornton G. C. Concepts and Principles. In Developing Organizational Simulations. 2018. URL:https://doi.org/10.4324/9781315652382-1

16. Van Meter D. S., \& Van Horn C.E. The Policy Implementation Process: A Conceptual Framework. Administration \& Society. 1975. URL:https://doi.org/10.1177/009539977500600404

17. Wahab S. A. Analisis Kebijaksanaan: Dari Formulasi ke Implementasi Kebijaksanaan Negara. Jakarta: PT. Bumi Aksara. 2004.

18. Widodo N.M. Pengaruh karakteristik perusahaan terhadap pengungkapan akuntansi sumber daya manusia. Simposium Nasional Akuntansi 17 Mataram, Lombok. 2014.

19. Yaparto M. K., D.F., \& Eriandani R. (2013). Pengaruh Corporate Social Responsibility Terhadap Kinerja Keuangan Pada Sektor Manufaktur Yang Terdaftar Di Bursa Efek Indonesia Pada Periode 2010-2011. Jurnal Ilmiah Mahasiswa Universitas Surabaya. 


\title{
Section 7. Economic security
}

\author{
Dadashova Jala Bayram Qizi, \\ Doctorate at the Azerbaijan Cooperation University \\ E-mail:haciyeva_gulnara@mail.ru
}

\section{INFLUENCE OF FOREIGN TRADE RELATIONS ON PROVISION OF AZERBAIJAN'S ECONOMIC SECURITY}

\begin{abstract}
The dynamics of the socio-economic development of the country is a prerequisite for ensuring its economic security. The economic security of each country depends on the level of its economic development. In order to ensure sustainable economic development in the country, problems encountered in domestic and foreign trade should be solved in a timely manner. The article lists internal and external economic factors affecting Azerbaijan's economic security. The parameters required for the economic security of the Azerbaijani state are indicated. Taking into account the participation of the Republic of Azerbaijan in international economic relations as one of the main economic risks, export balance is export oriented at the expense of raw materials, and food provision is provided by import.
\end{abstract}

Keywords: economic security, foreign trade, import, export, food balance, non-tariff regulation, agricultural products.

The dynamics of the socio-economic development of the country is a prerequisite for ensuring its economic security. The economic security of each country depends on the level of its economic development. In order to ensure sustainable economic development in the country, problems encountered in domestic and foreign trade should be solved in a timely manner. Otherwise, these problems can become a source of danger for the country's sustainable development. The experience of the world's developed countries makes it possible to conclude that the problem of economic security has now become an integral part of the foreign and domestic trade policies of the countries.

Ensuring economic security reflects a state of the economy that no threats are expected from the inside or outside of the country, preventing its sustainable development. In the event of an inadequate develop-

ment of internal and external processes, there are sufficient defensive resources in the country to protect national interests. While the problem of economic security and its solutions are typical for all countries, the parameters of its security are not the same for all states. This is due to the fact that external and internal factors that guarantee the country's economic security are not shared or distributed equally in all countries.

Internal and external economic factors affecting Azerbaijan's economic security can be grouped into two main groups:

1. Natural factors: the existence of the natural resources available to the country, its geographical position, the state of labor resources, etc.

2. Economic factors: the level of market economy and its infrastructure, the place of the country in the international division of labor and the integration 
into world countries, the level of economic resources utilization, integrity of the territory, the completeness of the economic space and reprocessing process, the competitiveness in international markets.

The extent and structure of its natural resources is the main factor of the state's economic security. Countries with richer natural resources do not invest heavily in ensuring economic security. Azerbaijan is also a group of countries with rich natural resources. The first group factors are very characteristic of Azerbaijan's economy. Production of goods and services is carried out using the production factors formed with the help of natural resources, high skilled workforce, scientific and technological progress and human capital. It should be borne in mind that, in some scientific studies on national economic development and growth, the abundance of natural resources has a negative impact on economic development and progress.

From the experiences of countries around the world, certain processes occurring in the country can also pose a threat to such processes as:

1. Reducing the level of economic growth in the country and reducing domestic demand through more imports;

2. The decline in the living standards of the population, the increasingly unemployed army and the poor;

3. Violation of foreign trade balance and increase of import specific weight;

4. Irreversible character of corruption in the country, economic crime;

5. Investment policy does not meet the required requirements, limits of foreign investment in the economy of the country;

6. Improper monetary policy and increased inflation risks;

7. The decline in the production of foodstuffs, the need to meet the demand for imports;

8 . State reserves are not adequate;

9. The State's non-expenditure of revenues from strategic economic sectors is less cost effective and appropriate;
10. Corrective of structural reforms, violation of balance between economic structures and its onesided development;

11. Decrease in investment and innovation activity and optimal use of scientific and technical potential;

12. Increase in foreign debt, foreign currency outflows, excessive economy, etc.

All of these can lead to a breakdown of economic stability in the country, a sharp decline in the living standards of the population, financial crises and other unpleasant consequences. Therefore, it is important that each of these factors be considered in the focus of the economic security strategy. [1, P. 28]

Based on world practice, economic security strategies of various countries, as well as software projects developed by Azerbaijani specialists, the parameters of the state's economic security can be coordinated with the following sequence:

Logical sequence of parameters required for the economic security of the Azerbaijani state.

Only economic security can be said about the existence of the parameters. Exactly ensuring that all these parameters are properly maintained can provide the economic security of the Azerbaijani state [2, p. 62-63]. Most of these are expressed in concrete numbers in each country: for example, inflation should be up to $3 \%$, the budget deficit should not exceed 3\% of GDP, 30\% of domestic debt, the debt is $30 \%$ of GDP and $25 \%$ of fixed capital investments are considered acceptable.

In a globalized world in modern times, the economic security problems of each country are intensifying. So much depends on the productivity of production and consumption, such as the competitiveness of commodities and services, including the sharpening of specialization in the international division of labor, the lowering of costs and costs, and increasing the use of innovations. It is difficult to provide security because some countries have a non-competitive economy. The economy of Azerbaijan has been facing difficulties in implementing the transformation of the economy since 1992, taking 
into account national and economic security issues. Because it would not have been possible to prepare the economy directly for international relations, to join the external relations, and to regulate the foreign debt, the level of prices and the degree of tax burden. The level of budget deficit in each country should not exceed $20 \%$ in a year, and more than $10 \%$ for several consecutive years.

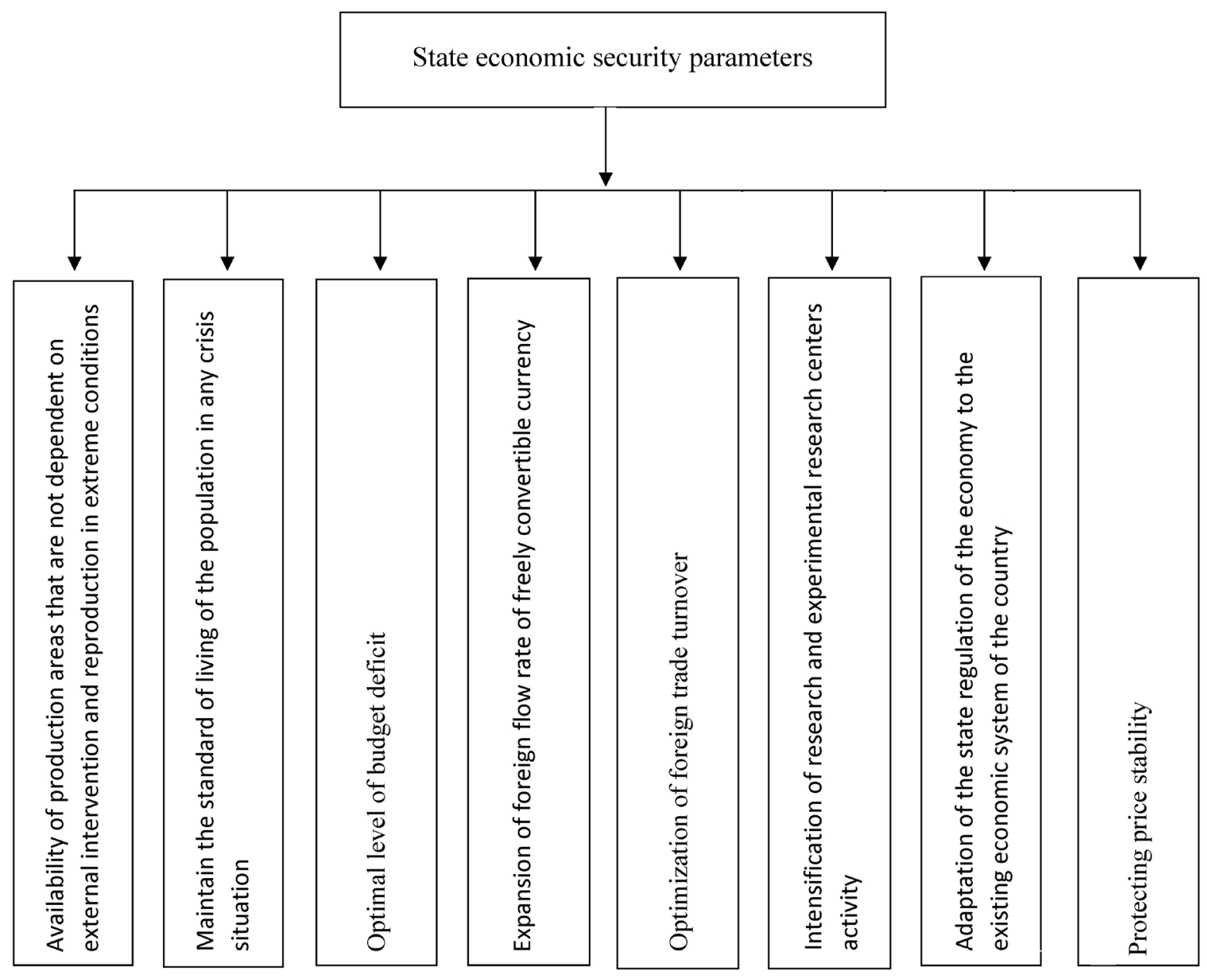

Figure 1.

Note: The image was compiled by the author on the basis of the existing economic conditions

It is necessary to increase the focus on the structure of the real sector in ensuring the economic security of Azerbaijan. Here, they can achieve achievements in improving the country's economic security by improving the structure of production, preventing deformities, optimizing macroeconomic proportions. In Azerbaijan, it is not just a matter of improving the quality of production, but also reorienting it to the restructuring. That's why it is a strategic line for attracting foreign investments to the country because of lack of financial resources.
One of the problems that poses an economic threat to Azerbaijan is the weakness of scientific and technical potential. This is due to the downturn in investment and innovation. It is beyond the ability to solve this problem without investing heavily in strategic areas of the national economy. However, as we have noted, Azerbaijan's natural resources, which are not analogous to the world, can allow this. This, in particular, depends on the use of natural factors in the country. It should be borne in mind that natural resources are infinite, and it is inevitable that there 
are negative aspects of trying to get out of it with intensive use. Therefore, control over the efficient use of natural resources is necessary and regulated.

Taking into account the participation of the Republic of Azerbaijan in international economic relations as one of the main economic risks, export balance is export oriented at the expense of raw materials, and food provision is provided by import. The formation and development of the national economy on a healthy basis, the formation of national ownership of the population is a factor which negatively affects the quality of life and slowing down the resolution of social problems. World practice shows that more than $20-25 \%$ of total consumption can be a threat to the country's independence if dependent on imports. This problem will also lead to the country's foreign exchange reserves. This is also a means of economic danger.

According to the State Customs Committee, exports of food products (including beverages and tobacco) will amount to $\$ 0.77$ billion in $2015, \$ 0.53$ billion in $2016 \$ 0.59$ billion in 2017 If imports of foodstuffs were $\$ 1.3$ billion in 2015, $\$ 1.34$ billion in $2016 \$ 1.57$ billion in 2017. As it is seen from the statistical data, exports of food products increased by 20.8 percent in 2015-2017, while exports declined by 23.4 percent.

Over $\$ 84.6$ million will be invested in Azerbaijan in 2017 hard wheat in the amount of $121.0 \mathrm{mln}$. soft wheat and meslin in the amount of $\$ 21.6$ million. USD corn was imported.

If we look at food balances in the country, it can be understood that in 2005, 1006,1 thousand tons of wheat total imports, while in 2016 this figure increased by 593.500 tons to 1599.600 tons. In 2017, it dropped to 1274.400 tonnes, or 2.6 percent of total imports.

Table 1 and Table 2 below provide information on the country's needs for some agricultural products and their dependence on imports.

Table 1.- Azerbaijan's major agriculture in 2010-2017 level of product supply (in percent)[3]

\begin{tabular}{|l|c|c|c|c|c|c|c|c|}
\hline $\begin{array}{l}\text { The name of } \\
\text { the product }\end{array}$ & $\mathbf{2 0 1 0}$ & $\mathbf{2 0 1 1}$ & $\mathbf{2 0 1 2}$ & $\mathbf{2 0 1 3}$ & $\mathbf{2 0 1 4}$ & $\mathbf{2 0 1 5}$ & $\mathbf{2 0 1 6}$ & $\mathbf{2 0 1 7}$ \\
\hline Grain Plants & 56.5 & 64.8 & 64.3 & 63.9 & 60.6 & 64.5 & 63.8 & 66.3 \\
\hline Potato & 100.5 & 101.6 & 98.2 & 97.6 & 89.7 & 89.1 & 85.5 & 89.2 \\
\hline $\begin{array}{l}\text { All kinds of } \\
\text { vegetables }\end{array}$ & 97.6 & 95.7 & 98.9 & 102.3 & 103.4 & 103.4 & 105.4 & 115.2 \\
\hline Fruit and berry & 107.8 & 116.8 & 125.7 & 121.8 & 120.1 & 113.7 & 116.4 & 122.4 \\
\hline Milk & 70.4 & 70.9 & 72.5 & 76.0 & 76.3 & 84.3 & 87.7 & 86.1 \\
\hline Beef & 95.5 & 88.0 & 92.6 & 86.3 & 87.7 & 91.8 & 93.5 & 86.3 \\
\hline Sheep meat & 99.7 & 99.8 & 98.5 & 97.7 & 97.9 & 99.3 & 98.7 & 98.0 \\
\hline Bird meat & 70.6 & 79.9 & 87.8 & 98.5 & 98.0 & 98.6 & 79.1 & 79.7 \\
\hline Eggs & 97.8 & 77.4 & 96.2 & 100 & 99.7 & 99.7 & 98.8 & 100.5 \\
\hline
\end{tabular}

As can be seen from the table, self-sufficiency with foodstuffs can not be considered as savvy. Thus, the level of self-sufficiency in potatoes in the republic, as well as the supply of livestock and poultry has been decreasing.

Analysis shows that potato imports have continued at an accelerated pace until 2016, an increase of more than fourfold in 2005 and totaling 191,200 tons in 2016. In 2017, slightly (by 11.7\%) it was 168.8 thousand tons. Potato exports have also made significant progress in 2017. Thus, the export of potatoes in 2005 amounted to 39.1 thousand tons, in 2010 it increased by two times to 69.9 thousand tons, in 2015 and 2016 it decreased twice to 36.7 and 38 respectively, Despite its 3,000 tonnes, in 2017 it has risen significantly (more than 1.5 times) to 57,700 tons. 
Import of all types of vegetable products in 2005 will be 24.300 tons, in 2010-84.900 tons, in 201542.0 thousand tons, in 2016-61.2 thousand tons, in 2017 and 45.9 thousand tons. There has been a decline in the dynamics of imports of vegetables over the past period. Import in 2017 was reduced to 40,000 tons in comparison with 2010. There is a significant increase in exports. Thus, export of all types of vegetables in 2017 amounted to 231.5 thousand tons in 2017, which is 5.1 times more than in 2005, 2010, 2015 and 2016, 4.1 times, 2.8 times and 1.8 times more.

While smaller amounts of livestock and dairy products are reimbursed from imports, substantial portion of poultry and livestock feed needs are provided through imports. This means that feeding animals in the country depend on foreign currency.

Table 2. - Level of dependence on imports by certain types of products in 2010-2017 (percent)[3]

\begin{tabular}{|l|c|c|c|c|c|c|c|c|}
\hline $\begin{array}{c}\text { The name of the } \\
\text { product }\end{array}$ & $\mathbf{2 0 1 0}$ & $\mathbf{2 0 1 1}$ & $\mathbf{2 0 1 2}$ & $\mathbf{2 0 1 3}$ & $\mathbf{2 0 1 4}$ & $\mathbf{2 0 1 5}$ & $\mathbf{2 0 1 6}$ & $\mathbf{2 0 1 7}$ \\
\hline Grain Plants & 43.5 & 35.2 & 35.7 & 36.1 & 39.4 & 35.5 & 36.5 & 33.7 \\
\hline Potato & 6.8 & 8.3 & 7.8 & 7.7 & 15.7 & 14.8 & 18.1 & 16.5 \\
\hline $\begin{array}{l}\text { All kinds of veg- } \\
\text { etables }\end{array}$ & 7.0 & 9.5 & 5.7 & 3.1 & 3.4 & 3.4 & 5.1 & 3.8 \\
\hline Fruit and berry & 22.4 & 12.3 & 10.1 & 4.9 & 3.6 & 9.6 & 12.6 & 12.7 \\
\hline Milk & 29.6 & 29.1 & 27.5 & 24.3 & 23.9 & 16.0 & 12.6 & 14.6 \\
\hline Beef & 5.5 & 12.9 & 8.9 & 14.8 & 13.2 & 8.8 & 6.6 & 13.8 \\
\hline Sheep meat & 0.3 & 0.2 & 1.5 & 2.3 & 2.1 & 0.7 & 1.3 & 2.4 \\
\hline Bird meat & 29.8 & 20.3 & 12.2 & 1.5 & 2.1 & 1.4 & 20.9 & 20.5 \\
\hline Eggs & 2.1 & 22.6 & 4.2 & 0.1 & 0.3 & 0.3 & 1.2 & 0.0 \\
\hline
\end{tabular}

Table 2 shows that the level of import dependence of cereals, potatoes and poultry is still high in 2010-2017.

The relative decline in imports of all types of flour in Azerbaijan was observed in this period, and thus the level of self-sufficiency was satisfactory (96 percent in 2017). The level of self-sufficiency in macaroni products decreased from 72.7 percent in 2010 to 48 percent in 2017. Significant progress has been achieved in the provision of cleaned rice and groats.

While sugar production in our country is high in sugar production, sugar production is not covered by local raw materials. This leads to a foreign exchange flow for imported raw materials. Looking at tea production, it can be seen that in the years 2010-2017, self-sufficiency of tea has dropped, as a result of which importivity has increased.

Proper customs policy pursued by the state primarily serves to ensure economic security of the country and protection of the domestic market. Cus- toms policy in foreign economic activity is mainly implemented by customs tariff regulation method. Developing its economy on the basis of market principles, our Republic takes important steps to deepen international integration, benefiting from the experience of developed countries and deepening mutual cooperation with different countries. In order to provide more favorable conditions for domestic production, to protect the country's economy from negative effects of external competition, as well as to protect the interests of foreign and local entrepreneurs, a number of customs tariff regulation methods have been implemented in our Republic, with the aim of creating healthy competition conditions for foreign economic activity participants, a number of work has been done by the company. This includes improving the application of taxes and duties, enhancing their efficiency, and improving the mechanism of their receipt in the state budget. Also, reduction of import customs duties on different groups, contrary to increase of duties on certain commodity groups in the 
country, increase of business relations with different countries, transfer of some goods to the simplified customs clearance system, etc. The solution of other issues has become an objective necessity.

As you know, customs tariffs are the only means of economic regulation in foreign trade relations that are applied in all countries, as well as in our country, covering all commodity groups. Customs tariffs play a major role in the effective regulation of imports and exports as well.

Another way to ensure economic security is the non-tariff regulation. At that time, foreign trade quota is applied, which is the limit on imports or exports.
Unlike the above-mentioned import duties, the use of quota will allow for more accurate import restrictions. For example, increasing import duties may result in an increase in the total amount of payments. However, this increase may not affect the amount of imports, but the quota implementation of the import can give positive effect if it is competing with the product on the domestic market.

In the modern era, our Republic has changed the tariffs sufficiently to ensure economic security based on all this. This gives the country owners the opportunity to direct domestic production to national production, namely Made in Azerbaijan brand.

\section{References:}

1. International Conference Materials Azerbaijan - After Independence, Qafqaz University - Baku 2003.$28 \mathrm{p}$.

2. Shakaraliyev A.Sh., Shakariyeva Z. A Foreign-economic activity regulation of tariffs, - Baku, 2006.425. - P. 62-63.

3. The State Statistical Committee of the Republic of Azerbaijan URL:http: www.stat.gov.az 
Muratova Shokhista,

$\mathrm{PhD}$ in Economics, the department of

Customs examination and classification of goods

Customs institute,

E-mail: shohista11@mail.ru

\title{
ROLE AND IMPORTANCE OF COMMODITY SCIENCE IN THE IMPLEMENTATION OF INNOVATIVE FOOD PRODUCTS
}

\begin{abstract}
The analysis of the formation of commodity flows in the food market is given; it is also shown that in modern conditions a special institute is needed to study consumer preferences and design innovative food products. The role of such an operator in the supply chain of goods in the food market should be assumed by the institute of commodity science.

Keywords: commodity science, innovative food products, consumer preferences; supply chains of goods.

Commodity science as a scientific discipline develops within the framework of a historically formed scientific paradigm on the basis of modern fundamental theoretical knowledge and is closely related to production technology, nutritional physiology, economics, and marketing [1]. In the study of the chemical composition, physical and chemical properties of goods, the processes occurring in them during storage, as well as in the development of methods of production, storage, including food canning, knowledge of physics, chemistry, microbiology and other basic sciences are used in commodity research.

This product is the material basis for trade. Communication commodity science with economic sciences (economic geography, economics of trade, organization of wholesale and retail trade, etc.) allows you to properly organize the study of demand, placing an industry order, keeping records of goods during its turnover, optimize the range, monitor the status of inventories in the wholesale and retail chains supply chain. The multi-factor character of the tasks facing commodity research requires a special systematic approach.

The system organization of commodity science will allow satisfying the widest needs of the population in high quality goods and services. Investigate

the commodity is necessary from the standpoint of a systematic approach. The systematic approach implies a methodological trend in science, the main task of which is to develop methods for the study and design of complex objects.

Commodity science, as a branch of human activity, has existed since the formation of commodityexchange relations in society. Already at the dawn of human history there was a need to develop a system of equivalence of goods, taking into account their consumer value. The development of such a system inevitably required the formation of a system of evaluation of goods on the basis of quality and quantity.

In the conditions of commodity-market relations, the system of interaction between various food market operators has changed dramatically. Currently, the process of forming the mechanism of innovative consumption, including foodstuffs, is intensively underway [2]. Separate elements of this mechanism are at various stages of formation, but the general trends of its development can be formulated already now. In general, any system that is at a fixed point of its evolutionary development is always affected by a range of factors acting on it. The vector of development of the system is the resultant force, which is a consequence of the balanced influence of
\end{abstract}


existing factors. As a rule, the main factors are factors that stimulate innovative development, and factors aimed at maintaining the achieved level (conservative factors).

As an example of a conservative, preserving for generations, the accumulated experience in catering can be considered the principle of organic nutrition [3]. According to this doctrine, rational nutrition is based on products obtained with minimal involvement of innovative technologies. This approach has a significant number of supporters, and the turnover of "organic food" products amounts to tens of percent of the total world food production. However, it may not take into account a number of factors that affect food raw materials, which for various reasons, the manufacturer cannot control, and which can have significant effects on the object of control. These factors can include the effects of various physical fields, climatic and other factors. At the same time, social factors influencing the quality of life (state of permanent stress, high intensity of labor, climatic and natural factors of psychological impact on the vital activity of a modern person) do not always guarantee adequate nutrition, organized on the principles of "organic foods".

Considering the arguments presented in the last 2-3 decades, the technology of food production has been developing with the ever-increasing influence of specialized and functional nutrition on it $[4 ; 5]$. This direction is being developed by the "trial and error" method, but the achieved level of innovative technologies in the field of specialized and functional nutrition allows making a conclusion about its unconditional prospects.The direction of specialized and functional nutrition is also heterogeneous and has a tendency of wide differentiation: from the ideas of a balanced mass food [5] to nutrigenomics [6], which takes into account the individual characteristics of an individual organism. The personal approach to nutrition is also due to the physiological and psychological characteristics of the perception of food, different sensory sensitivity to the same food objects [7].
In modern understanding, the term "quality of food products" describes not only the biological, physiological, energy and other types of product value, but also its ability to satisfy the most sophisticated, sometimes difficult to describe heuristic consumer characteristics [8].

One of the main objectives of merchandising in the current system of the balance of quality expectations and its real content is the development and implementation of technology to give products all new consumer qualities that not only meet the expectations of consumers, but also anticipate them.

The formulated task is not trivial, and requires the development of a new ideology for the formation of a food market. The main innovative feature of such a market is: on the consumer side, the presence of conscious demand for food products in accordance with individual (group) preferences; on the part of the institute of commodity science - the ability to adequately respond to the demands of society to meet consumer preferences in the present tense and in advance; on the industry side, the ability to quickly meet the identified consumer preferences in the form of innovative technologies and products.

Which element of this triad is limiting- determining the pace of introduction of innovative products?

A distinctive feature of modern industry is its greatly increased mobility. If in the 80's-90's of the last century, the acceptable depreciation rate of technological equipment was $12-14 \%$, which implied a 7-8-year period of its operation, today some enterprises reduce the time needed to upgrade equipment to 3-4 years. At the same time, of course, depreciation charges increase, ultimately affecting the retail price of goods.

The strategy of quickly updating the product range of products is justified. Thus, the industrial sector from a conservative link has become a link that can quickly respond to emerging market needs. The industry can quickly organize the production of almost any product and is ready to fulfill any order of the market, but it turned out that the procedure 
for forming such a kind of technical task is a difficult and extraordinary task.

Despite the increased mobility in the promotion of innovative products to the market, the industry still plays a subordinate role, as it is forced to focus on the technical task set by other social institutions [9; 10].

In the above triad of the main operators of the innovative food market, the consumer also plays the role of not the subject, but the object of application of new technologies. He is also unable to manage the process of innovative development of food technology. At best, an analysis of consumer behavioral mechanisms may reveal the level of consumer acceptability of food products, but not the vector of development of its consumer preferences. The concept of "consumer preferences" refers to the psychological and emotional sphere of assessing the quality of goods, and they can be formulated as a result of special technologies of heuristic expertise.

The only subject in the process of forming an innovative food market can only be a merchandising institute whose task is to identify consumer preferences in the form of a heuristic portrait of a product, the translation of heuristic characteristics into technological concepts and modes, and the development of technical specifications for the production of an innovative product for industry.

At the same time, a commodity expert should have broad knowledge and competences in all areas: identifying consumer expectations with their differentiation by age, social, sex, and regional groups; possession of a mathematical apparatus for an adequate assessment of the results of the examination; the transformation of the identified consumer expectations into physic-chemical concepts and technological semantic categories; the formation of "technical specifications" of the industry; organization of targeted delivery of products designed and manufactured to orders to the consumer through the wholesale and retail networks.
Identification and systematization of consumer preferences can be methodically implemented using a clustering procedure [11].

When implementing the clustering procedure, the principle of ensuring maximum information content should be observed. This principle assumes that the cluster parameters are formed in such a way that the amount of information about the described samples is maximum:

$$
I_{c l}=-\sum_{i=1}^{N_{d}} P_{i} \log P_{i} \rightarrow \max ,
$$

where $P_{i}$ is the probability of the sample belonging to the i-th cluster; $N_{c l}$ - the number of clusters.

Algorithms of cluster analysis are very diverse. These can be, for example, algorithms that implement a complete enumeration of combinations of objects, or carry out random partitions of a set of objects. At the same time, most of these algorithms consist of two stages. At the first stage, an initial breakdown of the set of objects into classes is carried out and a certain mathematical criterion of the quality of classification is given. Then objects are transferred from class to class until the criterion value ceases to improve. Such algorithms are widely used for fuzzy formulation of criteria for belonging.

The task of clustering samples is usually formulated under conditions of sufficient certainty of the criterion clustering base (the type, functional purpose, and vector of parameters defining consumer properties of samples are preset), and therefore, simplified algorithms for determining whether a sample belongs to a cluster can be used. A sign of the sample belonging to the formed cluster is the fulfillment of the condition:

$$
R_{q}=\frac{1}{n} \sum_{i=1}^{n} \sqrt{\left(x_{i}-x_{o i}\right)^{2}} \leq R_{t h r},
$$

where $R_{q}$ is the standard deviation of the sample characteristics from the average in the cluster; $x_{i}-$ technical characteristics of the sample (when clustering the samples, both quantitative and qualitative characteristics of the samples are used, the value $x_{i}=0$ is assigned to the qualitative characteristics 
of the samples if this characteristic is absent in the sample and $x_{i}=1$ if the characteristic is present); $x_{o i}$ is the average value of the $\mathrm{i}$-th technical characteristic in the analyzed set of samples; $R_{t h r}$ - the threshold value of the mean square deviation of the sample characteristics from the average in the cluster.

The choice of $R_{t h r}$ is carried out on the basis of an iterative procedure, based on the principle of maximum informative clustering. Clusters are allowed to form for the spectrum of $R_{t h r}$ values.

From the above list of tasks facing commodity research, it is clear that the commodity expert should take on the functions of the organizer and operator of the supply chain of innovative goods
[12]. Such product supply chains should contain functional, morphological and informational components $[13 ; 14]$.

A functional description is necessary to determine the place, role and assessment of the relationship of the supply chain to the external environment. The morphological component forms the idea of the structure of the supply chain, and the informational component consists in the formation of information content on the properties of the chain as a whole and its individual elements.

A schematic diagram of the movement of information and material flows in the design of new food products is shown in (figure 1).

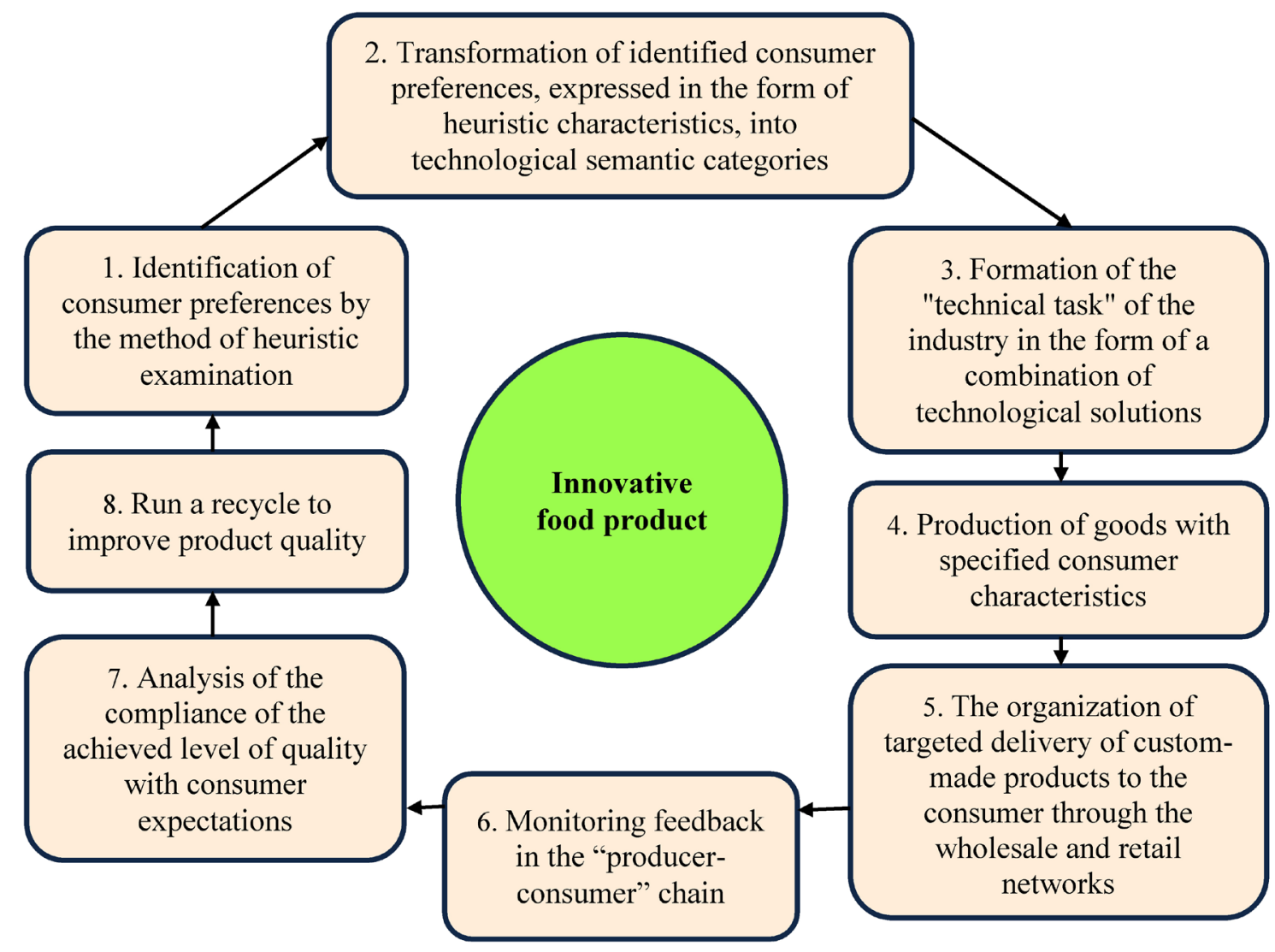

Figure 1. Formation of the chain of material and information flows in the design of innovative food products

As can be seen from the figure, the tasks of commodity science in the design of innovative food products are reduced not only to identifying consumer preferences and developing a new product project in the form of a "technical task", but also organizing an analysis of the effectiveness of the results achieved and measures to adjust the entire project. Thus, in the conditions of a developed market, the role of a merchandiser becomes key value. Commodity science should assume the function of the operator of 
the whole process of providing the population with innovative types of food, taking into account its diverse needs.

Each of these stages requires reflection and development of its own theoretical framework, including methodological, methodological, informational support. The underestimation of the role of commodity science and the lack of a systematic approach to its tasks in modern society can not only create unfavorable prerequisites for a real improvement in the quality of life of the population, but also create unfavorable prerequisites for the growth of consumption rates, and hence GDP in the whole country. Moreover, it is necessary to create conditions for enhancing the role of commodity science, giving this sector of the economy new functions, primarily in the area of developing a new culture and technology of consumption, which will inevitably lead to the rapid development of the consumer goods market, which is the locomotive of the national economy.

\section{References:}

1. Nikolaeva M.A. Theoretical foundations of commodity science: Textbook.-M.: Norma, 2008.

2. Andreev G.I., Tikhomirov V.A. and others. The economic mechanisms of enterprise management: Tutorial.- M.: Finance and Statistics, 2008.

3. Pan-European Agreement on Organic Production of Agricultural Products. - No. 2092/91 of June 24, 1991. (Council Regulation No 2092/91 of 24 June 1991 on organic production of agricultural products).

4. GOST R52349-2005. Food products. Functional food products. Terms and Definitions.

5. Doronin A. F., Shenderov B. A. Functional food.- M.: Granit, 2005.

6. Sean Astley. Research Scientist, Institute for Food Research, Norwich, UK.- Nutrigenomics: Specially selected food? / - URL:http://www.phdgate.net website.

7. Motherland T. G. Sensory analysis of food products: Textbooks for university students.-M.: Publishing Center "Academy", 2004.

8. Nikolaeva M.A. Commodity examination.- M.: Publishing house "Business literature”, 1998.

9. Lou Cohen. Quality Function Deployment: How to Make QFD Work for You.- Addison Wesley Longman.

10. Sidorenko Yu. I. The objectives of the commodity science of food products in a market economy / collection of reports I interdepartmental scientific and practical conference "Commodity, examination and technology of food products.” - M.: MGUPP Publishing Complex, 2008.

11. Andreev G. I., Tikhomirov V.A. and others. Evaluation of intellectual property: Ucheb.pos.- M.: Finance and Statistics, 2003.

12. Hendfield Robert B., Nichols Ernest L. (Jr.). Reorganization of supply chains. The creation of integrated systems of value formation / Per. from English - M.: Publishing house "Williams", 2003.

13. Andreev G. I., Ostapenko S. N. and others. Methodology of life cycle management of complex technical systems. - V. 4.- M.: VNIINS, 1997.

14. Andreev G. I., Tikhomirov V.A. and others. Models and methods of enterprise management in conditions of uncertainty: Tutorial.- M.: Finance and Statistics, 2006. 


\title{
Section 8. Economic theory
}

\author{
Mose Naftaly, \\ University of Eldoret, Kenya \\ E-mail:ngmoce@uoeld.ac.ke \\ Were Lawrence, \\ Jepchumba Irene, \\ Muthoni Jane, \\ Egerton University, Kenya
}

\section{DRIVERS OF GROWTH IN THE AGRICULTURAL SECTOR ON THE DEVELOPMENT PLAN}

\begin{abstract}
Agricultural sector contribute about $36 \%$ of the East African Community's Gross Domestic Product (World Bank, 2009), 80 per cent of the populace depend on agriculture directly and indirectly for food, employment and income, while about 40 million people in EAC (East African Countries) suffer from hunger and the agricultural sector still retains a lot of untapped potential, specifically for commercial farming. However, economic growth target for agriculture sector can be achieved by stimulating three factors; capital, labor and total productivity of capital and labor through R\&D. This study applied panel random effect model on EAC countries data, 2000-2014. Random effects regression results showed that all explanatory variables had a significant and positive relationship with the dependent variable. From the findings the study recommends: R\&D to be allocated more funds; and more research scientists and agricultural labourers to be employed in EAC.

Keywords: Agricultural Sector Growth, Labour, Capital, Research and Development, EAC, Economic Growth.

\section{Introduction}

Economic planning of economic decisions in the long-term accomplishes to directing and controlling the Economic development plans are formulation at the level and growth of a country's basic economic variables. Sector planning is performed rationale and relying on the quantitative variables and factors influencing growth tools, resources and economic potentials of each section, (macro and sector levels), in planning and formulation of in order to achieve development goals at the macro level. However,

studies have shown that the size of government methods is used (with statistics and data); one of these has significant effect on economic growth of the agricultural sector and labor productivity in agriculture. One of the important steps in the process of has a direct relationship with investment of the public planning (FAO [2]; Khaledi and Shirazi [6]; Sertoğlu et al., [14]).

Further, Matahir took a different stand on his study on the role of agriculture on growth and how it interplays with other sectors in the economy. Time se-
\end{abstract}


ries Johansen cointegration techniques was employed to investigate the non-causality relationship between agriculture and other sectors of Tunis. From their findings, it was posited that, policy makers should see agricultural sectors as vital tools in their analysis of inter-sectorial growth policies (Matahir, [8]).

Therefore, the actual investment in the agricultural sector are not limited to the tools of production, machinery and buildings; actually in the agricultural sector part of the earth, trees and livestock units are considered a type of capital. However, share of land and living capital lies in value added of agricultural sector and it is not just the result of employing labor and physical capital.

Labour productivity in East Africa has declined substantially due to labour contraction especially in Kenya and Tanzania. However, it has recovered substantially in Rwanda and Uganda. Given these trends the average yield for East Africa's major crops currently fall well below those elsewhere in Africa and even further below global levels. These trends in productivity growth have translated into poor overall agricultural growth rates in individual countries in East Africa and for the region as a whole.

\section{Literature Review}

Arrow [1] model regarded learning by doing as endogenous in the growth process. The theory hypothesised that at any moment of time, new capital goods incorporate all the knowledge then available based on accumulated experience, but once built, their productive deficiencies cannot be changed by subsequent learning. The theory showed that if the stock of labour is held constant, growth ultimately comes to a halt because socially very little is invested and produced. This was supported by Segura and Rodriguez [13] who said that learning is a product of experience (doing) that takes place during activity, since it usually occurs through the attempt to solve a problem. Rotheli [12] also supported this theory by saying that the observation by Arrow proved the capability of workers to improve their productivity by regularly repeating the same type of action. The increased productivity is achieved through practice, self perfection and minor innovations. However, Romer [11] criticised this model by saying that for technical reasons, the fact that this model could lead to sustained endogenous growth was not emphasised. Some researchers conducted research on the effect of $R \& D$ and other areas related to $R \& D$ on economic growth in different countries and regions. All of them have come up with different results hence they have been inconclusive.

\section{Methodology}

Levin, Lin and Chu [7] developed a unit root test for panel data. When the linear combination of the two variables is $\mathrm{I}(0)$, then the variables are said to be co integrated. Differencing leads to lose of long run relationship between variables and so co integration test is being conducted to check whether the variables have got long run relationship or not. Pedroni [10] developed a residual-based panel co integration test statistics based on within dimension and between- dimensions. To ascertain whether to employ fixed effects model or random effects model, the study conducted Hausman Test which was developed by Hausman [4]. The test basically tries to establish whether the error terms are correlated with the regressors, with the null hypothesis stating absence of such correlation. The basic panel regression equation was used to investigate the relationship between R\&D and agricultural sector growth. Further econometric estimation tests were carried out.

\section{Results and Discussion}

From regression result, for the case of agricultural capital, the coefficient is 0.12 and statically significant at 5\% level of significance. This implies that a one percent increase in agricultural capital leads to a $0.12 \%$ increase in agricultural sector growth (output). The result is positive and conforms to the conventional view. This could be because agricultural capital helps in faster facilitation of agricultural activities for example in faster tilling of land, faster planting, faster weeding, faster harvesting of crops, faster milking of cows, faster spraying of domestic 
animals and faster milling of grains hence helps to increase/improve the quality and quantity of agricultural products. In addition, it could be because transportation of the agricultural products or agricultural raw materials is made easier and faster to the markets, stores and factories. There could also be reduced wastage of agricultural products which may lead to increased productivity as raw materials could be easily transported to the factories for processing. The finding of this study on the effect of agricultural capital on agricultural sector growth is in agreement to the finding of $\operatorname{Kim}[5]$.

For the case of agricultural labour, the coefficient is 0.16 and statically significant. The positive relationship may be attributed to the presence of a healthy and energetic agricultural labour force who could actively participate in the various roles assigned to them like driving of tractors for tilling land, planting, weeding and harvesting and this could lead to increased agricultural productivity. The other factor that could have contributed to this positive relationship between agricultural labour force and agricultural output growth could be a good work environment for the agricultural labour force through better wages, provision of security and working tools, appropriate working hours, proper laws and regulations that were protecting their rights and which were being implemented and these could have prevented things like strikes and go-slows and instead boosted their morale in their work and hence increased agricultural output. In addition, the positive coefficient could have been because of the presence of trained, skilled and experienced agricultural labour force which implies that they had the capability to use the farm tools and equipment and were also well versed with the way the farm tools and equipments were being used in the production process and hence led to increased agricultural output. Further, the above finding agrees with the result of Kim [5].

From the regression results, the coefficient of agricultural R\&D expenditure is 0.85 and statically significant at $5 \%$. The endogenous growth theory says that $R \& D$ leads to increase in the stock of knowledge which in turn has got spill over effects hence leads to economic growth. This positive relationship could be because allocating funds for agricultural research leads to increased agricultural research which causes increased knowledge about high yielding crops, the invention of drought resistant crops which helped in preventing crop failures in the event of a drought, better ways of improving soil fertility which leads to increased yields, introduction of advanced machines in production which made the production process to go faster hence high quality and quantity of products within a short period of time. These advanced machines may include machines for tilling land like tractors, milking machines, harvesting machines and planting machines. Agricultural research and development could have also led to the discovery of crop and livestock diseases, what causes them, how they can be prevented and even a solution should they occur. This boosts crop productivity and hence increased agricultural growth. The positive and significant effect of agricultural $\mathrm{R} \& \mathrm{D}$ expenditure could have been as a result of proper dissemination of knowledge generated through agricultural $R \& D$ and thus increasing agricultural productivity in EAC. The above finding agrees with the previous studies of Pardy et al. [9]; and Gutierrez and Gutierrez [3].

\section{Conclusion and Recommendation}

Agricultural capital influenced agricultural sector growth positively and the influence was statistically significant. To accelerate this effect, the governments of EAC states should subsidize the cost of farm tools and equipment and also make loans easily accessible to farmers by lowering the interest rates to enable them acquire agricultural capital. Taxation on agricultural products that serve as raw materials to the agro-based industries should also be lowered to make raw materials easily available to these industries. Agricultural firms should also invest properly on farm tools and equipment and ensure that they are well serviced and maintained as these efforts will make the agricultural sector not to be capital deficient. 
Further, agricultural labour was found to influence agricultural sector growth positively and the influence was significant. To enhance this influence, the governments should subsidise health services for easy access and this will make people to be healthy and energetic and hence more productive in the agricultural sector especially the agricultural labour. In addition, the governments should ensure that there are laws in place that protect the rights of workers in terms of their minimum wage rates and the working hours and also ensure that the laws are adhered to and this will make workers productive as strikes and go slows will not be experienced when the laws are adhered to. Lastly, R\&D funding should be increased every year to facilitate agricultural R\&D. In addition, more agricultural research scientist should be trained and employed for serious agricultural research to be carried out. Also, the government should do more in disseminating the research result to farmers and agricultural institutions.

\section{References:}

1. Arrow K.J. Economic Welfare and the Allocation of Resources for Invention. In K. Arrow (Ed.) The Rate and Direction of Inventive Activity: Economic and social Factors. 1962.- P. 609-626. Princeton University Press.

2. FAO. Prospect for Food, Nutrition, Agriculture and Major Commodity Groups, Being an Interim Report on Agriculture.- Rome: FAO. 2006.

3. Gutierrez L., \& Gutierrez M. International R\&D Spillovers and Productivity Growth in the Agricultural Sector: A Panel Cointegration Approach. Department of Agricultural Economics: University of Sassasi,Italy. 2005.

4. Hausman J. Specification Tests in Econometrics. Econometrica,- No. 46. 1978.-P. 1251-1271.

5. Kim L. The Economic Growth Effect of R\&D Activity in Korea. Korea and the World Economy,Vol. 1.- No. 12.2009.- P. 25-44.

6. Khaledi K., \& Shirazi A. Estimates of Factors Affecting Economic Growth in the Agricultural Sector in the Fifth Development Plan of Iran. World Applied Sciences Journal, 22 (10): 2015.- P. 1492-1499.

7. Levin A., Lin C., \& Chu C. Unit Root Tests in Panel Data: Asymptotic and Finite-Sample Properties. Journal of Econometrics, 108, 2002.- P. 1-24.

8. Matahir H. The empirical investigation of the nexus between agricultural and industrial sectors in Malaysia. International Journal of Business and Social Science, 3(8), 2012.- P. 225-230.

9. Pardy P. G., Kang M., \& Elliott H. The Structure of Public Support for National Agricultural Research Systems: A Political Economy Perspective. Agricultural Economics,- Vol. 4.- No. 3. 2012.

10. Pedroni P. Crucial Values for Cointegration Tests in Heterogenous Panels with Multiple Regressors. Oxford Bulletin of Economics and Statistics,- No. 61. 1999.- P. 653-670.

11. Romer P. The Origins of Endogenous Growth, Journal of Economic Perspectives,- No. 8. 1994.- P. 3-22.

12. Rotheli T.F. Exogenous and Endogenous Growth, Journal of Political Economy,- No. 44. 1993. - P. 1-10.

13. Segura J, \& Rodriguez B. An Eponymous Dictionary of Economics: A Guide to Laws and Theories Named after Economists, Edward Elgar Publishing Limited: Chetanham. 2004.

14. Sertoğlu K., Ugural S., \& Beku V. The Contribution of Agricultural Sector on Economic Growth of Nigeria. International Journal of Economics and Financial Issues, 7(1), 2017. - P. 547-552. 
Shen Kenneth, The Wardlaw-Hartridge School, NJ Edison, NJ

E-mail: kenshen12.26@gmail.com

\title{
MAXIMIZING PROFITABILITY THROUGH MODEL SIMPLICITY AND CLUSTER ANALYSIS
}

\begin{abstract}
Machine-learning techniques were used to construct forecasting models of consumer credit risk. Using mimic data from consumer credit risk domain, binary logistic regression was used to build the models to predict the likelihood of default. The goal was to develop a model with as few predictors as possible, while not going lower than a concordant level of $65 \%$. This paper compares a 4-variable model and a 12-variable model based on simplicity and profitability. Using the selected model, cluster analysis was then performed to maximize the estimated profitability. The 4-variale model achieves a profit $\$ 122.340 .69$ on 1000 accounts. KS of the model is 0.542 . The 12 -variable model achieves profit $\$ 126.062 .48$ on 1000 accounts. KS of the model is 0.606 . The profit difference on 1000 accounts base is only $\$ 3.721 .79$. The Cluster 1 segment of 4 -variable model achieves profit $\$ 143.616 .62$, which is determinant as the best segment.
\end{abstract}

Keywords: Machine-learning, logistic regression, consumer credit risk, K-means model.

\section{Introduction}

While developing a product or service, a predictive statistical model is needed to maximize the profitability of a product or service. While a predictive statistical model should be as accurate as possible to predict the likelihood of default, a statistical model with too many predictors can also cost company both time and money. It takes time to collect data, so it is reasonable to assume that it would cost additional time if a more complex model was selected. Data collection also costs money, and the more variables there are in a model, the more data would need to be acquired. The purposes of this paper are to explore the cost of simplicity and how a predictive statistical model can be maximized to increase a company's profitability.

\section{Method}

\subsection{Logistic Regression}

- Define binary variable to predict the likelihood of default using the binary response variable GoodBad;

- Before building the models, random samples taken from the dataset were partitioned into two independent files: a training dataset and a validation dataset;

- Models were developed and tested using the backward selection option in Proc Logistic procedure;

- Through the process of model development and validation, 4-variale and 12-varaible models were selected for comparison.

\subsection{Model Comparison}

- ROC curves, Gains tables and KS test were generated for each model;

- Data was classified into four categories ERROR1, ERROR2, VALID1 and VALID2 using a selected cutoff probability;

- Profitability reports were generated for each model using a profitability function.

2.3 Cluster Analysis using K-means model

- Data was standardized using Proc Stdize procedure with range method;

- K-means was used to partition data into 3 clusters. The K-means method identifies 3 centroids, and then allocates every data point 
to the nearest cluster, while keeping the centroids as small as possible;

- Canonical discriminant analysis was performed using Proc Candisc procedure;

- The most profitable subpopulation to target was identified.

\section{Result}

\subsection{4-Variable Model}

A logistic regression model using 4-varible was established as below (See Table 1).

Table 1.- Analysis of maximum likelihood estimates for 4 -variable model

\begin{tabular}{|c|l|c|c|c|c|c|}
\hline \multicolumn{7}{|c|}{ Analysis of Maximum Likelihood Estimates } \\
\hline Parameter & \multicolumn{1}{|c|}{ Parameter Description } & DF & Estimate & $\begin{array}{c}\text { Standard } \\
\text { Error }\end{array}$ & $\begin{array}{c}\text { Wald } \\
\text { Chi-Square }\end{array}$ & Pr > ChiSq \\
\hline Intercept & & 1 & -0.05250 & 0.25820 & 0.04 & 0.8389 \\
\hline $\mathbf{X 1}$ & $\begin{array}{l}\text { Utilization of all revolving } \\
\text { bankcard trades }\end{array}$ & 1 & 0.00058 & 0.00025 & 5.23 & 0.0223 \\
\hline $\mathbf{X} 2$ & $\begin{array}{l}\text { Highest utilization on any } \\
\text { single bank revolving trade }\end{array}$ & 1 & 0.00099 & 0.00039 & 6.46 & 0.0111 \\
\hline $\mathbf{X} 3$ & $\begin{array}{l}\text { Total collection/charge off/ } \\
\text { Repossession dollars within } \\
\text { 12 months }\end{array}$ & 1 & 0.00005 & 0.00002 & 10.57 & 0.0011 \\
\hline & $\begin{array}{l}\text { Percent of trades never de- } \\
\text { linquencies or derogatory }\end{array}$ & 1 & -0.03620 & 0.00310 & 136.36 & $<.0001$ \\
\hline
\end{tabular}

\subsection{4-Variable Model Performance}

The gains table (See Table 3 ) is tabulated as be-

All 4 variables are significant in the level of 0.05 . low that KS achieves 0.542 . The model can achieve percent concordant of 68.8 and Area Under Curve of 0.688 (See Table 2 and Figure 1).

Table 2.- Association of predicted probabilities and observed for 4-variable model

\begin{tabular}{|l|c|l|c|}
\hline \multicolumn{4}{|c|}{ Association of Predicted Probabilities and Observed } \\
\hline \multicolumn{4}{|c|}{ Responses } \\
\hline Percent Concordant & 68.8 & Somers' D & 0.377 \\
\hline Percent Discordant & 31.1 & Gamma & 0.378 \\
\hline Percent Tied & 0.2 & Tau-a & 0.147 \\
\hline Pairs & 2.082 .730 & c & 0.689 \\
\hline
\end{tabular}

Table 3.- Gains table for 4-variable model

\begin{tabular}{|c|c|c|c|c|c|c|c|c|c|}
\hline Decile & $\begin{array}{c}\text { De- } \\
\text { fault }\end{array}$ & $\begin{array}{c}\text { Cum } \\
\text { Default }\end{array}$ & $\begin{array}{c}\text { Mean } \\
\text { Default }\end{array}$ & $\begin{array}{c}\text { Cum } \\
\text { Default } \\
\text { Rate }\end{array}$ & $\begin{array}{c}\text { Default } \\
\text { Capture } \\
\text { Rate }\end{array}$ & $\begin{array}{c}\text { Min } \\
\text { Score }\end{array}$ & $\begin{array}{c}\text { Max } \\
\text { Score }\end{array}$ & $\begin{array}{c}\text { Mean } \\
\text { Score }\end{array}$ & KS \\
\hline $\mathbf{1}$ & $\mathbf{2}$ & $\mathbf{3}$ & $\mathbf{4}$ & $\mathbf{5}$ & $\mathbf{6}$ & $\mathbf{7}$ & $\mathbf{8}$ & $\mathbf{9}$ & $\mathbf{1 0}$ \\
\hline 1 & 80 & 80 & 0.327 & 0.327 & 0.439 & 0.172 & 1.000 & 0.356 & 0.366 \\
\hline 2 & 46 & 127 & 0.190 & 0.259 & 0.693 & 0.082 & 0.170 & $\mathbf{0 . 1 1 6}$ & 0.533 \\
\hline 3 & 20 & 147 & 0.080 & 0.199 & 0.801 & 0.049 & 0.082 & 0.062 & 0.542 \\
\hline 4 & 6 & 153 & 0.025 & 0.155 & 0.835 & 0.038 & 0.049 & 0.043 & 0.470 \\
\hline 5 & 9 & 162 & 0.038 & 0.132 & 0.885 & 0.031 & 0.038 & 0.034 & 0.416 \\
\hline
\end{tabular}




\begin{tabular}{|c|c|c|c|c|c|c|c|c|c|}
\hline $\mathbf{1}$ & $\mathbf{2}$ & $\mathbf{3}$ & $\mathbf{4}$ & $\mathbf{5}$ & $\mathbf{6}$ & $\mathbf{7}$ & $\mathbf{8}$ & $\mathbf{9}$ & $\mathbf{1 0}$ \\
\hline 6 & 15 & 177 & 0.062 & 0.120 & 0.969 & 0.029 & 0.031 & 0.029 & 0.399 \\
\hline 7 & 3 & 180 & 0.011 & 0.105 & 0.984 & 0.027 & 0.029 & 0.028 & 0.307 \\
\hline 8 & 2 & 182 & 0.009 & 0.093 & 0.996 & 0.026 & 0.027 & 0.026 & 0.212 \\
\hline 9 & 1 & 183 & 0.003 & 0.083 & 0.999 & 0.025 & 0.026 & 0.025 & 0.108 \\
\hline 10 & 0 & 183 & 0.000 & 0.074 & 1.000 & 0.025 & 0.025 & 0.025 & 0.000 \\
\hline Total & 183 & 183 & 0.074 & 0.074 & 1.000 & 0.025 & 1.000 & 0.074 & 0.542 \\
\hline
\end{tabular}

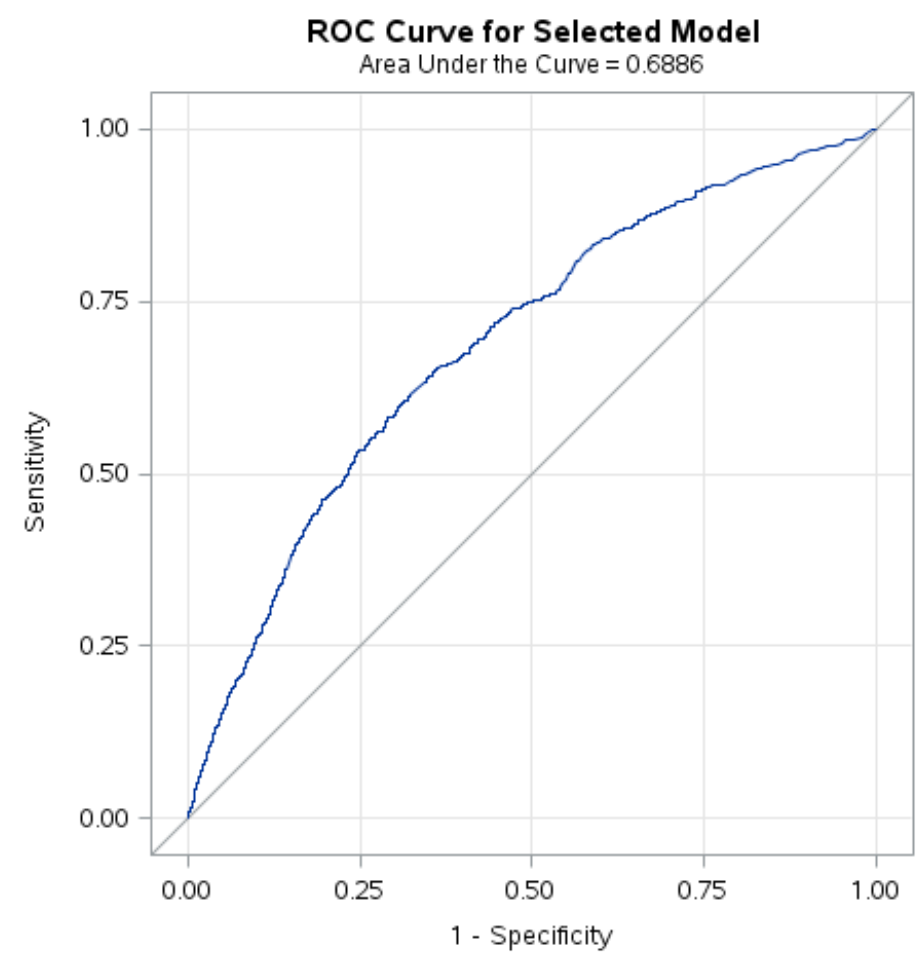

Figure 1. ROC curve for 4-variable model

\subsection{4-variable Model Profitability Calculation}

If it is assumed when the predict default probability is greater than a given number, it would be a bad account; otherwise, it would be a good account. GoodBad can be assigned to the scored data. An ex- ample here is if the cutoff probability of 0.116 from the mean score at the second decile is used, the model development data can be classified into 4 categories: ERROR1, ERROR2, VALID1 and VALID2. The profitability can be listed in the below table (See Table 4).

Table 4. - Profitability table for 4-variable model

\begin{tabular}{|l|c|c|c|c|}
\hline \multicolumn{1}{|c|}{ Outcome type } & Percentage & n & Profit & Profit per 1000 account \\
\hline ERROR1 & $17 \%$ & 571 & $\mathbf{( \$ 1 0 5 . 8 3 3 . 1 4 )}$ & $\mathbf{( \$ 1 8 5 . 3 4 7 . 0 1 )}$ \\
\hline ERROR2 & $10 \%$ & 327 & $\$ 0.00$ & $\$ 0.00$ \\
\hline VALID1 & $9 \%$ & 295 & $\$ 0.00$ & $\$ 0.00$ \\
\hline VALID2 & $64 \%$ & 2078 & $\$ 506.009 .54$ & $\$ 243.507 .96$ \\
\hline Total & $100 \%$ & 3271 & $\$ 400.176 .39$ & $\mathbf{\$ 1 2 2 . 3 4 0 . 6 9}$ \\
\hline
\end{tabular}

Here ERROR1 is a category in which the accounts are assigned to be good. However, the ac- counts are actually bad, so $\mathbf{\$ 1 0 5 . 8 3 3 . 1 4}$ is lost on 571 accounts. It is equivalent that $\mathbf{\$ 1 8 5 . 3 4 7 . 0 1}$ is lost on 
1000 accounts. ERROR2 is a category in which the accounts are assigned to be bad, but they are actually good accounts, so money is neither lost nor earned; VALID 1 is a category in which the accounts are assigned to be bad and the accounts are actually bad, so a lost is successfully avoided; VALID2 is a category in which the accounts are assigned to be good and they are actually good accounts, so $\$ 506,009.54$ is successfully earned on 2078 accounts. It is equiva- lent that $\$ 243.507 .96$ is earned on 1000 accounts. This is a winning business in which $\$ 400.176 .39$ can be earned on the total 3271 accounts; equivalently, $\$ 122.340 .69$ can be earned on 1000 accounts.

\subsection{4-Variable Model K-means Cluster and Profitability}

Customers are clustered into 3 clusters. A SAS procedure FASTCLUS using K-means method was performed.

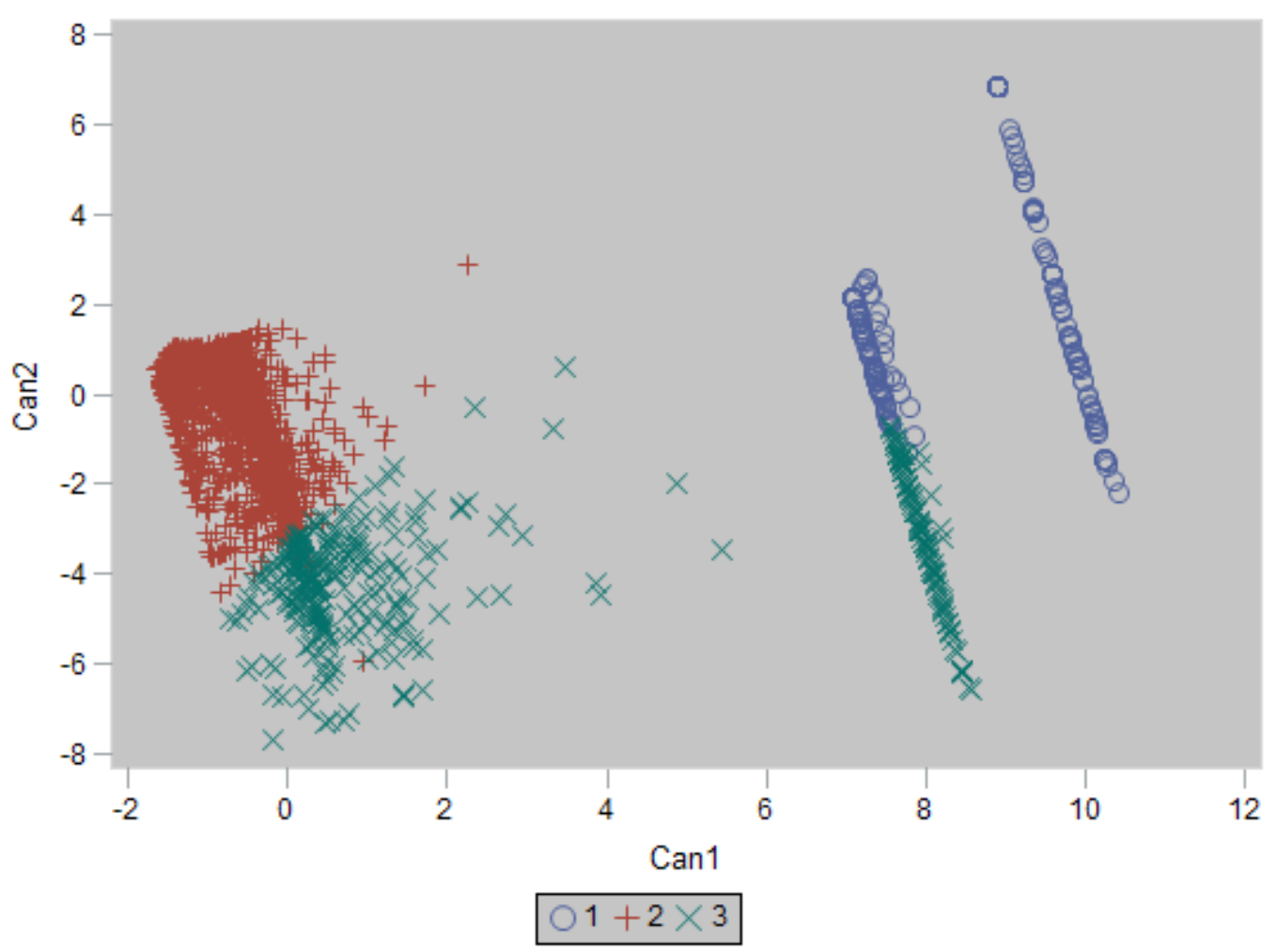

Figure 2: Plot of canonical variables identified by cluster value

The resulting plot (See Figure 2) illustrates the spatial separation of the clusters calculated in the FASTCLUS procedure. Here blue circles represent the Cluster1, which is assumed to be the best segment in profit.
If the same cutoff probability of 0.116 at the second decile is applied to the Cluster 1 segment, there is the profitability table (See Table 5) below. Higher profit can be achieved. The Cluster 1 is determined as the best segment.

Table 5. - Profitability table for Cluster 1 segment

\begin{tabular}{|l|c|c|c|c|}
\hline \multicolumn{1}{|c|}{ Outcome type } & Percentage & $\mathbf{n}$ & Profit & pper1000 \\
\hline ERROR1 & 0.1972097 & 523 & $\mathbf{( \$ 9 6 . 8 9 3 . 0 7 )}$ & $\mathbf{( \$ 1 8 5 . 2 6 4 . 0 0 )}$ \\
\hline ERROR2 & 0.0343137 & 91 & $\$ 0.00$ & $\$ 0.00$ \\
\hline VALID1 & 0.0286576 & 76 & $\$ 0.00$ & $\$ 0.00$ \\
\hline VALID2 & 0.739819 & 1962 & $\$ 477.764 .34$ & $\$ 243.508 .84$ \\
\hline Total & 1 & 2652 & $\$ 380.871 .27$ & $\mathbf{\$ 1 4 3 . 6 1 6 . 6 2}$ \\
\hline
\end{tabular}




\subsection{2-Variable Model}

A logistic regression model using 12-varible was established as below (See Table 6).

Table 6. - Analysis of maximum likelihood estimates for 12-variable model

\begin{tabular}{|c|c|c|c|c|c|c|}
\hline \multicolumn{7}{|c|}{ Analysis of Maximum Likelihood Estimates } \\
\hline \multirow{2}{*}{ Parameter } & \multirow{2}{*}{ Parameter Description } & \multirow{2}{*}{ DF } & \multirow{2}{*}{ Estimate } & Standard & Wald & \multirow{2}{*}{ Pr $>$ ChiSq } \\
\hline & & & & Error & Chi-Square & \\
\hline Intercept & & $\mathbf{1}$ & -1.63090 & 0.38640 & 17.81 & $<.0001$ \\
\hline $\mathbf{X} \mathbf{1}$ & $\begin{array}{l}\text { Utilization of all revolving } \\
\text { bankcard trades }\end{array}$ & 1 & 0.00138 & 0.00032 & 19.16 & $<.0001$ \\
\hline $\mathbf{X} 2$ & $\begin{array}{l}\text { Highest utilization on any sin- } \\
\text { gle bank revolving trade }\end{array}$ & 1 & 0.00716 & 0.00170 & 17.66 & $<.0001$ \\
\hline $\mathbf{X} 3$ & $\begin{array}{l}\text { Total collection/charge off/ } \\
\text { repossession dollars within } 12 \\
\text { months }\end{array}$ & 1 & 0.00006 & 0.00002 & 10.45 & 0.0012 \\
\hline $\mathbf{X} 4$ & $\begin{array}{l}\text { Percent of trades never delin- } \\
\text { quencies or derogatory }\end{array}$ & 1 & -0.01380 & 0.00441 & 9.82 & 0.0017 \\
\hline $\mathbf{X 5}$ & $\begin{array}{l}\text { Trades open greater than or } \\
\text { equal to 1-year payment ratio }\end{array}$ & 1 & -0.01310 & 0.00435 & 9.11 & 0.0025 \\
\hline X6 & Inquiries in last 6 months & 1 & 0.08310 & 0.02800 & 8.83 & 0.003 \\
\hline $\mathbf{X} 7$ & $\begin{array}{l}\text { Aggregate utilization of revolv- } \\
\text { ing trades }\end{array}$ & 1 & 0.00777 & 0.00270 & 8.31 & 0.0039 \\
\hline $\mathbf{X 8}$ & $\begin{array}{l}\text { Aggregate credit limit on re- } \\
\text { volving trades }\end{array}$ & 1 & 0.00000 & 0.00000 & 7.44 & 0.0064 \\
\hline X9 & $\begin{array}{l}\text { Number of } 30 \text { DPD trades re- } \\
\text { ported within } 2 \text { years }\end{array}$ & 1 & 0.16170 & 0.06240 & 6.71 & 0.0096 \\
\hline $\mathbf{X 1 0}$ & $\begin{array}{l}\text { Number of } 30-180 \text { DPD with- } \\
\text { in } 6 \text { months }\end{array}$ & 1 & 0.07540 & 0.02930 & 6.62 & 0.0101 \\
\hline $\mathbf{X 1 1}$ & $\begin{array}{l}\text { Number of revolving trades } \\
\text { with high utilization }\end{array}$ & 1 & 0.03660 & 0.01600 & 5.24 & 0.0221 \\
\hline $\mathbf{X 1 2}$ & $\begin{array}{l}\text { The average credit limit of } \\
\text { trades }\end{array}$ & 1 & -0.00001 & 0.00001 & 4.94 & 0.0263 \\
\hline
\end{tabular}

\subsection{2-Variable Model Performance}

All 12 variables are significant in the level of 0.05 . The model can achieve percent concordant of
72 and Area Under Curve of 0.72 (See Table 7 and Figure 3).

Table 7.- Association of predicted probabilities and observed for 12-variable model

\begin{tabular}{|l|c|c|c|}
\hline \multicolumn{4}{|c|}{ Association of Predicted Probabilities and Observed } \\
\hline \multicolumn{4}{|c|}{ Responses } \\
\hline Percent Concordant & 72 & Somers' D & 0.44 \\
\hline Percent Discordant & 28 & Gamma & 0.44 \\
\hline Percent Tied & 0 & Tau-a & 0.171 \\
\hline Pairs & 2.082 .730 & c & 0.72 \\
\hline
\end{tabular}




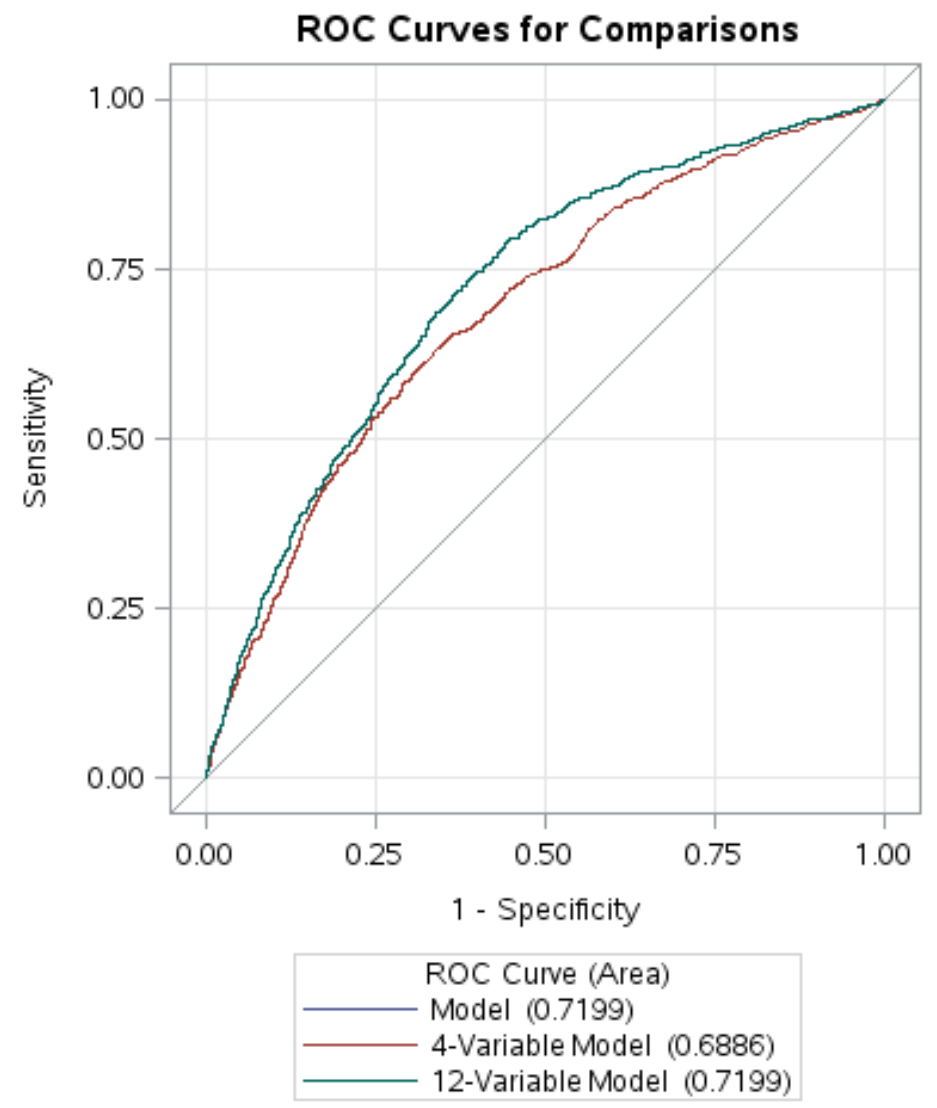

Figure 3. ROC curve for comparison

The ROC curve above shows that there is very little difference between probabilities of the two models, especially when 1-Specificity is between
0.25 and 0.75 . Will this difference be a big impact on profitability? The gains table (See Table 8) will be explored further, tabulated as below.

Table 8.- Gains table for 12-variable model

\begin{tabular}{|c|c|c|c|c|c|c|c|c|c|}
\hline Decile & Default & $\begin{array}{c}\text { Cum } \\
\text { Default }\end{array}$ & $\begin{array}{c}\text { Mean } \\
\text { Default }\end{array}$ & $\begin{array}{c}\text { Cum } \\
\text { Default } \\
\text { Rate }\end{array}$ & $\begin{array}{c}\text { Default } \\
\text { Capture } \\
\text { Rate }\end{array}$ & $\begin{array}{c}\text { Min } \\
\text { Score }\end{array}$ & $\begin{array}{c}\text { Max } \\
\text { Score }\end{array}$ & $\begin{array}{c}\text { Mean } \\
\text { Score }\end{array}$ & KS \\
\hline 1 & 97 & 97 & 0.398 & 0.398 & 0.532 & 0.207 & 1 & 0.400 & 0.467 \\
\hline 2 & 42 & 139 & 0.170 & 0.284 & 0.760 & 0.101 & 0.207 & $\mathbf{0 . 1 4 3}$ & 0.606 \\
\hline 3 & 17 & 156 & 0.067 & 0.211 & 0.851 & 0.062 & 0.101 & 0.079 & 0.595 \\
\hline 4 & 12 & 168 & 0.050 & 0.171 & 0.918 & 0.038 & 0.062 & 0.047 & 0.560 \\
\hline 5 & 7 & 175 & 0.029 & 0.143 & 0.957 & 0.023 & 0.038 & 0.030 & 0.493 \\
\hline 6 & 4 & 179 & 0.015 & 0.121 & 0.977 & 0.015 & 0.023 & 0.019 & 0.408 \\
\hline 7 & 1 & 180 & 0.004 & 0.105 & 0.982 & 0.010 & 0.015 & 0.012 & 0.305 \\
\hline 8 & 1 & 181 & 0.004 & 0.092 & 0.988 & 0.006 & 0.010 & 0.008 & 0.203 \\
\hline 9 & 2 & 183 & 0.008 & 0.083 & 0.999 & 0.003 & 0.006 & 0.005 & 0.108 \\
\hline 10 & 0 & 183 & 0.001 & 0.074 & 1 & 0.000 & 0.003 & 0.002 & 0.000 \\
\hline Total & 183 & 183 & 0.074 & 0.074 & 1 & 0.000 & 1 & 0.074 & 0.606 \\
\hline
\end{tabular}


The Gains and Lift charts show only a small advantage of the 12 -variable model over the simpler one. KS achieves 0.606 .

\subsection{2-variable Model Profitability Calculation}

Similar to 4-variable model profitability calculation, when the predict default probability is greater than a given number, it would a bad account. Other- wise, it would be a good account. GoodBad can be assigned to the scored data. For example, if the cutoff probability of 0.143 from the mean score at second decile is used, the model development data can be classified into 4 categories: ERROR1, ERROR2, VALID1 and VALID2. The profitability is listed in the below table (See Table 9).

Table 9. - Profitability table for 12 -variable model

\begin{tabular}{|l|c|c|c|c|}
\hline Outcome type & pct & n & Profit & pper1000 \\
\hline ERROR1 & 0.16631 & 544 & $\mathbf{( \$ 9 8 . 4 2 7 . 9 0 )}$ & $\mathbf{( \$ 1 8 0 . 9 3 3 . 6 5 )}$ \\
\hline ERROR2 & 0.0963008 & 315 & $\$ 0.00$ & $\$ 0.00$ \\
\hline VALID1 & 0.0984408 & 322 & $\$ 0.00$ & $\$ 0.00$ \\
\hline VALID2 & 0.6389483 & 2090 & $\$ 510.778 .27$ & $\$ 244.391 .52$ \\
\hline & 1 & 3271 & $\$ 412.350 .37$ & $\mathbf{\$ 1 2 6 . 0 6 2 . 4 8}$ \\
\hline
\end{tabular}

Here ERROR1 is a category in which the accounts are assigned to be good. However, the accounts are actually bad, so $\mathbf{\$ 9 8 . 4 2 7 . 9}$ is lost on 544 accounts. It is equivalent that $\mathbf{\$ 1 8 0 . 9 3 3 . 6 5}$ is lost on 1000 accounts; ERROR2 is a category in which the accounts are assigned to be bad but they are actually good accounts, so money is neither lost nor earned; VALID1 is a category in which the accounts are assigned to be bad and they are actually bad accounts, so a loss is successfully avoided; VALID2 is a category in which the accounts are assigned to be good and the accounts actually good accounts, so $\$ 510.779 .27$ is successfully earned on 2090 accounts. It is equivalent that $\$ 244.391 .52$ is earned on 1000 accounts. This is also winning business in $\$ 412.350 .37$ is earned on the total 3271 accounts; equivalently, \$126.062.48 can be earned on 1000 accounts.

\section{Discussion}

The profit difference on 1000 accounts base is $\$ 3.721 .79$. It appears the 12 -variable model has a little advantage over the 4-variable model. However, the cost in term of time and money also needs to take into consideration. Using 4-variable model or 12 -variable model would depend on how much it could cost in complexity when the number of predictors is increased from 4 to 12 .

\section{Conclusion}

The research paper built two logistic models in predicting the likelihood of default. Two models were evaluated and compared based on concordance, AUC, KS, simplicity, and profitability. No recommendation is provided on which model is a better choice to a company, but the final profitability that each model can give is calculated. It will depend on the cost and incremental complexity to implement the models. The analysis also finished an unsupervised clustering process, targeting the most profitable cluster segment.

\section{References:}

1. Credit Default Risk Prediction. Available at: URL:https://repods.io/en/blog/Credit-default-risk-prediction

2. Modern Machine Learning Algorithms: Strengths and Weaknesses. Available at: URL:https://elitedatascience.com/machine-learning-algorithms 
3. Peng C. J., Lee K.L., Ingersoll G. M. An Introduction to Logistic Regression Analysis and Reporting. The Journal of Educational Research, 96(1),- P. 3-14.

4. Fawcett T. An introduction to ROC analysis [J]. Pattern recognition letters, 2006; 27(8): 861-874.

5. Stokes M., Davis C. S. Categorical Data Analysis Using the SAS System, SAS Institute Inc., 2001.

6. SAS $/$ STAT $^{\circledast} 15.1$ User's Guide the FASTCLUS Procedure. Available at URL:https://support.sas.com/ documentation/onlinedoc/stat/151/fastclus.pdf 


\section{Contents}

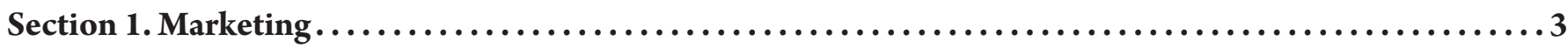

Xueyi Rui

SERVICE MARKETING RESEARCH BASED ON SOSTAC

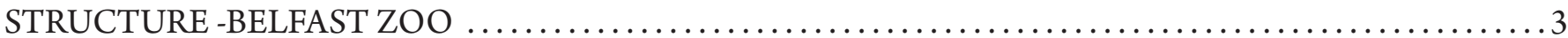

Section 2. Management.$\ldots \ldots \ldots \ldots \ldots \ldots \ldots \ldots \ldots \ldots \ldots \ldots \ldots \ldots \ldots \ldots \ldots \ldots \ldots \ldots \ldots \ldots \ldots \ldots \ldots$

Chornyi Oleh

IMPROVING INNOVATIONS: BETWEEN EU AND UKRAINE $\ldots \ldots \ldots \ldots \ldots \ldots \ldots \ldots \ldots \ldots \ldots \ldots \ldots \ldots$

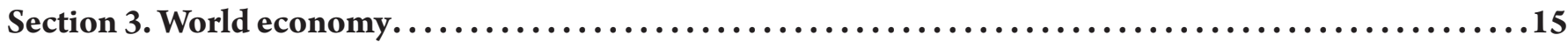

Abdullaev Turgut Nizami

PROSPECTS FOR COOPERATION BETWEEN THE ADB AND AZERBAIJAN TO

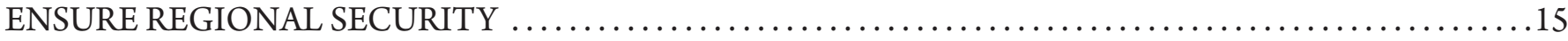

Borisik Olga Viktorovna

MULTI-FACETED DEVELOPMENT OF EURASIAN ECONOMIC INTEGRATION IN

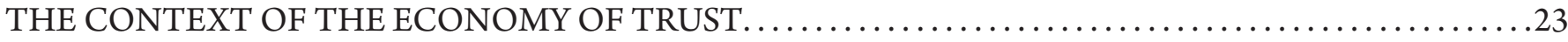

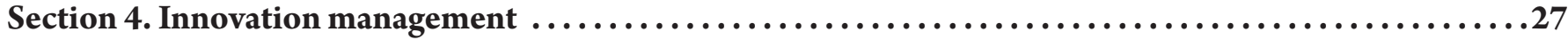

Kuznetsova Valentina Petrovna, Vardamatskaya Ludmila Petrovna,

Tropinova Elena Aleksandrovna, Radchenko Yulia Yurjevna

POSSIBLE SOLUTIONS OF IMPLEMENTING BLOCKCHAIN

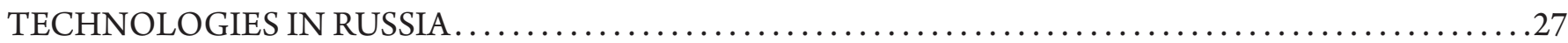

Section 5. Labour economics ...................................................

Karimova Minura Haji

SOME ECONOMIC ASPECTS OF THE IMPROVEMENT OF THE USE OF MATERIAL-

TECHNICAL PRODUCTION RESOURCES IN AGRICULTURE $\ldots \ldots \ldots \ldots \ldots \ldots \ldots \ldots \ldots \ldots \ldots \ldots \ldots \ldots$

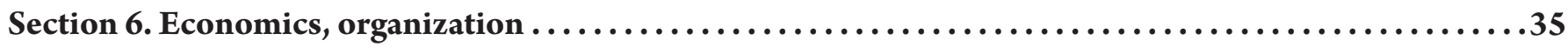

Ivanova Snezhana

PROSPECTS OF RUSSIAN-SOUTH KOREAN ECONOMIC COOPERATION AND

ANALYSIS OF WORLD MARKETS

Syaparman, Sri Suwitri, Etty Sosilowati, Hartuti Purnaweni

SUPPORTING AND RESTRICTING FACTORS OF CORPORATE SOCIAL

RESPONSIBILITY (CSR) PROGRAM OF POLICY IMPLEMENTATION

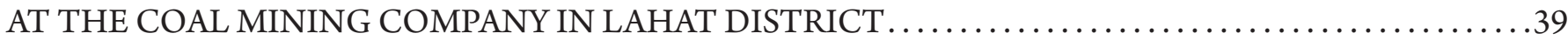

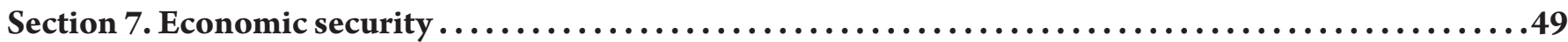

Dadashova Jala Bayram Qizi

INFLUENCE OF FOREIGN TRADE RELATIONS ON PROVISION OF AZERBAIJAN'S

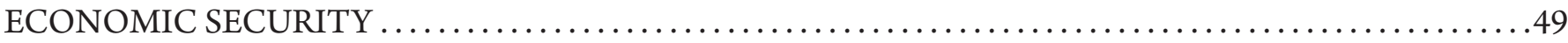

Muratova Shokhista

ROLE AND IMPORTANCE OF COMMODITY SCIENCE IN THE IMPLEMENTATION

OF INNOVATIVE FOOD PRODUCTS 
Section 8. Economic theory

.60

Mose Naftaly, Were Lawrence, Jepchumba Irene

DRIVERS OF GROWTH IN THE AGRICULTURAL SECTOR

ON THE DEVELOPMENT PLAN . .

.60

Shen Kenneth

MAXIMIZING PROFITABILITY THROUGH MODEL SIMPLICITY AND CLUSTER ANALYSIS .64 
